Portland State University

PDXScholar

6-1-1967

\title{
Social exchange in private family day care arrangements
}

\author{
Gerald Wesley Perry \\ Portland State University \\ Elizabeth Margaret Bergman \\ Marian Alayne Demas \\ William Everett Lowther \\ Eleanor Elizabeth Milne
}

See next page for additional authors

Follow this and additional works at: https://pdxscholar.library.pdx.edu/open_access_etds Let us know how access to this document benefits you.

\section{Recommended Citation}

Perry, Gerald Wesley; Bergman, Elizabeth Margaret; Demas, Marian Alayne; Lowther, William Everett; Milne, Eleanor Elizabeth; and Rankin, Sarah Milligan, "Social exchange in private family day care arrangements" (1967). Dissertations and Theses. Paper 415.

https://doi.org/10.15760/etd.415

This Thesis is brought to you for free and open access. It has been accepted for inclusion in Dissertations and Theses by an authorized administrator of PDXScholar. Please contact us if we can make this document more accessible: pdxscholar@pdx.edu. 


\section{Author}

Gerald Wesley Perry, Elizabeth Margaret Bergman, Marian Alayne Demas, William Everett Lowther, Eleanor Elizabeth Milne, and Sarah Milligan Rankin 


\section{AN ABS TRACT OF THE THESIS OF}

$\frac{\text { GERALD WESLEY PERRY, et al. for the }}{\text { (Name of student) }}$ presented on $\frac{\text { MASTERS }}{\text { (Degree) }}$
$\frac{\text { in MaCIAL WORK 23, 1967 }}{\text { (Major) }}$ (Date)

Title: SOCIAL EXCHANGE IN PRIVATE FAMILY DAY CARE

Abstract approved:

ARRANGEMENTS

A study of social exchange between working mothers and their sitters was based on a sample of terminated family day care arrangements in Portland, Oregon (1966-67). The sample, provided by the Multnomah County Public Welfare Commission and the Day Care Exchange Project of northwest Portland, consisted of the arrangements of 27 mothers and 23 sitters.

Review of the literature on family day care revealed a paucity of research on the relationship between mothers and sitters in such arrangements. The purpose of the study was to test the hypothesis that continuity of a family day care arrangement is a function of the independent variables of satisfaction with and dependence on the arrangement. Respondents were interviewed in relation to three phases of their family day care arrangement: formation, mainte:nance, and rermination. Likert-type attitude scales and 
semi-structured interview schedules were developed.

Findings partially confirmed the hypothes is. Using Guttman scale analysis, a scalar relationship was found associating low dependence with high satisfaction. The mothers who showed low dependence and high satisfaction tended to have arrangements of longer duration. 


\section{A PPROVED:}

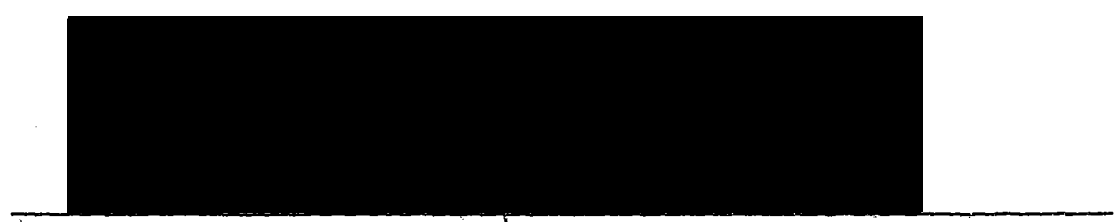

Associate Professor of Social Work
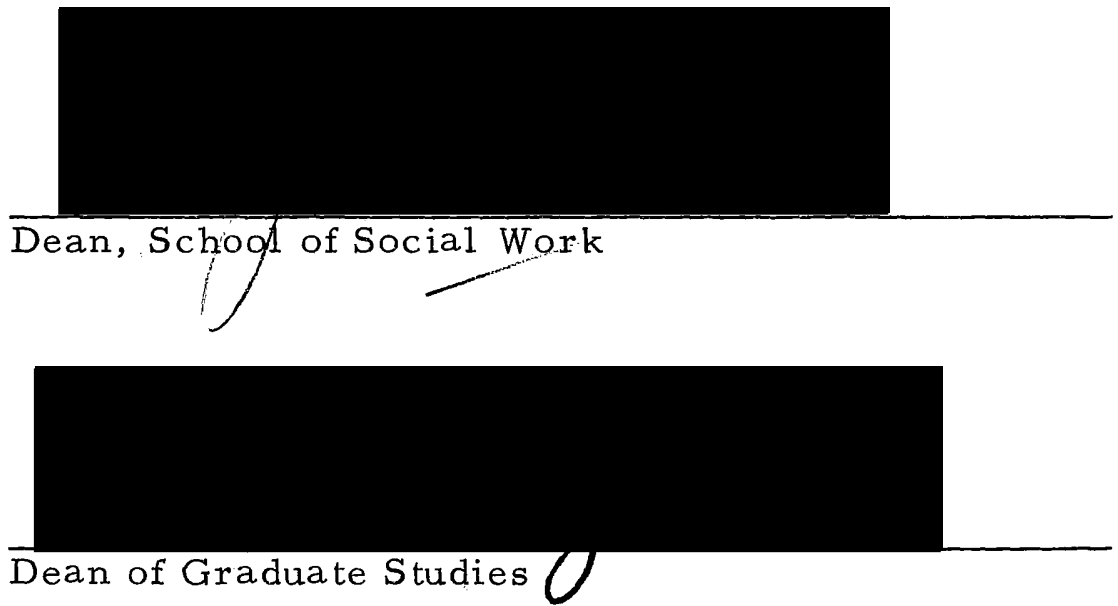

Date thesis is presented May 23, 1967

Typed by Illa W. Atwood for Gerald Perry, et al. 
Social Exchange in Private Family

Day Care Arrangements

by

Gerald Wesley Perry

William Everett Low ther

Elizabeth Margaret Bergman

Eleanor Elizabeth Milne

Marian Alayne Demas

Sarah Milligan Rankin

\author{
A THESIS \\ submitted to \\ Portland State College
}

in partial fulfillment of

the requirements for the

degree of

Master of Social Work

June 1967 


\section{ACKNOWLEDGEMENTS}

The members of this group project wish to express their thanks and appreciation to the many people and the two agencies who assisted in this study. For their help in securing the samples and their advice and support we are particularly indebted to Gordon Gilbertson, Administrator, Multnomah County Public Welfare Commission; to John Burch, Assistant Administrator, Multnornah County Public Welfare Commission; to Lowis G. Hahn, Project Consultant, Multnomah County Public Welfare Commission; to Mrs. Alice Collins, Project Director, Day Care Exchange Project; and to Miss Eunice Watson, Day Care Consultant, Day Care Exchange Project. We are grateful to the numerous caseworkers at the Multnomah County Public Welfare Commission who helped us in selecting a sample from that agency. We are indebted to the mothers and sitters who participated in this study and to Mrs. Ruth Wild, who typed the initial draft of this study.

We particularly wish to thank Mrs. Gerald W. Perry for making available to us the personal notes and reference materials of her late husband.

Finally, our special thanks and appreciation go to the three members of the thesis committee; Merwyn Greenlick, Lecturer in Sociology and Research Director, Kaiser Foundation; John M. 
Whitelaw, Assistant Professor of Social Work; and Arthur C.

Emlen, Associate Professor of Social Work and our Research

Project Director. Not only did Dr. Emlen teach, guide, and support us through every phase of this research project but his enthusiasm and dedication to creative, original, and disciplined thinking was a source of inspiration without which this study could not have been completed. 


\section{TABLE OF CONTENTS}

I. INTRODUCTION

Page

Rationale: Broad Aims of Study 1

Terminology 5

Focus, Scope and Specific Research Objectives 5

The Sample 8

The Hypothesis 11

II. REVIEW OF THE LITERATURE AND THEORETICAL BACKGROUND OF THE STUDY 14

Review of the Literature on. Child Care 14

Review of the Literature on Social Exchange 24

Theoretical Hypothesis of the Study 27

Summary 31

III. METHODOLOGY 33

Introduction $\quad 33$

Method of Data Collection and Scale Construction 36

Evaluation of the Scales 46

Data Analysis $\quad 50$

Method of Collecting the Sample $\quad 51$

IV. THE MOTHERS $\quad 59$

Introduction $\quad 59$

Characteristics of the Sample $\quad 60$

Characteristics of the Last Arrangement 62

Maintenance Behavior: Whose Responsibility? 64

Termination of the Last Arrangement 66

Sources of Role Satisfaction and Role Dependence 68

Satisfaction with the Last Arrangement 76

Analysis of Data $\quad 80$

Findings on the Relationship between Mothers.'

Dependence, Satisfaction, and the Continuity

of the Family Day Care Arrangement 86

$\begin{array}{ll}\text { Summary } & 88\end{array}$

$\begin{array}{ll}\text { V. THE SITTERS } & 91\end{array}$

Introduction and Review of the Literature 91

$\begin{array}{ll}\text { Characteristics of the Sample } & 94\end{array}$

Characteristics of the Last Arrangement 97 
TABLE OF CONTENTS (continued)

Maintenance Behavior

Page

Termination of the Arrangement

101

The Independent Variables

103

Findings

105

114

VI. SUMMARY AND IMPLICATIONS 120

Implications for Practice

124

Implications for Fur ther Research

128

Conclusion

132

BIBLIOGRA PHY

134

APPENDICES

143

Appendix A

144

Appendix B

152

Appendix $C$

159

Appendix D

165

Appendix E

171 


\section{LIST OF TABLES}

Page

I. Relationships Between the Scales for the Independent Variables

II. Reliability of the Scales

III. Distribution of Scale Scores

IV. Duration of the Arrangement by Scale Scores

V. Personal Characteristics of Mothers

VI. Income Levels

VII. Orientation of Mothers Toward Maintenance of Relationship with the Sitter

VIII. Summated-Rating Scale of Mothers' Role Satis faction (Mothers' RS)

IX. Frequency of Mothers' Agreement with Items Showing High Role Satisfaction

X. Frequency of Mothers' Agreement with Items Showing Low Role Satisfaction

XI. Summated-Rating Scale of Mothers' Role Dependence (Mothers' RD)

XII. Mothers' Role Dependence 75

XIII. Mothers' Role Freedom " 76

XIV. Summated-Rating.Scale of Mothers' Satisfaction with the Last Arrangement (Mothers' LAS)

XV. Non-Discriminating LAS Items for the Mothers

XVI. Items Related to Certain Aspects of the Last Arrangement (Mothers' LAS)

XVII. Mothers' Role Satisfaction and Role Freedom: 


\section{LIS T OF TABLES (continued)}

$\underline{\text { Page }}$

XVIII. Mothers' Work Role Dependence: Scalogram A 85

XIX. Mothers' Work Role Dependence: Scalogram B 86

XX. Duration of Arrangement by Scale Type on the Scalogram of Mothers Satisfaction and Role Freedom

XXI. Simplified Presentation of Table XX

XXII. Mothers'Accommodation Orientation by Work Role Dependence

XXIII. Summated-Rating Scale of Sitters' Satisfaction with the Last Arrangement (Sitters' LAS)

XXIV. Sources of Satisfaction for Sitters

XXV. Summated-Rating Scale of Sitters' Role Dependence (Sitters' RD)

XXVI. Sources of Role Dependence for Sitters

XXVII. Summated-Rating. Scale of Sitters' Satisfaction (Sitters' RS)

XXVIII. Sources of Role Satisfaction for Sitters'

XXIX. Sitters' Satisfaction and Role Freedom: A Guttman'Scale

XXX. Mothers' Day Care Preferences: A Guttman Scale

XXXI. Mothers' and Sitters' Paired Satisfaction and Role Freedom: A Gutman Scale

XXXII. Duration of Arrangement by Scale Type on the Scalogram of Mothers' and Sitters ' Paired Satisfaction and Role Freedom 


\section{SOCIAL EXCHANGE IN PRIVATE FAMIL,Y \\ DAY CARE ARRANGEMENTS}

\section{CHAPTER I}

\section{INTRODUCTION}

This report describes an exploratory study of the social behavior of a special sample of working mothers and their babysitters in making, maintaining, and terminating a family day care arrangement. The study is limited in scope to a single type of child care arrangement--private family day care; that is, child care arrangements in which a child goes into the home of a non-relative "sitter."

\section{Rationale: Broad Aims of the Study}

As the phenomenon of the working mother has become an increasingly commonplace feature of the American scene, concern for the welfare of the children of these mothers should keep pace. Attention has been accorded the effects of such maternal employment on all of the family members and on their interpersonal relationships (Nye \& Hoffman, 1963). When in-home care is not available for the pre-school child, leaders in the child welfare field tend to recommend the use of licensed day care and group facilities under the auspices of the social work profession. Frequently, family day care is ignored in a tendency to equate day 
care only with care given in day care centers. In a lay article appearing in the November, 1966 is sue of Today's Health entitled "When a Mother Works," the section devoted to child care plans completely ignored the family day care system as a child care possibility, while evaluating all others.

Yet, despite the child welfare field's tendency to recommend officially organized day care programs, statistics concerning the child care arrangements of working mothers point to the prevalence of unsupervised, privately made family care arrangements as the type of care most likely to be used by mothers who turn outside the home for child care. Of the 3.8 million children under six years of age whose mothers were employed, $78 \%$ are cared for at home or by relatives, $6 \%$ in group day care centers, $1 \%$ by themselves, and $15 \%$ are in family day care (Child Care of Nation's Working Mothers, 1966). Thus over half a million children under six were cared for in someone else's home by a non-relative during all or part of the mother's working hours. The number of working mothers with children under 14 has doubled between 1950 and 1964, and increased four hundred percent since 1940 (Burke, 1966). There does not appear to be any evidence that this trend is discontinuing.

On the contrary, popular literature such as Betty Friedan's best seller, The Feminine Mystique, contributes to the pressure on American mothers of all ages to obtain paid employment. The 
press gives wide circulation to statements such as President Johnson's remarks at the Seventh Annual Federal Women's Award; ". . America is finally beginning to use the full range of all its talent but (presently employed women) represent only a fraction of the woman power that should be doing useful work" (The Oregonian, March 17, 1967). On the low end of the economic scale, the Department of Health, Education, and Welfare has augmented this pressure by promoting legislation and money appropriations designed to train mothers receiving public assistance for employment which would enable them to become self-supporting.

Many mothers work from choice and are committed to a career which produces sufficient income to make employment economically attractive. Their earnings in many cases can provide a wider choice of child care systems, especially if their earnings are supplemental to the incomes of the families as a whole.

On the other hand, wornen who work from necessity, either as heads of household or because the family needs the money, often encounter the problem of inequity in pay for women in our society (Fleming, 1967). Their money for child care is limited and they are obliged to consider this factor in making arrangements for their children. The sample for the present study included many working mothers whose ability to produce an adequate income through employment is marginal, as well as other mothers whose family 
incomes were more adequate.

An increasing number of employed mothers, then, make a type of child care arrangement the characteristics of which remain largely unknown. The most extensive survey of day care arrangements was that conducted by the Child Welfare League of America (Ruderman, 1965); yet the data reported deals almost exclusively with officially organized day care services.

The chief purpose in undertaking this study therefore was to contribute to the scant body of knowledge regarding the working mother's child care arrangements. Private family day care was selected because of the one half million children under six receiving this care. An attempt was made to identify particular aspects of the system which were desirable and some which might lend themselves to modification with or without social work intervention. The intent was to clarify what was valuable in these arrangements and determine in what way, if any, these systems might be improved. In 1965 Florence Ruderman, Director of the Child Welfare League of America's Day Care Project, wrote:

We need to know a great deal more about the various kinds of informal care that millions of children now receive, so that we may have an informed basis on which to evaluate some current assumptions about the preferability of individual, family, or in-home care. (Ruderman, 1965, p. 213) 


\section{$\underline{\text { Terminology }}$}

The term "sitter" has come into general usage to refer not only to individuals who go into the child's home to give care, but also to the women who give family day care in their own homes to children brought to them. Both givers and users of this kind of child care refer to this position as "the sitter, "and in the present study it was decided to conform to the terminology of the study respondents rather than to use some other general term such as "day care giver," "day care mother," "foster family day care mother, "or "mother substitute." Some of these terms found in the child welfare literature suggest connotations that are not found in the attitudes of the women themselves who perform the roles in question. They seem to prefer the simple word "sitter" which minimizes the significance of the care giving role in contrast with the child welfare terminology which emphasizes the idea of substitute mothering. Perhaps the designation "sitter" is more acceptable to the working mothers than to their sitters but this language custom is now prevalent.

\section{Focus, Scope and Specific Research Objectives}

The only detailed information about these "unsupervised" family day care arrangements that seems to be available has come 
from two sources. The present research may be seen in relation to these two studies:

(1) a survey by Perxy (1961) in which relatively stable substitute child care arrangements were found, as well as a general attitude of satisfaction with the arrangements. The satisfaction reported, however, was a global evaluative attitude of the working mothers inferred by Perry from an apparent contentment and lack of complaints. This study did not attempt to measure satisfaction in the terms of its various sources in the relationship and circumstances of the arrangement.

(2) the Day Care Exchange Project, a demonstration project by the U. S. Children's Bureau and conducted under the auspices of the Portland, Oregon.Community. Council (Collins, 1966). This project, after an attempt to assess the quality of care given in family day care arrangements, became increasingly aware of the number of arrangements that do not last. In a sample of terminated arrangements $*(N=45)$ the median duration of arrangements was two weeks (Collins, 1966).

* It should be pointed out that a sample from the universe of terminated arrangements may be expected to have shorter durations than a sample such as Perry's which is from the universe of current arrangements. Also the Day Care Exchange sample is only from the universe of family day care arrangements. 
Discontinuity of care, then, emerged as the significant problem for private family day care and, therefore, was taken as the dependent variable to be accounted for in the present study.

The assumption was that extreme discontinuity is apt to have an adverse effect on the child and therefore to have a negative effect on all concerned in the arrangement. The discontinuity, in turn, discourages the sitter from continuing to give care.

For the purposes of this study no attempt was made to consider the quality of care given the children, rather the concern of the study was the mothers' and sitters' evaluations of the arrangements .

The two independent variables--degree of satisfaction with and degree of dependence on the family day care arrangement-were chosen as a way of identifying the significant sources of rewards and costs of making and maintaining the arrangement and of translating these into measurable items that would tap the valuations of participants in the arrangements.

The interest in family day care arrangements focused on the instability of such arrangements, which is a problem noted by the Day Care Exchange Project of Northwest Portland (Collins, 1966). Continuity (number of weeks duration) of the arrangement, therefore, was taken as the dependent variable for the study with the aim 
of investigating conditions associated with short-lived or longlas ting arrangements.

Thus, the basic unit of study was the family day care arrangement which was conceived as a behavioral system of social exchange between two women: the working mother and the sitter. For these women the arrangement would have values deriving from diverse sources such as the personal relationships, the benefits to the child, the convenience, the benefits of working, and in addition, the monetary exchange. The choice of independent variables, then, was based on the belief that exploration of the diverse costs and rewards of the arrangement to the two women who made it would provide an understanding of the crucial determinants of continuity of the ar rangement.

\section{The Sample}

The sample included 27 working mothers and 23 sitters. Of these there were 20 pairs of mothers and sitters for whom paired data on the same arrangement were obtained. In all the study included 35 family day care arrangements for 69 children.

This sample was collected from two agencies, the Multnomah County Public Welfare Commission and the Day Care Exchange Project of Nor thwest Portland. The criteria for inclusion in the sample limited respondents to those who had recently terminated a 
private family day care arrangement which had been necessitated either by the mother's employment, or by her participation in an educational program that had as its specific objective the subsequent employment of the mother. It was anticipated that arrangements of this second type would be found in the sample from the welfare department.

With the decision to include these mothers in the sample, the decision was also made to have them respond to questions that had a specific reference to "working," in terms of their feelings or attitudes based upon past work experience, if any, and in terms of their anticipated experiences in the role of a working mother. In this way all respondents would have a somewhat similar frame of reference.

The Multnomah County Public Welfare Commission views its elf as having a responsibility to help develop and maintain financial independence for those recipients of public assistance who diagnostically may be expected to achieve such a goal. For a woman who is also a mother, such a goal cannot be achieved in a socially accepted manner unless she is able to make and maintain child care arrangements which will meet the needs of her children, and thus enable her to achieve the role of a working mother.

Apart from the effects that unstable child care arrangements may have on a child, unstable arrangements may also affect the 
mother's ability to perform a work role, or to prepare herself for a work role through vocational training.

The agency serving this group of mothers was selected as a source from which our sample could be obtained. In addition to questions of expediency and availability, as locating family day care arrangements is a difficult methodological problem (Ruderman, 1965 the decision to include public assistance recipients in the sample was based upon several considerations.

Not only do recipients of public assistance represent a special group, but they are people whose life situations are of special interest to the social work profession.

The welfare department also was interested in learning more about this group. Committed to a policy of vocational rehabilitation and employment of public assistance recipients, including mothers who would need child care arrangements, the agency was aware that the stability--and to some extent the success of a vocational training program or job placement--would be adversely affected by instability in a child care arrangement.

In addition, including welfare recipients in the sample would provide a group in which many mothers felt under pressure to make and maintain a child care arrangement as a necessary aspect to becoming a working, earning member of society. This pressure would not only be from the community and from the agency, but 
pressure from themselves as they subscribe to the norms of society (Briar, 1966).

Unlike the welfare sample in which arrangements were located through the mothers, an additional sample was obtained through the Day Care Exchange Project, a neighborhood project which has contact with sitters.

In the Day Care Exchange Project a social worker maintains contact with a network of women, who, in addition to giving child care themselves, perform a special kind of neighboring role in helping their neighbors make child care arrangements. These women are called "Day Care Neighbors." By identifying these women, the Day Care Exchange Project has developed a system for locating and making contact with the target population of this study. This is no mean accomplishment, for it has been a way to locate a sample of a group that has been peculiarly unavailable (Ruderman, 1965C).

The samples, though obtained from different sources, both came from the universe of terminated family day care arrangements of working mothers or mothers preparing to work.

\section{The Hypothes is}

The working theoretical hypothesis of the study was that continuity of the arrangement is a function of the net value of the 
arrangement as evaluated by mothers and sitters. Two kinds of valuations were conceived:

(1) satisfaction (or dissatisfaction) with any aspect of the arrangement, such as its convenience, benefits for the child, liking for the sitter (or mother), the benefits of being a working mother, or the financial arrangements.

(2) dependence on the arrangement by virtue of restricted alternatives to the arrangement as perceived by the actors in the system; e.g., "I simply can't afford to quit work" (work role dependence), "I have to take what I can get in a sitter" (user role dependence), or "I have never asked for a child's removal" (sitter role dependence).

Specific research objectives included:

(1) developing attitude scales to measure the degree of satisfaction with the arrangement and the degree of dependence on the arrangement.

(2) testing the validity of the scales by assessing their consistency with semi-structured interview data about the interaction processes involved in making, maintaining, and terminating the family day care arrangement.

(3) testing the empirical hypothesis that these scales for the independent variables would be associated with the number of weeks' duration of the arrangement. 
It is important to point out that the research placed emphas is on the evaluative attitudes of mothers and sitters. What is significant, according to this approach, is not, for example, the adjustment of the child per se, but the degree of satisfaction or dissatisfaction felt by the mother and sitter arising from the adjustment of the child. Likewise, what is important is the felt convenience of the arrangement, the perception of preferred alternatives, the felt necessity of and incentive for working, and the subjective feeling of liking for another person.

Measurements of the mothers' and sitters' valuations of their arrangements, relationships, and relevant life circumstances, then, were adopted as an approach in the belief that it would be useful as a basis for further study and for social work practice to discover:

(1) what matters to mothers, or to sitters, and

(2) whether what matters to them makes any difference in their behavior as determinants of continuing a family day care arrangement.

Subsequent chapters will describe how these ideas were investigated, what results were learned, and what implications they have for social work practice and for further study. 
CHAPTER II

\section{REVIEW OF THE LITERA TURE AND THEORETICAL BACKGROUND OF THE STUDY}

This chapter develops a theoretical perspective for the study of private family day care arrangements. A review of the research literature on day care, maternal employment, and maternal separation/deprivation reveals little that deals specifically with family day care. Therefore, attention is turned to literature on social interaction for theoretical guidelines that might lead to fruitful study of how mothers and sitters make, maintain, and terminate that special kind of social relationship which is referred to in this study as a private, family day care arrangement.

\section{Review of the Literature on Child Care}

The need for an exploratory study that breaks new ground finds justification in a survey of the existing day care literature. Although recent socio-economic trends have drawn attention to the need for day care, social work, as well as the other helping professions (notably medicine, psychology and education) have given this topic little professional attention.

Day care was first included in the program for the National Conference of Social Work in 1919 (Collins, 1966)--nearly fifty 
years ago. In the intervening years, however, social work, as a profession, while recognizing day care as a legitimate concern, was reluctant to accept it as an area of social work intervention. Some of this reluctance may have been based on the conviction of profes sionals that mothers ought not to work--a conviction which is only now undergoing change in view of more recent research indicating that maternal employment in itself may not be so detrimental to children as had been thought earlier (Seiden, 1965; Siegel, et al. , 1959; Stolz, 1960). The large number of women who went to work during the war years--when maternal employment was considered a necessary and even patriotic gesture--also necessitated a change in the thinking of professionals.

It might be assumed that the rapid growth of nurseries and day care centers during these years would contribute much to research and professional literature on day care; yet a search of the literature does not bear out this as sumption. Literature on day care is inextricably linked to literature on maternal employment. The present study relied, to a large extent, on the work of Nye and Hoffman, The Employed Mother in America (1963) for a survey of the literature on day care prior to 1962. Although this study is exhaustive, only one article (Perry, 1961) deals with the subject of substitute child care which the employment of 3.6 million mothers of children under the age of 14 may be presumed to necessitate. 
The Perry study, in Nye and Hoffman, which deals dixectly with child care, contains only six bibliographical references; of those six, two date back to 1943. Other studies in Nye and Hoffman which deal with the effect of maternal employment on children are devoted to studies of nursery schools and deprivation, attention to age, sex, and other demographic variables. These authors concerned themselves with symptomatic behavior of children of working mothers without considering the type of substitute care the children receive during their mothers' absences from home.

A survey of the literature from 1962 through 1966 bore out the reluctance of the helping professions to accept day care as a legitimate sphere of professional examination. The HEW report of Abstracts and Demonstration Projects in Social Welfare and Related Fields (1966) lists 14 references to day care. Of these, four deal with the mentally and physically handicapped (an area of study which has evidently been considered "legitimate" by the profession for a number of years), five with migrant families, two with personnel training and licensing and three with survey and cost analysis. Only one of these deals in any way with family day care and that one is limited to a study of the scope of day care problems in New York City.

The Selected and Annotated Bibliography on Day Care, edited by Alice Merriam, and published in 1965, has nine references to 
family day care; two of these are Children's Bureau pamphlets and one is an editorial from a Hackensack, New Jersey newspaper reviewing these pamphlets.

A survey of the indexes of the three major social work jour nals - -Social Cas ework, Social Work, and Social Service Review-netted no references to day care in the years covered. Several other bibliographical indexes were surveyed; notably the Index Medicus which references such professional journals as Child Welfare, Children, Child Development as well as other medical and psychological journals; PAIS which contains among others Social Work, Social Service Review, and Journal of Marriage and Family Living; the Smith College Studies, Education Index, KWIC Index,

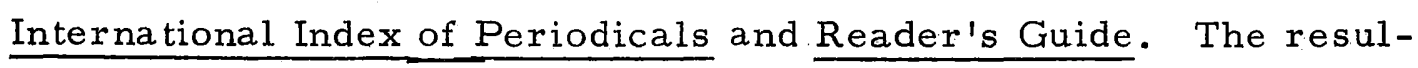
tant references gleaned from these sources were divided into three areas:

(1) references to maternal employment which totalled 41;

(2) references to child development literature pertaining particularly to separation from the mother, 26; and

(3) references to day care per se, 48.

No conclusions may be drawn from these statistics, however, without looking further into the nature of the literature itself. Typical of the references on maternal employment were articles concerned with the "Intelligent Hous ewife Syndrome" (Editor, Canadian 
Medical Association Journal, September 1964), "Captainesses of Industry" (Editor, il Economist, 1964); "Working Woman: Barriers in Employment" (Harrison, 1964). These articles all imply that women are not using their skills to the fullest. The last one even lists among the "barriers to employment" the obvious factor of child care problems; yet despite this concern with the resource of womanpower, little professional attention is turned to this most obvious obstacle. Other articles, notably in the medical literature concerned themselves more directly with the effect of maternal employment on the family. Typical of this group are such articles as "Strengthening Family Life: Mothers at Work" (Stewart, 1959); "Working Women and Their Families" (Pertego, 1965); and "Legal Protection of Infant Child of Working Mother" (Larrea, 1944). Again the literature shows an awareness of a reality situation and a willingness to deal with descriptive material; however, there is still a "professional lag" between these writings and research studies which come to grips with the problem of "strengthening family life" through the constructive use of day care facilities. Among the separation/child development articles were topics such as "Salutary Effects of Maternal Separation" (Seiden, 1965); "Separation Anxiety" (Bowlby, 1960); "Dependence and Independence in the Children of Working Mothers" (Siegel, et al., 1959). These articles reflect accurately Lois Meek Stolz's statement "that one 
can say almost anything about the children of working mothers and find a research study to substantiate it." (Stolz, 1960)

The current emphasis on group care--such as nurseries or day care centers--for educative and enrichment purposes, is reflected in 15 of these articles which describe, plead for, urge the licensing of or condemn the lack of such facilities. An example of this kind of day care facility is described by Caldwell and Richmond in "Foster Day Care: Programmed Day Care for the Very. Young Child" (1964), a study of an educationally enriched program for 25 . economically deprived youngsters. A special group of articles is also devoted to the problems of a nother group of deprived youngsters--the migrant children--and their specific day care needs. Reports by the Social Security Administration and/or Children's Bureau dealing with day care are confined to a statistical analysis of the kinds of day care services needed and available, the numbers of children in need of such services, and the responsibilities of welfare agencies in meeting these needs. Spotlight on Day Care, a summary of the proceedings of the National Conference on Day Care Services, held in Washington, D. C., on May 13-15, 1965, does contain a specific recommendation for family day care and lists two criteria for such care; to wit, that the "family day care mother be sensitized to the cognitive needs of the infants under care" (italics added) and that her salary "meet at least 
the national hourly minimal wage standard" (Spotlight on Day Care, 1965, p. 166).

The special issue on day care published by Child Welfare in March, 1965 contains one reference to family day care--that of Milton Willner--who also puts his finger on the essence of the problem of the professionals' barriers a gainst a constructive approach to day care: a middle class bias against working mothers. Willner points out that the concept of the working mother goes against the American ideal of a "secure family of firmly married parents... living in a community of more or less permanent residence." This ideal persists despite being "totally unrelated to the facts" which show a majority of day care users to be highly mobile one-parent families (Willner, 1965, p. 131). That day care traditionally has been provided primarily for lower class families is also pointed out by Ruderman (1964) who states that a class-and-caste system has developed around day care facilities, thus rendering them inaccessible to those middle class families who might desire them and reinforcing the bias. More recently a journalist, Sid Ross, in Parade Magazine, phrased the situation more bluntly:

. . the United States still thinks a woman's place is in the home. If she wishes to work, its belief holds, it's up to her to make arrangements for her children (Ross, 1967, p. 20).

The medical profession has shared with social work a generalized, but ironically not a particularized bias against working 
mothers; a recent series of articles described hospital-operated day nurseries that were set up to induce nurse-mothers to return to work immediately following childbirth! (Davis, 1965, 1966)

The impetus of the War on Poverty with its:Head Start Program has served to lend some respectability to the type of day care devoted primarily to an educational enrichment program; however, with few exceptions, these are geared to a school day (or half day) and only incidentally to meet the needs of the working mother. Yet, at the 1965 National Conference on Day Care Services, W. O. Heinze, President of Latex Corporation and Treasurer, Child Welfare League of America, speaking for business and industry stated that the "one-third of American mothers who work do so because business and industry needs them." (Spotlight on Day Care, 1965, p. 75) The Department of Labor predicts an increase of 17 percent in the number of working women between 1964 and 1970 (Spotlight on Day Care, 1965, p. 66). Though the gap between need and fulfillment is still filled with words rather than action, writers such as Willner and Ruderman are lighting candles and in recent years the words are getting more forceful and louder. The.U.S. Children's Bureau and Child Welfare League of America are underwriting research projects on day care; articles such as "Day Care as a Service for All Who Need It" (Close, 1965) and "The Need for Day Care" (Beer, 1962) are appearing in the literature. Even a magazine such as the 
Ladies Home Journal, traditionally the minion of middle class housewives, joined the trend and published a series of seven articles (May-Nov. 1966) on positive aspects of day care. This series contained one article devoted to a description of a licensed family day care home in a California community (Painter, Oct. 1966) and an evaluation of this plan (Kuh, Oct. 1966).

In the scope of the professional literature, only four researchers have dealt with family day care per se in any degree of depth; i.e., Perry, Ruderman, Collins and Emlen. Perry, in the work already cited, studied child care arrangements in Spokane, Washington. He made no attempt to evaluate these relationships from the standpoint of satisfaction to the mothers and day care givers; however, he concluded that the mothers must have had a high degree of confidence in their "sitters" because they left a minimum of instructions with them. He also observed that these arrangements were generally considered satisfactory if there were no complaints about the child care and the mothers had good employment records. Ruderman (1964), who surveyed seven selected United States communities regarding day care arrangements under the auspices of a Child Welfare League Association research grant, notes that mothers' expressed satisfaction with their day care arrangements may reflect a lack of perceived alternatives; however, she does not probe further into this phase of the problem. Nevertheless, the 
existence of perceived alternatives is crucial to an assessment of the genuineness of expressed satisfaction.

The present study developed independent measures of satis faction with, and dependence on, the day care arrangement which will be subsequently discussed. The conceptual model for this study is derived from a proposal for a field study designed by Emlen (1966) dealing with discontinuity of family day care arrangements. The field study in turn derived from the findings and experience of the Day Care Exchange Project which discovered a median duration of two weeks among a sample of terminated day care arrangements. The research proposal for the subsequent field study states in part that "the quality of care within a given arrangement frequently is eclipsed in impor tance by the problem of discontinuity in the day care arrangement." (Collins, 1966, p. 2) Discontinuity of the ar rangement was adapted as the dependent variable of the present study since researching bases for this phenomenon appeared to promise a valuable contribution to improved understanding of the arrangements themselves and the kinds of service social work might be able to offer.

The present study does not assume that discontinuity of a day care arrangement is necessarily harmful to children. Discontinuity of a poor arrangement or as a consequence of external factors-such as termination of maternal employment--may have benign 
consequences. Research literature on maternal employment (Nye and Hoffman, 1963) reveals that maternal employment per se (with its concomitant alternate child care arrangements) has not been associated with ill effects on children. The gross condition itself does not indicate what the crucial variables of child care may be that would bode ill for children. What has been as sumed, however, was that rapid and frequent turn-over in child care personnel, regardless of underlying reasons, is potentially harmful. It has also been assumed that working mothers would tend to prefer Jong-term, stable day care arrangements (if for no othex reasons than personal convenience) and would continue with the arrangement they found satisfactory as long as circumstances permitted. It has been further assumed that the working mother would be quite dependent on a day care arrangement--would, in fact, consider it a basic safeguard of her employment status. Thus satisfaction and dependence * were seen to contribute to continuity in an additive manner.

\section{Review of the Literature on Social Exchange}

Because the research literature on day care offered little beyond a wide range of unexplored areas for study, it was necessary

* The term "dependence" used in this study is not intended to carry psychological connotations, but refers simply to a preference for a given arrangement for lack of perceived alternatives that have value for the individual. This concept derives from Thibaut and Kelley (1959). 
to turn to the literature on social exchange and reciprocity to assist in formulating the hypothesis for the project. Since this study es sentially involves the study of dyads--mothers and sitters--the works of Blau (1964), Thibaut and Kelley (1959), Homans (1961) and Gouldner (1960) were most helpful.

Blau states that dyadic relationships are formed within a larger context and are thusly "affected by the alternative opportunities of each, with the result that competitive processes arise that include wider circles and that complement and modify the processes of exchange and attraction in this pair and in other pairs" (Blau, 1964, p. 32). Translated into the terms of this project, "the exchange and attraction" that exists in a given pair (mother and sitter) is rendered competitive in direct proportion to the numbers of "other pairs" that could be formulated; i.e., the "perceived alternatives" affect the formulation of the dyad.

Homans talks of the economic measures of the dyad--the costs and rewards of such a relationship. He says "social behavior is an exchange of goods, material goods but also non-material ones, such as the symbols of approval or prestige" (Homans, 1958, p. 606). Part of the assumption inherent in this study was the concept of costs and rewards in non-material terms. It was assumed that both mother and sitter received benefits from the arrangement that were not directly related to the monetary value; for example, an intrinsic value to 
the mother might be the companionship her child received from the - other children in the day care home while the sitter might consider the fact that she can stay home with her children more rewarding than the presumably greater income she could make on an "outside" job. Thibaut and Kelley discuss costs and rewards of (group) relationships as basic to continued interaction. They state that the magnitude of rewards to be gained by the two members will depend upon individual needs and values and the congruency of behaviors or behavioral products with these needs and values. Each person's reward may be derived directly from his own behavior and/or from the other's behavior (1959, p. 14). (Italics added)

Thus, the element of reciprocity may be an important factor in the continuity of a relationship.

This norm of reciprocity (Gouldner, 1960) was accepted as basic to this study. It was defined by Gouldner as an "internalized moral norm" which leads (men) not only to conform to the "expectations of others" but rather to reciprocate benefits. Further, it performs a stabilizing function in a relationship. Gouldner notes further that this norm is often not explicitly recognized until the existing relationship breaks down, and the underlying obligations are brought to light. A study of terminated relationships, therefore, appeared ideally suited for an analys is of reciprocity. 


\section{Theoretical Hypothesis of the Study}

These theories of reciprocal costs and rewards in dyadic relationships predicated the hypothesis for the study which is essentially a probe into a set of terminated relationships to tap valuations inherent in the formation, maintenance and termination of such arrangements.

For the purpose of setting up the hypothesis and describing the independent variables of satisfaction and dependence, it is useful to look at the model of $\mathrm{CL}$ and $\mathrm{CL}$ alt as described by Thibaut and Kelley where CL stands for comparison level and CL $\mathrm{L}_{\text {alt }}$ for comparison level for alternatives. The comparison level is "the standard against which the member evaluates the 'attractiveness.' of the relationship or how satisfactory it is." (Thibaut and Kelley, 1959, p. 21) The CL alt is defined as the "lowest level of outcomes a member will accept in the light of available alternative opportunities." (Thibaut and Kelley, 1959, p. 21) Thibaut and Kelley go on to state that as soon as outcomes drop below $\mathrm{CL}_{\text {alt }}$ the member will leave the relationship; i.e., discontinuity results. Both kinds of valuations described by Thibaut and Kelley are included in the measurement of both the satisfaction and dependence variables.

In this study, the theoretical hypothesis states that discontinuity is a function of the independent variables of satisfaction and 
dependence. These variables have to be probed in terms of their valuations for the worker roles and the (day care) user roles. The following schema (Figures 1 and 2) shows the theoretical structures used to develop the independent variables for both the mothers and the sitters.

Types of Evaluations

Roles

Satisfaction

Dependence

Working Mother Role:

Example: "I feel more important when I am working." Example: "My family couldn't get by if I didn't work."

Day Care User Role: Example: "Children learn a lot from $s$ taying in someone else's home dur ing the day."

Example: "If I want a sitter, I have to take what I can get."

Figure 1. The Value of the Arrangement to the Working Mother

Types of Evaluations

Roles

Occupationa1 Role:

Day Care Giver Role:
Satisfaction

Example: "If I
weren't doing baby-
sitting, I'd get
bored."
Example: "I get a
lot of satisfaction
out of seeing chil-
dren grow up."

Dependence Example: "I do baby sitting even though I don't especially need the money."

Example: "If I want to do baby sitting I have to take what I can get."

Figure 2. The Value of the Arrangement to the Sitter 
Thus, some degree either of satisfaction with or dependence on the arrangement was assumed to be a necessary and a sufficient condition for continuity of the arrangement. The four possible combinations of valuations and their expected relationship to continuity of the arrangement are shown in Figure 3.

Dependence

Satisfaction

\begin{tabular}{|c|c|c|}
\hline & \multicolumn{2}{|c|}{ Dependence } \\
\hline & High & Low \\
\hline High & Continuity & Continuity \\
\hline Low & Continuity & Discontinuity \\
\hline
\end{tabular}

Figure 3. Expected Relationship Between Continuity of the Arrangement and Satisfaction and Dependence

High Satisfaction plus High Dependence $=$ Continuity High Satisfaction plus Low Dependence = Continuity Low Satisfaction plus High Dependence = Continuity Low Satisfaction plus Low Dependence $=$ Discontinuity

It has been as sumed that satisfaction and dependence combine in an additive fashion and that the value of the arrangement may be comprised of many varied elements of satisfaction with and dependence on the arrangement. In order to test this hypothesis, two kinds of scales have been developed--one for role satisfaction and one for role dependence. These scales are an adaptation of Thibaut and 
Kelley's CL and CL alt $^{\circ}$ They were designed to provide (1) a measure of satisfaction with a day care arrangement in and of itself and (2) the need for such an arrangement in relation to alternative possibilities. The aim of measuring these two kinds of evaluative attitudes separately was to determine whether the respondents' perceptions of satisfaction or dissatisfaction with arrangements are conditioned by the presence or absence of preferred alternatives. While the satisfaction and dependence scales were generalized instruments, applying their conditions to any arrangements, a more particular scale was developed for the last terminated arrangement on which the research focused in detail. This scale (LAS = Last Arrangement Satisfaction) was designed to tap satisfactions arising from the particular interaction among mothers, sitters and family members in the last arrangement. The schedule which accompanied the scales was designed to probe further into the formation, maintenance, and termination dynamics of the last arrangement as well as to obtain general identifying information about the respondent. A further aspect of the hypothesis is introduced by the dimension of time and it was expected that a process of satisfaction or dissatisfaction might develop within the scope of the last arrangement. The interview schedule was also designed to explore this possibility. Although separate schedules were developed for the mothers and sitters, an attempt was made to keep the items 
sufficiently uniform to permit an analysis of reciprocity in the satisfaction items. The details of the scales, schedules, and methods of analys is will be discussed in Chapter III.

\section{Summary}

In summary, the hypothesis of this study states that discontinuity of a family day care arrangement is an additive function of satisfaction with and dependence on the arrangement. Satisfaction has been viewed as a separate kind of valuation, based on a respondent's standards of acceptability for an arrangement. Dependence on an arrangement has been determined by the scope of perceived alternatives for the arrangement. The hypothesis stated that any combination involving one high rating in either category would contribute to continuity; only a low score on both components was seen as a certain prediction of discontinuity. Moreover it was assumed that a system of intrinsic and extrinsic costs and rewards existed in these relationships. According to the theories of social exchange in dyadic relationships these costs and rewards had to be reciprocated to maintain the relationship. Thus the norm of reciprocity governed the analysis of the maintenance system. The decision to study the last terminated arrangement in depth was based on a desire to obtain as complete and accurate an overview as possible of an entire relationship--from formation through termination. 
This study is of social work concern from two standpoints. First, the subject of day care affects 12.3 million children and 6.1 million mothers; family day care in particular affects 984,000 children (under 14) of working mothers (Child Care Arrangements of the Nation's Working Mothers: A Preliminary Report, 1965). Secondly, the analysis of these relationships in the light of the theoretical framework of social exchange valuations incorporates some basic concerns of social work such as role concepts, selfperception, freedom of choice and cultural values. Thus, the project appeared to promise a unique and valuable contribution to social work research. 
CHAPTER III

METHODOLOGY

\section{Introduction}

This chapter describes the instruments used in the study, their content, and how they were developed to represent the theoretical concepts and aims of the study. The method of presenting the instruments to respondents is described and the resulting data are evaluated for their reliability, validity, and exploratory utility.

An empirical testing of a simple set of null hypotheses is described. These hypotheses were designed to correspond approximately to the theoretical working hypotheses, and their limitations are discussed.

Finally, the type of sample is described with attention to how it was obtained and some of its advantages and limitations for the purpose of this study.

In keeping with the exploratory aims of this initial research into the social interaction between mothers and sitters, an ex post facto study was designed in which the data collected would consist of the reports (the perceptions and evaluations) of mothers and sitters of their experiences with their last terminated day care arrangement. 
It was recognized that ultimately a more satisfactory way of studying factors associated with continuity and discontinuity of family day care arrangements would be to examine such arrangements in process over a long period of time. The present study was conceived in part as a pilot study for longitudinal examination of social interaction processes in the family day care system.

To predict continuity of the arrangement from its many sided value to mothers and sitters, one would want to measure valuations (the independent variables) at a point in time prior to termination of the arrangement which marks the end point of the dependent variable--duration of the arrangement. In the present study, however, the entire process of the arrangement was studied retrospectively after termination had occurred.

Collecting the data in this way raises the question about whether the valuations reported by mothers and sitters may not have been influenced to an unknown degree by the duration of the arrangement. While no causal inference can be made from the correlations between the independent and dependent variables in this study, the general working hypothesis was that satisfactions arising from the arrangement result in continuity of the arrangement, rather than the converse.

The validity of this retrospective study rests upon the success with which the respondents.' memories of their experiences and 
valuations could be stimulated and elicited verbally without excessive distortion. Respondents were asked to recall specific experiences with particular arrangemients. Scale items were in the form of . . "I felt the mother (sitter) took advantage of me, "involving a reference to self and to a párticular relationship.

Interview schedules (see Appendices $A$ and $B$ ) were designed to reconstruct the history of mothers' and sitters' experiences with the last arrangement. Following this discussion, scale items were presented in the interview situation. These items covered many varied sources of satisfaction with, and dependence on, the arrangement. The items were designed for use in the construction of summated-rating scales that could provide an ordinal level of measurement for the independent variables.

The interview schedule was designed so as to collapse the life his tory of one child care arrangement into a single interview. During the interview the respondent was helped to think back to the beginning of the arrangement and was led through a recapitulation of the sequence of her activity in the formation, maintenance, and termination of a single child care arrangement. She was asked on a global basis to indicate the changes in her feelings and evaluation of this particular child care arrangement. The interview schedule also contained questions designed to obtain specific background information regarding the users and givers of day care and to obtain 
data for the dependent variable--the number of weeks duration of the ar rangement.

\section{Method of Data Collection and Scale Construction}

The interview began with an identification of the particular day care arrangement that was to be discussed and that was to be the basic unit of analysis in this study. In this way factual material was obtained that served to define the arrangement, whom it involved, and when it occurred. In addition to obtaining the above information, this early identification served to help the respondent focus on one particular family day care arrangement. Structuring the focus of the interview in this way served to elicit the respondent's discrimination between her experience with a particular arrangement and her total experience as a user or giver of day care.

Once the focus of the interview was established, the respondent was asked to think back to before the arrangement began and to describe its formation. A question asked was: ". . . what did you look for?" The response to this item served to establish a base line of expectations of the arrangement for the individual involved, in comparis on with which she would evaluate her subsequent experience. The assumption was that the degree to which her expectations were met would be a factor in satisfaction (Thibaut and Kelley, 1959).

The next sequence in the interview centered on the respondent's 
evaluation of the arrangement at the point immediately after it had begun. In addition to a global reference to satisfaction, a schedule item was included to determine if this particular arrangement had those characteristics which the respondent had just indicated as being important to her in a child care arrangement. The item was: "You hardly ever find exactly what you are looking for. You have said you wanted - Did you have that in the arrangement with ?" Responses to this item proved to be important in the analysis of the data because they appeared to reveal a latent source of dissatisfaction even. for those women who reported satisfaction as a global judgment. This item "getting vs. not getting" was included in Guttman scales for both mothers and sitters, revealing a dimension of satisfaction in which women with a perceived freedom of choice reported getting what they were looking for in an arrangement.

Following the discussion of initial satisfaction, the interview then focused on changes in satisfaction that might have occurred during the arrangement's existence. This sequence included references to global satisfaction in terms of changes in satisfaction in such specific areas as convenience of the arrangement and the liking for the other party involved.

The next sequence in the interview centered on the termination of the child care arrangement and whether termination was due to 
circumstances or to dissatisfaction. A questioned asked to tap latent dissatisfaction was: "Would you take care of Mrs. X's children again?" (asked of the sitters) or "Would you have Mrs. X take care of your children again?" (asked of the mothers).

The last sequence in the life history of the day care arrangement dealt with the changes in the respondent's situation as a user or giver of day care immediately following the termination of the arrangement. In addition, her current status as a user or giver of day care was also explored.

At this point in the interview, the scale items for the three independent variables--satisfaction with the last arrangement (LAS), role satisfaction (RS), and role dependence (RD) were presented to the respondents. Each item was typed on a $3 \times 5$ card and presented to the respondent in a pre-established random order, with the exception that all items for the LAS scale were presented first. The LAS items were presented first because their content corresponded to the content of the interview schedule, which had just been completed; that is, the items for the LAS scale focused on a particular arrangement. Prior to the presentation of the LAS cards, it was explained to the respondents that the answers for this set of cards should be in terms of their feelings about the arrangement that had been discussed in the interview.

With the completion of the LAS cards, the RD and RS cards 
were introduced along with an explanation that the respondents' attention was now being directed to more general questions about working mothers and child care attitudes. The RD and RS cards were mixed and not presented as two separate units.

The items were read out loud to the respondent, one at a time, and the interviewer handed the card to the respondent who was instructed to place it in one of five sections of a partitioned tray designed to represent a Likert-type scale.* The sections were labeled "strongly agree, " "agree," "disagree," and "strongly dis agree." The middle section or "uncertain" response category was left unlabeled and was not used except when the respondent was completely unable to make a choice.

Reading the cards to the respondent enabled the interviewer to clarify meaning, particularly for those items which were difficult in content and construction. When the respondent appeared to be confused on an item, this type of presentation created an opportunity to correct such confusion as the interviewer and respondent went through the cards together. Occasionally a respondent, as she considered a particular item, would ask for direction, not in deciding what her thought or response to the card was, but to elicit confirmation that her expressed thought or response to the item was a

* The idea for using such a tray came from Levinson and Gallagher (1964). 
decision to "agree" or "disagree." For example, item 12 (sitter) reads, "The children hated to leave me." A sitter might say, "No, they didn't hate to leave me, so do I agree or disagree?"

This procedure appeared to reduce the amount of error with which the respondents indicated their attitudes and selected the section of the tray that the responses belong in. Our confidence that this procedure resulted in more reliable and valid data than might have been obtained through the unaided presentation of the scale items in a written questionnaire finds some support in McGinnis. McGinnis pointed out, however, that scaled interview dată and scaled questionnaire data can "result in radically different placement of the same subjects with respect to the same variable." (McGinnis, 1953, p. 521)

Only one exception to this verbal presentation of cards was made. This was a situation of a sitter who had three terminated arrangements and data for all three arrangements was collected in a single interview session. For the first arrangement the cards were presented verbally. Midway through the presentation of the cards for the second arrangement the sitter, who was being dis $-*$ tracted by a crying, hungry child, sugges ted that she read the cards herself, and that the interviewer help with the baby.

After the presentation of all the items, background information was obtained from the respondent. This included the collection of 
data on such items as previous child care arrangements, work history, educational level and income.

All interviews were held in the respondents' homes. A letter was sent to each respondent (see Appendix E) describing the nature of the study and asking for her participation. The letter also indicated how the respondent's name had been obtained; that is, through the Day Care Exchange Project, through the Multnomah County Public Welfare Commission, or in the case of a sitter for a welfare mother the name of the mother who had given us the sitter's name.

Whenever possible the respondent was contacted by telephone and an appointment made for the interview. In those cases in which the respondent did not have a telephone, a suggested appointment time was indicated in the letter.

Three Likert-type scales were constructed for both the mothers and the sitters. These scales were designed to measure the independent variables--satisfaction with the last arrangement (the LAS scale); satisfaction in the role of a working mother and user of day care, or in the role of a giver of day care (the RS scale); and dependence on the role of working mother and user of day care, or on the role of giver of day care, based upon restrictions of perceived alternatives (the RD scale).

The use of these three variables with scales to represent each was determined by the theoretical assumption that there are two 
main types of evaluations made by people--satisfaction with and dependence on something. Properly mea'sured, it should be possible to distinguish between those who are dissatisfied with a child care arrangement perceived as the only alternative and those who fall into the other three categories: high satisfaction-high dependence, low satisfaction-low dependence, or high satisfaction-low dependence. We assumed that degree of satisfaction with and degree of dependence on, the arrangements were different dimensions measurable as such. If this assumption was correct, we would expect that the correlations between the various independent variables would be low.

The items were presented to the respondent verbally within the context of the interview. The respondent was asked to indicate on a five point rating scale the degree of her agreement or ditsagreement with each item. From her responses a summated rating could be made of her satisfaction with the last arrangement, her role satisfaction and her role dependence. The relationship between the various summated ratings and the duration of the child care arrangement would be explored. It was anticipated that the duration of the arrangement would have a positive correlation to any of these three components and to the additive components of role satisfaction and role dependence.

It should be noted that in this study satisfaction with the child 
care arrangement was not taken as a global judgment but measured, as a composite of many diverse sources of satisfaction. The scales were designed to do this. This was an approach that appeared relatively satisfactory since the one schedule question that attempted to obtain a global judgment of satisfaction elicited an almost universal high response. The following examples of items used illustrate the elements of satisfaction and dependence that contributed additively to the measurement of these variables:

$\begin{array}{ll}\begin{array}{l}\text { Mothers' LAS } \\ \text { Mothers'RS }\end{array} & \begin{array}{l}\text { I like the daily routine of going to work. } \\ \text { Mothers'RD }\end{array} \\ \begin{array}{l}\text { If necessary, I could quit work and stay at } \\ \text { home. }\end{array} \\ \text { Sitters' LAS } & \text { I felt the mother took advantage of me. } \\ \text { Sitters' RS } & \begin{array}{l}\text { Child care is one of the most impor tant } \\ \text { jobs a woman can have. }\end{array} \\ \text { Sitters'RD } & \begin{array}{l}\text { If I want to do baby sitting, I have to take } \\ \text { what I can get. }\end{array}\end{array}$

The final scales were arrived at through item-analysis procedures designed to yield scales that consisted of the best discriminating items, that is those items that had the best ability to discriminate between the high ranking respondents and the low ranking respondents (Edwards, 1957).

The discriminatory power of each item in a scale was determined by first rank ordering all respondents on the basis of their summated ratings, and then calculating for each item the difference 
between the mean scores for those respondents who were in the highest and lowest quartiles. In using this method, the standard is not to include items with a discriminatory power of less than 1.00, where strongly agree is 4 and strongly disagree is 0 (Goode and Hatt, 1952).

Item analysis results for the six scales were as follows:

$\begin{array}{lcc}\text { Scale } & \begin{array}{c}\text { Range of } \\ \text { D.P.'s } \\ \text { above } 1.00\end{array} & \begin{array}{c}\text { Number of Items } \\ \text { with D.P of } \\ 1.00 \text { or more }\end{array} \\ \text { Mothers' LAS } & 1.32-3.50 & 24 \\ \text { Mothers' RD } & 1.00-2.14 & 13 \\ \text { Mothers' RS } & 1.28-2.86 & 24 \\ \text { Sitters' LAS } & 1.32-2.50 & 24 \\ \text { Sitters'RD } & 1.00-2.33 & 12 \\ \text { Sitters' RS } & 1.00-1.33 & 11\end{array}$

It will be noted that a sufficient number of items with a discriminatory power of at least 1.00 were lacking for three of the scales. For each of these three scales additional items were included which, although having a discriminatory power of less than 1.00, were similar in content to the high discriminatory items.

The number of items in each scale as thus constructed were: mothers' LAS--24, mothers' RD--24, mothers' RS--24, sitters' LAS--24, sitters' RD--20, and sitters' RS-19. 
As was stated earlier three variables were used in measuring the respondents' assessment of the value of their child care arrangements, on the assumption that different people would use different criteria in evaluating such an arrangement. The three scales were thus designed to tap different sources of satisfaction with the arrangement, sources of satisfaction which would operate quite independently of each other. Thus it would be expected that correlations between the different variables would not be statistically significant, or would be of a very low order of correlation. Such an assumption, with the exception of the correlation between the sitters' role satisfaction and her satisfaction with the last arrangement, was supported by low rank order correlations between the different variables.

TABLE I

RELATIONSHIPS BETWEEN THE SCALES FOR THE INDEPENDENT VARIABLES

\begin{tabular}{lcc}
\hline Variables & $\begin{array}{c}\text { Sitters, } \mathrm{N}=23 \\
\text { Rho }\end{array}$ & $\begin{array}{c}\text { Mothers, } \mathrm{N}=27 \\
\text { Rho }\end{array}$ \\
\hline RS, LAS & $.48 *$ & .05 \\
RD, LAS & -.13 & -.26 \\
RD, RS & .16 & -.23 \\
RD + RS, LAS & .14 & -.10 \\
\hline $\mathrm{p}<.05$ & &
\end{tabular}




\section{Evaluation of the Scales}

The scales were evaluated on the basis of their internal consistency and on their ability to discriminate (Edwards, 1957).

The internal consistency of each scale was determined by a split-half (odd-even) coefficient of reliability, with the results shown in Table II. The Spearman-Brown formula was used to give the corrected reliabilities for the length of the test.

TABLE II

RELIABILITY OF THE SCALES

\begin{tabular}{lccc}
\hline Scale & $\mathrm{r}$ & $\mathrm{r}$ & $\mathrm{N}$ \\
& .95 & .97 & 24 \\
LAS mothers' & (corrected for length) & (items) \\
LAS sitters' & .90 & .95 & 24 \\
RS mothers' & .71 & .83 & 24 \\
RS sitters' & .56 & .72 & 19 \\
RD mothers' & .56 & .73 & 24 \\
RD sitters' & .52 & .69 & 20 \\
\hline
\end{tabular}

It may be seen that the LAS scales for both the mothers and sitters were highly reliable, while the reliability coefficients for three of the scales were somewhat lower than are customary for Likert-type scales (Edwards, 1957). 
A split-half (odd-even) test is the accepted way of evaluating the reliability of summated rating scales of Likert-type items, and no test-retest was attempted. However test-retest data were available on three cases where the same person was interviewed about more than one arrangement. These cases showed close consistency on the role dependence scales and on the role satisfaction scales. As might be expected, there were differences in the satisfaction on the last arrangement scales. Although not at all definitive, these differences contributed to our confidence that the LAS scales did measure what they purported to do, namely satisfaction with the las t child care arrangement.

The ability of each scale to discriminate was determined in part by the dispersion of the summated ratings obtained from each scale. (See Table III.)

TABLE III DIS TRIBUTION OF SCALE SCORES

\begin{tabular}{lrcccc}
\hline \multicolumn{1}{c}{ Scale } & Range & Median & Mean & S.D. & N \\
\hline LAS mother & $13-94=81$ & 69 & 61.5 & 23.16 & 28 \\
LAS sitter & $28-93=65$ & 69 & 68.0 & 17.7 & 27 \\
RS mother & $3-72=69$ & 43 & 41.0 & 17.9 & 27 \\
RS sitter & $32-62=30$ & 49 & 49.0 & 7.74 & 23 \\
RD mother & $45-82=37$ & 66 & 63.8 & 9.72 & 27 \\
RD sitter & $21-54=33$ & 36 & 35.7 & 8.55 & 23 \\
\hline
\end{tabular}


On the basis of the internal consistency and the ability of the scale to discriminate, it can be seen that the LAS scales for both mothers and sitters and the mothers'RS scale were superior to the other scales. Without a pretest distribution of scores to go on, it was not possible to know what level of difficulty of the items would result in an optimum distribution of scores; therefore an insufficient number of discriminating items remained for three of the scales constructed. Other reasons for confidence in the LAS scale were:

(1) The high split-half reliability for both the mothers and sitters which was .97 for the mothers and .95 for the sitters.

(2) The zero correlation between the LAS scale and the RS scale for the mothers $(\mathrm{Rho}=.05)$. There was a significant, but moderately low correlation between the LAS scales and the RS scales for the sitters (Rho $=.48)$, A possible reason for this may be that sitters are apt to have more than one arrangement at a time and a sitter's satisfaction with a particular arrangement may be influenced by or associated with her satisfaction with other arrangements that existed at the same time.

An indication of the external consistency of the scales was obtained by comparing responses to the scale items 49,54 and 75 with 
the responses to a similar item in the interview schedule, and it was noted by inspection that the responses in both instruments were consis tent.

In addition, the LAS scores were compared with the responses to the interview questions regarding changes in global satisfaction and the responses to the question regarding whether or not dissatisfaction was a reason for termination. No gross inconsistency was found.

An indication of the reliability of the dependent variable was obtained by comparing the data regarding duration of the arrangement for those cases in which both the mother and sitter in the same arrangement were interviewed, $N=20$. Although there were differences between the mothers' and sitters' responses, these differences were not sufficient to affect seriously the rank ordering of respondents on the dependent variable. For the twenty arrangements in which paired data were available, the rank order correlation of mothers' and sitters' responses was $\mathrm{Rho}=.90$.

One of the defects in the collection of the data was the time lapse between the termination of the day care arrangement and the date of the research interview. For the mothers this time lapse ranged from one to nineteen weeks, with a median of seven weeks. For the sitters the range was two to twenty-four weeks, with a median of eight weeks. 
The data for some items on the schedule was affected by this time lapse. The study had hoped to ascertain how much a sitter's or working mother's income contributed to total family income. The time lapse, as well as the wording of these items on the interview schedules, made it difficult to evaluate this data adequately.

The time lapse also affected responses to the interview schedule items that had to do with the respondent's behavior as a day care giver or user following termination of the discussed ar rangement.

The data for the dependent variable was also affected by the time lapse. Almost all mothers and sitters had difficulty recalling the starting and termination dates of the child care arrangement. In only two cases, both of them sitters, had the respondent kept a written record to which she could refer in answering this question.

\section{Data Analysis}

The theoretical hypothesis for this study was that the duration of the day care arrangement would have a positive correlation with the value of the arrangement for the individual. Four null hypotheses for each of the two samples--the mothers and the sitters--were used in tes ting this theoretical assumption.

The results obtained by Spearman Rank Order correlations were not statistically significantly different from zero and did not 
result in the rejection of the null hypothesis. (See Table IV.)

TABLE IV

DURATION OF THE ARRANGEMENT BY SCALE SCORES

Mothers

LAS, duration

RS, duration

$R D$, duration

$R D+R S$, duration
Rho

.22

$-.18$

$-.21$

$-.22$

$-.14$

$\mathrm{N}=27$

$-.04$

$N=23$

RS, duration

$-.02$

$\mathrm{N}=23$

$R D+R S$, duration

$-.08$

$N=23$

These results led to a further analysis of the independent variables by Guttman scale analysis, which is described in.Chapters IV, V and VI. In the case of the mothers the Guttman scale in Chapter IV was found to be correlated with the duration of the arrangement, significant at the one percent level.

\section{Method of Collecting the Sample}

The sample for this study was collected from two agencies, the Multnomah County Public Welfare Commission and the Day Care Exchange Project of nor thwest Portland. 
At a meeting with representatives of the Multnomah County Public Welfare Commission it was determined that the most feasible way of collecting a sequential sample of terminated family day care arrangements would be through the use of grant authorization documents which are processed by the agency whenever a welfare recipient has a change in financial need. A welfare recipient who is paying for some type of child care has the cost of this item included in her grant. When a recipient reports a change in the cost of this item, or reports that the item is no longer needed, the welfare caseworker authorizes a grant change by the use of this document. Such authorizations usually are done within the month that the change occurs.

The collection of all authorization documents that showed either a change in or a deletion of the cost of child care provided a sampling frame of terminated day care arrangements. Such a procedure would result in an unknown sample loss due to the possibility of unreported terminations. In addition it was assumed that some mothers would change sitters without requiring a change in the budget item for the cost of child care.

Screening was necessary (a) to determine if the change in cost represented a termination of an arrangement and (b) to determine if the arrangement had actually been for day care of the type to be studied--family day care in the home of a non-relative. This screening was done by two members of the research group contacting 
the caseworker who had authorized the grant change. It was found that in most cases the caseworker was able to supply information from which a decision could be made as to whether or not the case should be included in the sample (that is, was it a terminated family day care arrangement). For those cases in which the caseworker was unable to supply this information, the researchers did the screening themselves. This method of screening was successful. In the subsequent interviews of the mothers obtained in this manner, all but one met the criteria for a terminated family day care arrangement.

Authorization documents were collected during the month of November, 1966. During this period of time there were 87 authorizations for either a deletion of or change in the cost of child care. Of these 87 authorizations, 14 were found to be the result of a termination of a family day care arrangement.

In the process of screening the 87 authorizations with the welfare casework staff, other terminated day care arrangements were found which had not appeared as grant authorization changes in the month of November. Some of these were arrangements which had been terminated prior to November and others were terminations which the caseworker knew about but for which he had not authorized a grant change. Since a probability sample was not desired for this study and since these arrangements met the criteria specified, it 
was decided to include them in the sample. This method resulted in obtaining ten additional terminated family day care arrangements. When added to the terminated arrangements obtained from the grant authorization documents, our potential sample from the welfare department was 24 terminated day care arrangements.

The sample loss from these 24 arrangements was two. Both of these mothers declined to be interviewed as they "didn't have time." One of them was working a split shift, necessitating her being away from home approximately twelve to fourteen hours a day.

During the interviews with the welfare mothers, the respondents were asked to give the name of the sitter who had provided day care in the terminated arrangement. All the mothers did this, and also gave their permission to interview the sitter.

From the 22 welfare mothers interviewed, we obtained the names of 23 baby sitters who had provided day care for their children. The extra baby sitter was the result of one mother's having had an additional terminated arrangement between the terminated arrangement for which she was referred to the sample, and the date of the interview.

Sample loss for this group of baby sitters was eight. One baby sitter refused to be interviewed. The mother in this arrangement indicated that termination had been most unpleasant, involving a disagreement about payment which had necessitated the intervention 
of the welfare department. Seven of the baby sitters could not be located. It appeared that some of them had moved, and others were just not available for appointments.

An additional terminated day care arrangement was obtained from a woman who was interviewed twice--first as a sitter for a welfare mother, and then as a working mother and user of family day care.

In summary, the welfare sample consisted of 23 mothers and 16 sitters. Paired data, representing terminated arrangements in which both the mother and sitter were interviewed, was collected for 15 arrangements.

As described in Chapter I, the Day Care Exchange, through the net work of the Day Care Neighbors, has developed a system through which private family day care arrangements can be located. This agency arranged for the Day Care Neighbors to report terminated arrangements that occurred during the months of September and October of 1966.

The social worker serving the Day Care Exchange Project has regular monthly contacts with Day Care Neighbors. As plans were made for the research project, the Day Care Neighbors were advised of the need to locate terminated arrangements, and were requested to report to the Exchange social worker all terminated day care arrangements that came to their attention. The Exchange then 
referred the names of mothers and sitters for inclusion in the sample.

During the months of September and October, 1966 the Day Care Neighbors reported terminated arrangements. These arrangements required only minimal screening. Of the ten arrangements referred two were not accepted, one because it was a child care arrangement necessitated by the mother's illness, rather than by her employment or participation in vocational training, and the other because it was an arrangement that an employed father had for his motherless children. This sampling frame provided eight child care arrangements. However, this number of arrangements was expanded in the process of interviewing the mothers and sitters, as it was found that some of the respondents had intervening terminated arrangements, which had occurred between the date of termination of the referred arrangement and the date of the interview. Such terminations had not been reported to the Exchange office. In this manner five additional terminated arrangements were obtained.

This resulted in a potential sample of 13 terminated day care arrangements. These arrangements involved eight baby sitters, and 12 mothers.

The sample loss for the 12 mothers was eight. This high sample loss was primarily due to moves made by the mothers. 
Seven mothers were no longer living at the address listed by the Day Care Exchange, and attempts to locate them through followup letters, contacts with relatives, neighbors, and former baby sitters were successful in only one case. The eighth mother could not be interviewed as she was vacationing in Hawaii.

Sample loss for the eight sitters was one. This sitter had moved, and her current address was not available.

The sample from the Day Care Exchange Project therefore included four mothers, who represented five terminated arrangements, and seven baby sitters, who represented 11 terminated arrangements. Paired data, representing terminated arrangements in which both the mother and sitter were interviewed, was collected for five arrangements.

The final samples were arrived at by combining the respondents from the welfare department and from the Day Care Exchange. Twenty-seven mothers were interviewed regarding 28 terminated family day care arrangements, and 23 sitters were interviewed regarding $27 \mathrm{such}$ arrangements. As indicated earlier, there is a difference in the number of mothers to arrangements, and a difference in the number of sitters to arrangements. This is because one mother had two terminated arrangements and two sitters had two terminated arrangements, and one sitter three terminated arrangements. 
From the above samples of sitters and mothers, a sample of 20 paired terminated arrangements was constructed; that is a sample in which data was obtained from both the mother and sitter involved in the same arrangement.

Thirty-five terminated arrangements were actually included in the study. In addition to the 20 paired arrangements, there were eight arrangements in which only the mother was interviewed, and seven arrangements in which only the sitter was interviewed.

In discussing methodology and findings, it will be noted that under certain conditions the sample used is the number of arrangements, and at other times the sample used is the number of individuals, i.e., mothers or sitters.

These mothers and sitters represent a non-probability sample from the universe of terminated family day care arrangements. Since this is a non-probability sample, the study makes no attempt to estimate parameters of the general population of working mothers and their baby sitters. The instruments that were developed for use in this study and the findings of this study may be seen as having exploratory value that may stimulate further research into the social interaction processes of the private family day care system. 
CHAPTER IV

\section{THE MOTHERS}

\section{Introduction}

In this chapter the sample of working mothers is described and the findings presented and discussed.

A generally favorable response by the mothers to the research interview facilitated the gathering of data. When the mothers were initially contacted they responded to the request for help with varying degrees of enthusiasm. Some had been alarmed by the letter but were reassured by the personal contact and became intrigued after an explanation of the purpose of the study. They expressed interest in participating and the majority went out of their way to cooperate in arranging time for an.interview in spite of personal inconvenience.

At the conclusion of the interview the mothers were asked for any comments they cared to make. The responses revealed a general and personal concern about the whole question of child care. They made comments such as: "I'd sure like to know what you find out" and "I hope this helps you do something to improve the situation, "or "I never thought much about some of these things before, but it sure is a problem." 
Many behaved in the interview situation as if they were relieved to be able to talk about the problem, and some implied that they felt pressured to work and were resentful of this. These thoughts were revealed in random comments and conversation incidental to the interview.

\section{Characteristics of the Sample}

Of the 27 mothers interviewed in the 28 arrangements, 23 were referred by the welfare department of whom seven were receiving supplemental assistance at the time of the interview; the remainder were carried as service cases. The other four mothers were referred by the Day Care Exchange Project. Because of the small number of referrals from the Day Care Exchange, no comparison of the two samples was attempted; rather, a11 27 mothers were considered as the "working mother sample."

Vital statistics concerning the mothers and their families are presented in Tables V and VI.

The interviewing schedule was divided into three parts: (1) making the arrangement; (2) maintaining the arrangement: (3) ter minating the arrangement. All answers were geared to the mother's

* One mother was interviewed twice, in regard to two separate arrangements; hence while there were only 27 mothers in the study, data was obtained from mothers on 28 arrangements. 
TABLE V

PERSONAL CHARACTERISTICS OF MOTHERS

\begin{tabular}{|c|c|c|c|c|c|c|}
\hline \multicolumn{2}{|l|}{ Ages * } & \multicolumn{3}{|c|}{ Educational Level } & \multicolumn{2}{|c|}{ Marita1 Status } \\
\hline Under 20 & 1 & & Some H. S. & 9 & Married & 6 \\
\hline $20-30$ & 20 & & H. S. grad. & 10 & Div. or Sep. & 19 \\
\hline $30-40$ & 6 & & GED \& Voc. & 5 & Unwed & 2 \\
\hline & - & & Some college & 3 & & \\
\hline Totals & 27 & & & 27 & & 27 \\
\hline \multicolumn{3}{|c|}{ Occupation } & \multicolumn{2}{|c|}{ Length of Employment } & \multicolumn{2}{|c|}{ Race } \\
\hline Clerical & & 7 & 1 yr. or less & 11 & White & 20 \\
\hline Service work & & 14 & $1-3$ yrs. & 10 & Negro & 7 \\
\hline Skilled trade & & 1 & 10 or more & 5 & & \\
\hline Student & & 5 & Unknown & 1 & & \\
\hline Totals & & 27 & & 27 & & 27 \\
\hline
\end{tabular}

* Thirteen of the age figures are estimated.

TABLE VI.

INCOME LEVELS *

Under \$2, 999

17

14

$\$ 3,000$ to $\$ 4,999$

$8 \quad 7$

$\$ 5,000$ to $\$ 10,000$

$0 \quad 3$

Unknown

$\frac{2}{27} \quad \frac{3}{27}$

* Four of these families were from the "non-welfare samples;" they account for the three in the "high-income" group. Only seven of the 23 welfare mothers were receiving supplemental $A D C$ at the time of the interviews. 
last arrangement which subsequently was analyzed in terms of meeting the mother's expressed criteria, providing satisfaction, and some measure of stability. Because Perry's study (1961) indicated a large number of "informal" arrangements were based on friendship or at least casual acquaintance, an attempt was made to determine how the mother and sitter found one another. Thirteen of the 27 mothers indicated that they and the sitters were "friends" prior to the arrangement; only six were strangers. Of the 28 arrangements, 18 were initiated by the mother; ten by the sitter. None of the mothers interviewed had used newspaper ads or employment agencies, though four were brought together by the Day Care Exchange.

\section{Characteristics of the Last Arrangement}

Fifty-nine children were included in the last arrangements of 27 mothers. Over half (32) of these children were in the $1-3$ age bracket. Twenty-four were of school age $(6-13)$; three were kindergartners (age 5); and one was an infant. The cost of care varied from $\$ 1.00$ per day for two children for seven hours to $\$ 4.00$ per day for two children for seven hours. The feebears more relation to the number of hours per day that care was given than to the number of children involved, but no set fee was apparent. Four mothers provided food or paid for extras. 
The distance to the sitter's home is shown in the following cumulative frequency table:

\section{Distance}

Next door or across street

Within one block away

Within six blocks

Within one mile

Within ten miles
Cumulative Frequency

5

14

21

26

28

The mothers' expressed requirements for a day care arrangement were: *

Good care 18

Responsibility and dependability 10

Sitter must like children 12

Convenience 5

Cleanliness (of day care home) 5

Sitter must be older than teen age 4

Price must be right 3

Similar ideas about discipline 3

Did the mothers get what they were looking for? The answers to this question scored as follows:

Yes (got everything that she was looking for) 9

No (got nothing that she was looking for) 2

Partially (got some of what she was looking for) 16

Total 27

* The mothers were encouraged to list as many criteria as seemed significant to them. 
Thus, only one third of the mothers met all their requirements in their last arrangement. This factor made a significant impact on the course of the arrangement--maintenance and termination--as discussed in the subsequent analysis.

Maintenance Behavior: Whose Responsibility?

The question asked of the mothers was, "We would like to know how you keep a babysitting arrangement from falling apart. What does it take to keep a babysitting arrangement going ?" The responses were classified independently by three judges according to whether the mother thought it was up to her or up to the sitter to do the accommodating in the relationship. There was complete agreement on two-thirds of the responses. The rest were reviewed and consensus was reached on them jointly, in order to arrive at trustworthy ratings. The maintenance behavior orientation of the mothers is presented in Table VII.

Although maintenance was seen by the majority of the mothers as their responsibility, they did not appear to carry this out in actual practice. Often neither party to the arrangement was particularly aware of any deliberate activity to promote harmony in this area. Once the arrangement had been made, both expected it to continue without any specific effort on their part. A considerable amount of attention has been given to the question of training and certifying 


\section{ORIENTA TION OF MOTHERS TOWARD MAINTENANCE OF RELA TIONSHIP WITH SITTER}

Mother attributes one-sided power to sitter and takes the burden of responsibility upon herself for trying to maintain the relationship. $N=19$
Mother sees power as balanced and either assigns the responsibility for maintaining the relationship to the sitter or sees it as shared mutually. $\mathrm{N}=8$.
Verbatim excerpts:

Agree on discipline; don't jump on sitter.

Pay baby sitter on time; suit your needs around sitter's; handle sitters with kid gloves.

Have your children mind and not sass; good pay.

Keep a tape over my mouth. I find it hard, because they do not take care of them the way I would; it takes all my nerve just to keep my mouth shut; I have to put up with what I can get 'cause that's the only way to keep one, and to get a good one you have to put out a good bit of money.

It's the mother's responsibility; don't be demanding or ask too much of the sitter; make the sitter's job a happy one; be considerate of sitter. Mother must protect her child and interfere only if baby sitter is irresponsible or doesn't give good care.
Verbatim excerpts:

Mother and sitter have to have same viewpoint; sitter needs to be able to "talk to kids" like mothers.

Mutual agreement between sitter and mother regarding expectations.

Being good friends; knowing each other's ways.

We didn't take advantage of each other; good friends; be considerate of each other.

Sitter and mother agree on same things to do.

Cooperation between baby sitter and parent; sitter should learn likes, dislikes, and habits of the child so they could be a second mother; mother can ignore "tattle-taleing" of child.

It depends on circums tances, such as location and length of knowing each other, and on compatability of needs of mothers and baby sitters. She wanted something to do and needed money and I wanted someone close and good. 
baby sitters, but possibly mothers need to be educated in how to initiate and use child care satisfactorily.

When the mothers first made the arrangement, only three of them were dissatisfied with it, but when asked if anything changed in their feelings of satisfaction during the life of the arrangement, 14 mothers, including two of the originally dissatisfied, indicated that they had become less satisfied as time went on. Nine mothers decided to terminate because of dissatisfaction. All nine of these were among those who became less satisfied during the course of the arrangement.

\section{Termination of the Last Arrangement}

These terminated arrangements discussed by the mothers ranged in duration from one day to three and one half years, with the median length being seven weeks. Only seven of the arrangements lasted for six months or longer.

Since the focus of the study was an analysis of terminated arrangements, the mothers were asked to $s$ tate their reasons for termination and their perception of the responsibility for termination; i.e., mother, sitter or other (such as husband or family member). The replies to "Why did this arrangement terminate?" were classified as follows: 
Changes in sitter's situation

13

Dissatisfaction with care

Change in mother's need

Thus, almost half of the arrangements were terminated by the sitter. This factor was also borne out in the mothers' replies to "Who terminated the arrangement?"

\begin{tabular}{|c|c|}
\hline Sitter's decision & \\
\hline Mother's decision & \\
\hline Mutual agreement & \\
\hline Sitter's husband & \\
\hline & Total \\
\hline
\end{tabular}

The high ratio of sitter-determined terminations is especially significant in view of the statements made by 15 (over one half) of the mothers indicating that they were at least partially dissatisfied with the arrangement; nevertheless they did not take the initiative in seeking its termination. Their complaints ranged from one mother's all-inclusive "everything" to such specifics as "a cold house;" most of the complaints, however, centered around poor child care, poor facilities and harsh discipline. In spite of their complaints, five of the 15 dissatisfied mothers found partial

* Not necessarily same 13 who indicated changes in sitter's situation. 
satisfaction in the arrangement; only seven said the would not use the same sitter again.

\section{$\underline{\text { Sources of Role Satisfaction and Role Dependence }}$}

Of the 34 Likert-type scale items relating to satisfaction with working mother and day care user role, 24 were selected on the basis of their ability to discriminate between mothers who scored high and low on the items. This is described in Chapter III. The twenty-four best scale iterns on Mothers' Role Satisfaction are shown in Table VIII.

TABLE VIII

SUMMA TED-RA TING SCALE OF MOTHERS' ROLE SATISFACTION (mothers' RS)

\begin{tabular}{|c|c|c|c|c|}
\hline \multirow{2}{*}{ Item } & & \multicolumn{2}{|c|}{ Frequency } & \multirow{2}{*}{$\begin{array}{l}\text { Mean } \\
\text { Score }\end{array}$} \\
\hline & & Low & High & \\
\hline 73. + & $\begin{array}{l}\text { I feel more important when I am } \\
\text { working. }\end{array}$ & 9 & 18 & 2.44 \\
\hline $54 .+$ & $\begin{array}{l}\text { I would rather leave my child with a } \\
\text { sitter than with a relative or mem- } \\
\text { ber of my own family. }\end{array}$ & 11 & 16 & 2.22 \\
\hline 48. & $\begin{array}{l}\text { I get criticized for leaving my child } \\
\text { with a babysitter. }\end{array}$ & 10 & 17 & 2.22 \\
\hline 88. + & Working keeps me from feeling bored. & 11 & 16 & 2.22 \\
\hline $69 .^{\prime}-$ & $\begin{array}{l}\text { My children are harder to handle } \\
\text { since they have been going to a baby- } \\
\text { sitter's. }\end{array}$ & 10 & 17 & 2.18 \\
\hline 41. + & $\begin{array}{l}\text { I like the daily routine of going to } \\
\text { work. }\end{array}$ & 10 & 17 & 2.18 \\
\hline
\end{tabular}


TABLE VIII (continued)

\begin{tabular}{|c|c|c|c|c|}
\hline \multirow{2}{*}{ Item } & & \multicolumn{2}{|c|}{ Frequency } & \multirow{2}{*}{$\begin{array}{l}\text { Mean } \\
\text { Score }\end{array}$} \\
\hline & & Low & $\mathrm{High}$ & \\
\hline 49. & $\begin{array}{l}\text { - I'd rather have my child at a day } \\
\text { care center than at the home of a } \\
\text { sitter. }\end{array}$ & 12 & 15 & 2.18 \\
\hline $56 .+$ & + I am happier when I am working. & 11 & 16 & 2.15 \\
\hline 47. & $\begin{array}{l}\text { - I have been criticized more than } \\
\text { once for being a working mother. }\end{array}$ & 13 & 14 & 2.03 \\
\hline 65. & $\begin{array}{l}\text { - I worry about leaving my child with } \\
\text { a sitter. }\end{array}$ & 14 & 13 & 2.00 \\
\hline $51 .+$ & $\begin{array}{l}+ \text { I am appreciated more at home } \\
\text { when I am working. }\end{array}$ & 15 & 12 & 1.85 \\
\hline 36. - & $\begin{array}{l}\text { - I really would prefer to stay home } \\
\text { myself. }\end{array}$ & 15 & 12 & 1.81 \\
\hline 76. + & $\begin{array}{l}+ \text { On the whole, I think I can be a better } \\
\text { mother if I work. }\end{array}$ & 17 & 10 & 1.66 \\
\hline 46. - & $\begin{array}{l}\text { - It bothers me that I can't have the } \\
\text { kind of child care arrangement I } \\
\text { would really like. }\end{array}$ & 16 & 11 & 1.63 \\
\hline 83. + & + I enjoy getting away from housework. & 17 & 10 & 1.63 \\
\hline 74. + & $\begin{array}{l}\text { + Having a job is better than being just } \\
\text { a hous ewife. }\end{array}$ & 18 & 9 & 1.59 \\
\hline 61. - & - I wish I didn't have to work. & 18 & 9 & 1.41 \\
\hline 97. & $\begin{array}{l}\text { - In general I'm not in favor of } \\
\text { mothers working. }\end{array}$ & 18 & 9 & 1.41 \\
\hline 84. - & $\begin{array}{l}\text { - Mothers shouldn't work unless they } \\
\text { absolutely have to. }\end{array}$ & 19 & 8 & 1.22 \\
\hline $79 .+$ & $\begin{array}{l}+ \text { My family seems to get along better } \\
\text { at home when I work. }\end{array}$ & 21 & 6 & 1.11 \\
\hline 62. - & $\begin{array}{l}\text { - My family would rather have me } \\
\text { stay at home. }\end{array}$ & 21 & 6 & 1.07 \\
\hline 35. - & $\begin{array}{l}\text { - I worry about whether my working } \\
\text { is good for my children (child). }\end{array}$ & 23 & 4 & 1.07 \\
\hline
\end{tabular}


TABLE VIII (continued)

Item

Frequency Mean

Low High Score

57. - I worry about whether babysitting

$22 \quad 5 \quad .92$

is good for my children (child).

68. - It's hard trying to hold down a job

$\begin{array}{lll}22 & 5 & .85\end{array}$

and raise children at the same

time.

24 items

Coefficient of reliability (odd-even): $r=.83$

(corrected for length of test)

Ten of the items failed to discriminate between high and low satisfaction because most of the sample gave similar responses to the item. Although not useful for building a discriminating scale, these items are most useful for describing the sample of mothers in terms of attributes that characterized the whole group. These items, which suggest some of the main sources of satisfaction for mothers, are given in Table IX. The frequency of agreement with each item is shown, as is the mean score for the item.

The idea that babysitters deserve commendation received almost universal agreement, which was interpreted as the mothers' perception of the sitters' job as a rather demanding one. While most of the mothers thought the children learned a lot, not all of them approved of everything they learned, such as "cussing, "so that the wording of Item 55 might be questioned. Items 60 and 70 
TABLE IX

FREQUENCY OF MOTHERS' AGREEMENT WITH ITEMS SHOWING HIGH ROLE SATISFACTION

\begin{tabular}{|c|c|c|c|c|}
\hline \multirow{2}{*}{ Item } & & \multicolumn{2}{|c|}{ Frequency } & \multirow{2}{*}{$\begin{array}{l}\text { Mean } \\
\text { Score }\end{array}$} \\
\hline & & Agree & Disagree & \\
\hline 42. + & $\begin{array}{l}\text { Babysitters deserve a lot of } \\
\text { credit. }\end{array}$ & 26 & 1 & 3.44 \\
\hline $55 .+$ & $\begin{array}{l}\text { Children learn a lot from stay- } \\
\text { ing in someone else's home } \\
\text { during the day. }\end{array}$ & 20 & 7 & 2.59 \\
\hline 60. + & $\begin{array}{l}\text { I get a better idea of what my } \\
\text { children are like from talking } \\
\text { to the babysitter. }\end{array}$ & 15 & 12 & 2.26 \\
\hline 52. - & $\begin{array}{l}\text { My neighbors don't approve of } \\
\text { my working. }\end{array}$ & 1 & 26 & 2.78 \\
\hline 70. + & $\begin{array}{l}\text { You usually can trust a sitter } \\
\text { to do a good job. }\end{array}$ & 15 & 12 & 2.22 \\
\hline
\end{tabular}

indicate that the majority of the mothers have confidence in the sitter and are interested in her observations. Item 52, regarding neighbors' disapproval of the mothers' working, received a somewhat higher rate of disagreement than was anticipated. The mothers felt their neighbors did approve for the most part, although five did not know what they thought.

By contrast, several other items indicated general sources of low satisfaction for mothers. These are shown in Table X. Item 34 received a negative response indicating that criticism was not a factor in the mothers' seeking employment. Items 44,75 and 
TABIE X

FREQUENCY OF MOTHERS' AGREEMENT WITH ITEMS SHOWING LOW ROLE SATISFACTION

\begin{tabular}{|c|c|c|c|c|}
\hline \multirow{2}{*}{ Item } & & \multicolumn{2}{|c|}{ Frequency } & \multirow{2}{*}{$\begin{array}{l}\text { Mean } \\
\text { Score }\end{array}$} \\
\hline & & Agree & Disagree & \\
\hline $34 .+$ & $\begin{array}{l}\text { I get criticized if I don't } \\
\text { work. }\end{array}$ & 6 & 21 & 1.33 \\
\hline 44. - & $\begin{array}{l}\text { It's hard to know what you } \\
\text { can expect of a sitter. }\end{array}$ & 20 & 7 & 1.22 \\
\hline 75. - & $\begin{array}{l}\text { I'd rather have a babysitter } \\
\text { come into my own home than } \\
\text { have my children go out. }\end{array}$ & 20 & 7 & 1.22 \\
\hline 43. - & $\begin{array}{l}\text { It bothers me not knowing } \\
\text { what goes on with the chil- } \\
\text { dren when they are at the } \\
\text { sitter's. }\end{array}$ & 16 & 11 & 1.88 \\
\hline $59+$ & $\begin{array}{l}+ \text { When I work, I'm better } \\
\text { organized at home. }\end{array}$ & 12 & 15 & 1.88 \\
\hline
\end{tabular}

(to some extent) 43, did indicate a concern with the unknown factors in the baby sitting relationship and a preference for care in the child's own home. Although the mothers were fairly evenly divided on how organized they are at home, they did not express strong feelings about this. Item 59, therefore, did not contribute significantly to the satisfaction level.

The 24 best discriminating items on Mother's Role Dependence are shown in Table XI. 
TABLE XI

SUMMA TED-RA TING SCALE OF MOTHERS'

ROLE DEPENDENCE (Mothers' RD)

\section{Item}

Frequency

Mean

Low High

Score

38. + My job depends on having a baby-
sitter.

$\begin{array}{lll}0 & 27 & 3.19\end{array}$

64. + Getting someone really reliable is

$126 \quad 3.19$ very difficult.
40. - I feel like almost everything depends on being able to make a good day care arrangement for my child (chil- dren).

53. + The money I make is important to me.

63. + I am careful not to impose on my babysitter.

86. + I hate having to change sitters.

87. - I could work a different shift and do without a sitter al together.

39. + I leave my child (children) with a babysitter because I, don't have

126

3.09 any choice.

67. + I make every effort to patch up mis understandings with the sitter.

94. + I have to work in order to make ends meet.

90. + I simply can't afford to lose my job.

89. - My working hours are flexible, and I can arrange them to suit my child $126 \quad 3.06$

$2 \quad 25 \quad 2.97$

$\begin{array}{lll}1 & 26 & 2.97\end{array}$

$\begin{array}{lll}3 & 24 & 2.87\end{array}$
care plans.

92. + My family couldn't get by if I didn't work.

$3 \quad 24 \quad 2.84$

$\begin{array}{lll}2 & 25 & 2.74\end{array}$

$\begin{array}{lll}7 & 20 & 2.55\end{array}$

$\begin{array}{lll}8 & 19 & 2.45\end{array}$

$\begin{array}{lll}8 & 19 & 2.32\end{array}$

$9 \quad 18 \quad 2.29$ 
TABLE XI (continued)

\begin{tabular}{|c|c|c|c|c|}
\hline \multirow{2}{*}{\multicolumn{2}{|c|}{ Item }} & \multicolumn{2}{|c|}{ Frequency } & \multirow{3}{*}{$\begin{array}{l}\begin{array}{l}\text { Mean } \\
\text { Score }\end{array} \\
2.29\end{array}$} \\
\hline & & Low & High & \\
\hline 96. & $\begin{array}{l}\text { - I have a list of alternates if this } \\
\text { arrangement fails. }\end{array}$ & 6 & 21 & \\
\hline 50. & $\begin{array}{l}\text { - I never have to worry about finding } \\
\text { another sitter. }\end{array}$ & 6 & 21 & 2.26 \\
\hline 93. & $\begin{array}{l}\text { - I can always get a sitter through an } \\
\text { agency. }\end{array}$ & 6 & 21 & 2.20 \\
\hline 81 & $\begin{array}{l}\text { - I don't want my child to get too at- } \\
\text { tached to a sitter. }\end{array}$ & 8 & 19 & 2.00 \\
\hline 71 & $\begin{array}{l}\text { - If necessary, I could quit work and } \\
\text { stay home. }\end{array}$ & 12 & 15 & 1.93 \\
\hline 98. & $\begin{array}{l}+ \text { I worry about being able to keep a } \\
\text { sitter. }\end{array}$ & 14 & 13 & 1.80 \\
\hline 77. & $\begin{array}{l}+ \text { You really have to work at it to } \\
\text { keep a sitter happy. }\end{array}$ & 15 & 12 & 1.74 \\
\hline 45. & - My children get along with anybody. & 15 & 12 & 1.51 \\
\hline 85. & $\begin{array}{l}\text { - I have a neighbor or a relative } \\
\text { available in an emergency. }\end{array}$ & 20 & 7 & 1.12 \\
\hline 80. & $\begin{array}{l}\text { - My babysitter has to be flexible } \\
\text { because sometimes I can't get } \\
\text { there on time. }\end{array}$ & 18 & 9 & 1.09 \\
\hline 91. & $\begin{array}{l}\text { - When my child (children) is (are) } \\
\text { sick, I am able to stay home. }\end{array}$ & 9 & 18 & 1.03 \\
\hline
\end{tabular}

\section{4 items}

Coefficient of reliability (odd-even): $r=.73$

(corrected for length of test)

Of the items for role dependence which did not discriminate between high and low, the following seemed to indicate general role dependence: 
TABLE XII

MOTHERS' ROLE DEPENDENCE

\begin{tabular}{lccc}
\hline Item & \multicolumn{2}{c}{$\begin{array}{c}\text { Frequency } \\
\text { Agree }\end{array}$} & $\begin{array}{c}\text { Mean } \\
\text { Score }\end{array}$ \\
\hline $37 .+\begin{array}{l}\text { A good babysitter is hard to } \\
\text { find. }\end{array}$ & 27 & 0 & 3.32 \\
$\begin{array}{l}58 .+ \text { I work in order to get ahead. } \\
72 . \quad\end{array}$ & 22 & 5 & 2.71 \\
$\quad \begin{array}{l}\text { Paying for child care costs } \\
\text { so much that it's hardly } \\
\text { worth my working. }\end{array}$ & 13 & 14 & 1.58 \\
\hline
\end{tabular}

The mothers agreed that finding a good sitter is difficult, but they seemed to feel that it was important they should do so if they want to work, and most of them felt that they needed to work if they wanted to get ahead. The agreement response to Item 72 was evenly distributed between both high and low scoring mothers, indicating that the problem of cost in relation to the wages they could command is an item of concern for all levels of dependence.

The items which indicated apparent role freedom are presented in Table XIII.

The majority of the mothers felt that their children's attitude toward the sitter was of importance; they did not want the children to continue an arrangement in which the children were not happy, although they did not like to make changes. 
TABLE XIII

MOTHERS' ROLE FREEDOM

\begin{tabular}{|c|c|c|c|c|}
\hline \multirow{2}{*}{ Item } & & \multicolumn{2}{|c|}{ Frequency } & \multirow{2}{*}{$\begin{array}{l}\text { Mean } \\
\text { Score }\end{array}$} \\
\hline & & Agree & Disagree & \\
\hline 66. & $\begin{array}{l}\text { - The most important thing } \\
\text { about a day care arrangement } \\
\text { is whether your child takes } \\
\text { to the sitter. }\end{array}$ & 24 & 3 & .80 \\
\hline 78 & $\begin{array}{l}\text { - I want my children to have } \\
\text { the experience of being with } \\
\text { different sitters. }\end{array}$ & 4 & 23 & 2.51 \\
\hline 82. & $\begin{array}{l}\text { - If my child did not like the } \\
\text { sitter I would change. }\end{array}$ & 19 & 8 & 1.03 \\
\hline 95 & $\begin{array}{l}+ \text { If I want a sitter, I have to } \\
\text { take what I can get. }\end{array}$ & 8 & 19 & 1.22 \\
\hline
\end{tabular}

Satisfaction with the Last Arrangement

The twenty-four best items in Satisfaction with Last Arrangement are shown in Table XIV.

TABLE XIV

SUMMA TED-RA TING SCALE OF MOTHERS' SA TISFACTION WITH THE LAST ARRANGEMENT (Mothers' LAS)

\begin{tabular}{lrrrr}
\hline Item & \multicolumn{2}{c}{$\begin{array}{c}\text { Frequency } \\
\text { Low }\end{array}$} & $\begin{array}{c}\text { Mean } \\
\text { Sigh }\end{array}$ & Score \\
\hline $21 . \quad$ - She expected too much of me. & 4 & 24 & 2.54 \\
$20 . \quad-\quad$ The sitter wouldn't tell me what & 4 & 24 & 2.48
\end{tabular}
went on with the children. 
TABLE XIV (continued)

\begin{tabular}{|c|c|c|c|c|}
\hline \multirow{2}{*}{ Item } & & \multicolumn{2}{|c|}{ Frequency } & \multirow{2}{*}{$\begin{array}{l}\text { Mean } \\
\text { Score }\end{array}$} \\
\hline & & Low & High & \\
\hline 22. + & $\begin{array}{l}\text { + My sitter and I kept on pretty good } \\
\text { terms. }\end{array}$ & 5 & 23 & 2.48 \\
\hline 31. & $\begin{array}{l}\text { - I couldn't count on her to help out } \\
\text { in an emergency. }\end{array}$ & 6 & 22 & 2. 48 \\
\hline 32. & $\begin{array}{l}\text { - It's hard trying to discuss my child } \\
\text { (children) with the babysitter.. }\end{array}$ & 4 & 24 & 2.48 \\
\hline 5. + & + She gave the children enough to do. & 7 & 21 & 2.42 \\
\hline 24. & - I felt she took advantage of me. & 6 & 22 & 2.42 \\
\hline 4. + & $\begin{array}{l}+ \text { I was satisfied with her housekeep- } \\
\text { ing and the way she kept the chil- } \\
\text { dren clean. }\end{array}$ & 6 & 22 & 2.42 \\
\hline $1 .+$ & $\begin{array}{l}+ \text { The babysitter and I enjoyed getting } \\
\text { together. }\end{array}$ & 7 & 21 & 2.30 \\
\hline 19. + & + I like the way she treats children. & 10 & 18 & 2.30 \\
\hline 7. + & $\begin{array}{l}+ \text { She took a real interest in my } \\
\text { child (children). }\end{array}$ & 9 & 19 & 2.27 \\
\hline 3. & $\begin{array}{l}\text { - We were too different in the way we } \\
\text { brought up children. }\end{array}$ & 9 & 19 & 2.24 \\
\hline 27. & $\begin{array}{l}\text { - I don't think she gave the children } \\
\text { enough attention. }\end{array}$ & 8 & 20 & 2.24 \\
\hline 10 & + She went out of her way to help me. & 10 & 18 & 2.21 \\
\hline 25. + & $\begin{array}{l}+ \text { If I ever had to change my plans } \\
\text { she was very flexible about it. }\end{array}$ & 9 & 19 & 2.12 \\
\hline 33. + & $\begin{array}{l}+ \text { She was the sort of person you } \\
\text { could tell your problems to. }\end{array}$ & 12 & 16 & 2.09 \\
\hline 9. + & + Her friendship meant a lot to me. & 12 & 16 & 2.03 \\
\hline 17 & $\begin{array}{l}+ \text { She took an interest in me per- } \\
\text { sonally. }\end{array}$ & 13 & 15 & 2.03 \\
\hline 29. + & $\begin{array}{l}\text { + My sitter really did more for me } \\
\text { than she had to. }\end{array}$ & 12 & 16 & 2.03 \\
\hline
\end{tabular}


TABLE XIV (continued)

\begin{tabular}{|c|c|c|c|c|}
\hline \multirow{2}{*}{ Item } & & \multicolumn{2}{|c|}{ Frequency } & \multirow{2}{*}{$\begin{array}{l}\text { Mean } \\
\text { Score }\end{array}$} \\
\hline & & Low & High & \\
\hline 8. + & $\begin{array}{l}+ \text { I liked the way she trained my } \\
\text { child (children). }\end{array}$ & 13 & 15 & 1.97 \\
\hline 14. + & $\begin{array}{l}+ \text { I would be willing to use the same } \\
\text { sitter again. }\end{array}$ & 12 & 16 & 1.97 \\
\hline 26. - & $\begin{array}{l}\text { - As time went on, I started looking } \\
\text { for a better arrangement with an- } \\
\text { other sitter. }\end{array}$ & 13 & 15 & 1.75 \\
\hline 13. + & + We had a lot in common. & 17 & 11 & 1.51 \\
\hline 16 & $\begin{array}{l}+ \text { The children (child) learned } \\
\text { some important things that they } \\
\text { wouldn't have gotten at home. }\end{array}$ & 17 & 11 & 1.45 \\
\hline
\end{tabular}

\section{4 items}

Coefficiency of reliability (odd-even): $r=.97$ (corrected for length of test)

The items which did not discriminate between high and low scoring mothers in this scale were predominately those intended to measure the mother's perception of the sitter's attitude toward her. See Table XV.

The mothers generally disagreed with the items in Table XV, indicating that they had few complaints to make regarding the sitter's approach to the relationship. The least satisfied mothers had no more incidence of agreement than the most satisfied. On the whole, they felt the sitter's charges were fair. 
TABLE XV

NON-DISCRIMINA TING LAS ITEMS FOR THE MOTHERS

\begin{tabular}{|c|c|c|c|c|}
\hline \multirow{2}{*}{ Item } & & \multicolumn{2}{|c|}{ Frequency } & \multirow{2}{*}{$\begin{array}{l}\text { Mean } \\
\text { Score }\end{array}$} \\
\hline & & Agree & Disagree & \\
\hline 11. & $\begin{array}{l}\text { - I didn't like the way she tried } \\
\text { to tell me what to do. }\end{array}$ & 3 & 25. & 2.48 \\
\hline 15. & $\begin{array}{l}\text { - I don't think she approved of } \\
\text { my working. }\end{array}$ & 4 & 24 & 2.27 \\
\hline 28 & $\begin{array}{l}\text { - I got tired of her telling me } \\
\text { her problems. }\end{array}$ & 3 & 25 & 2.48 \\
\hline 6. & $\begin{array}{l}\text { - I had trouble with my children } \\
\text { because the sitter spoiled } \\
\text { them. }\end{array}$ & 3 & 25 & 2.51 \\
\hline 12. & $\begin{array}{l}\text { - My last sitter charged too } \\
\text { much. }\end{array}$ & 2 & 26 & 2.57 \\
\hline
\end{tabular}

TABLE XVI

ITEMS RELATED TO CERTAIN ASPECTS OF THE LAST ARRANGEMENT (Mothers' LAS)

\begin{tabular}{|c|c|c|c|c|}
\hline \multirow{2}{*}{ Item } & & \multicolumn{2}{|c|}{ Frequency } & \multirow{2}{*}{$\begin{array}{l}\text { Mean } \\
\text { Score }\end{array}$} \\
\hline & & Agree & Disagree & \\
\hline 2 & $\begin{array}{l}\text { - I wasn't satisfied with the } \\
\text { kind of neighborhood. }\end{array}$ & 9 & 19 & 2.18 \\
\hline 18. & $\begin{array}{l}\text { - I wasn't satisfied with the } \\
\text { house and yard. }\end{array}$ & 12 & 16 & 1.72 \\
\hline 23. & $\begin{array}{l}\text { - The babysitter lived too far } \\
\text { away to be convenient. }\end{array}$ & 4 & 24 & 2.60 \\
\hline 30. & $\begin{array}{l}\text { - I didn't like the other chil- } \\
\text { dren who were in the baby } \\
\text { sitter's home. }\end{array}$ & 4 & 24 & 2.30 \\
\hline
\end{tabular}


There was some dissatisfaction with the physical aspects of the sitters' facilities, but, again, this was not confined to the low satisfaction mothers, and the majority were satisfied.

Only four mothers objected to the other children in the baby sitter's home. Two of these felt the children were too aggressive and two were uneasy because there were too many children and their children did not receive enough attention.

\section{Analys is of Data}

The study found only the most limited support for the hypothesis that continuity of the family day care arrangement is dependent in part on the mother's satisfaction with her role as mother and as day care user; on her perceived dependence on the use of day care; and on her satisfaction with the particular relationship and circumstances of the last arrangement.

As reported in Chapter III, the relationship between each of the scales and the number of weeks' duration of the arrangement was tested by Spearman Rank Order Correlation. These correlations were not statistically significantly different from zero at the 5 percent level and did not result in rejection of the null hypothes is.

Since the measures were reliable, the lack of association can not be attributed to low reliability and it was necessary to conclude that the value of the arrangement to the mothers alone, by itself, 
and as measured, did not account for the duration of arrangements for the mothers in the sample.

A scalar relationship was found, however, between whether the mothers got what they were looking for in an arrangement and their satisfaction with a particular arrangement (LAS):

$\begin{array}{lccc} & \text { Get } & \text { Not Get* } \\ \text { High LAS } & 12 & 1 & \text { (13) } \\ \text { Low LAS } & 6 & 9 & \text { (15) } N=28\end{array}$

With an almost zero cell, the distribution shows an association that is somewhat scalar rather than a pattern of chance expectancy. The difference in proportions is statistically significant at the five percent level. It can be seen that all but one of those mothers who said they did not find what they were looking for in an arrangement scored low on satisfaction (LAS), while all but one of those with high satisfaction did report getting what they were looking for. "Getting" was not necessarily accompanied by high satisfaction, but it tended to be $(\mathrm{p}<.05)$.

These results are not surprising. Indeed, they lend confidence

* Responses to Item 15 in the interview schedule served to dichotomize the mothers in terms of "getting" or "not getting." A respondent was classified as "not get" if her last arrangement lacked one or more of the characteristics which she had indicated as being important to her, or if she only got "partially" what she was looking for, in two or more such characteristics. 
in the validity of the data, since having one's expectations met was conceived as fundamental to satisfaction.

An additional finding was that the mothers' role dependence scores showed an inverse scalar pattern in relation to getting what they were looking for in an arrangement.

Get Not Get

$\begin{array}{lrll}\text { High RD } & 7 & 7 & \\ \text { Low RD } & 10 & 3 & \mathrm{~N}=27\end{array}$

Most mothers who reported not getting what they were looking for in an arrangement, scored high on Role Dependence, i.e., they tended to see themselves as having little choice about working and as having to take what they could get in a sitter. On the other hand, among those 13 mothers characterized by a sense of freedom of choice (low dependence), all but three reported getting what they were looking for.

This latter scalar pattern was not anticipated and is especially interesting. The Role Dependence scale was designed to measure the value of the arrangement arising from the degree to which it was seen as the only available alternative. It was a low degree of role dependence however that was associated with a prime condition of satisfaction, that of getting what the mother was looking for in an ar rangement. 
The relationship between these variables is further clarified by Guttman scale analys is of the mothers' dichotomized responses to the four variables:

A. Getting vs. not getting what the mother was looking for in an ar rangement.

B. High vs. Low satisfaction with the particular arrangement (LAS).

C. Role Freedom vs. Role Dependence (reversing the signs for the Role Dependence scale scores, to conform to the way in which freedom of choice operated.)

D. Work Role Freedom vs. Work Role Dependence. (See Tables XVIII and XIX.)

The scale (Table XVII) had a coefficient of reproducibility of .92 and met minimum standards for scalograms except for the few number of items involved. This scale gave five types of mothers in which 21 out of 27 mothers were perfect scale types, exceeding the expected frequency of scale types at $p=.0002$ (Schuessler, 1961). Thus the scale presents a picture of typicality for the sample of mothers, in rank-order degree from high to low on the dimension of Role Freedom and Satisfaction.

The scale also presents a newly constructed independent variable which orders the components and conditions of satisfaction 
among the mothers. The scalogram reveals that a mother who perceived herself as having a high degree of freedom of choice (Role Freedom) also was satisfied with her arrangement (LAS), and got what she was looking for in an arrangement. A mother who failed to get what she was looking for, scored low also on LAS and Role Freedom (RF).

TABLE XVII

MOTHERS' SATISFACTION AND ROLE FREEDOM:

A GUTTMAN SCALE

\begin{tabular}{|c|c|c|c|c|c|c|c|c|}
\hline \multicolumn{2}{|c|}{ Types } & $\begin{array}{c}\mathrm{D} \\
\text { WRF }\end{array}$ & $\begin{array}{c}\mathrm{C} \\
\mathrm{RF}\end{array}$ & $\begin{array}{c}B \\
\text { LAS }\end{array}$ & $\begin{array}{c}\text { A } \\
\text { Get }\end{array}$ & $\begin{array}{c}f \\
\text { Scale } \\
\text { Types }\end{array}$ & $\begin{array}{c}f \\
\text { Non- } \\
\text { Scale } \\
\text { Types }\end{array}$ & $\begin{array}{l}\text { No: } \\
\text { Errors }\end{array}$ \\
\hline \multirow[t]{4}{*}{ High } & 5 & + & + & + & + & 4 & 2 & 2 \\
\hline & 4 & - & + & + & + & 4 & 0 & \\
\hline & 3 & - & - & + & + & 3 & 0 & \\
\hline & 2 & - & - & - & + & 4 & 0 & \\
\hline \multirow[t]{4}{*}{ Low } & 1 & - & - & - & - & 6 & 4 & 7 \\
\hline & & & & \multicolumn{2}{|c|}{ Total } & 21 & $6=27$ & 9 \\
\hline & + & 9 & 13 & 12 & 17 & & & \\
\hline & - & 18 & 14 & 15 & 10 & & & \\
\hline
\end{tabular}

Reproducibility $=.92$

Minimum Marginal Rep. $=.59$

Observed frequency of Scale Types $=21 ; \mathrm{z}=3.528 ; \mathrm{p}=.0002$

Expected frequency of Scale Types $=11.4$ 
The dichotomized data for WRF (work role freedom) was obtained from two Guttman scale analyses of similar items (Tables XVIII, XIX). The two scalograms showed perfect correlation and reliability for the dichotomized responses.

SCALOGRAM B SCALOGRAM A

High: type 5, 4

Low: type $3,2,1$ High: type 4, 3 Low: type 2, 1

\begin{tabular}{|c|c|}
\hline 18 & 0 \\
\hline 0 & 9 \\
\hline
\end{tabular}
$N=27$

TABLE XVIII

MOTHERS' WORK ROLE DEPENDENCE: SCALOGRAM A

\begin{tabular}{|c|c|c|c|c|c|}
\hline & $\begin{array}{l}\text { :ale } \\
\text { ype }\end{array}$ & $\begin{array}{l}C \\
90\end{array}$ & $\begin{array}{l}B \\
92\end{array}$ & $\begin{array}{c}A \\
94 \text { or } 71\end{array}$ & $f$ \\
\hline \multirow[t]{3}{*}{ High } & 4 & + & + & + & 10 \\
\hline & 3 & - & + & + & 8 \\
\hline & 2 & - & - & + & 5 \\
\hline \multirow[t]{4}{*}{ Low } & 1 & - & - & - & 4 \\
\hline & & & & & $N=27$ \\
\hline & + & 10 & 18 & 23 & \\
\hline & - & 17 & 9 & 4 & \\
\hline
\end{tabular}

Reproducibility $=1.00$

Minimum Marginal Rep. $=.70$

Items:

A 71 (Disagree to: "If necessary I could quit work and stay home." or 94 (Agree to: "I have to work in order to make ends meet."

B 92 Agree to: "My family couldn't get by if I didn't work."

C 90 Strongly agree to: 'I simply couldn't afford to lose my job." 
TABLE XIX

MOTHERS' WORK ROLE DEPENDENCE: SCALOGRAM B

\begin{tabular}{|c|c|c|c|c|c|c|c|c|}
\hline & $\begin{array}{l}\text { Scale } \\
\text { Type }\end{array}$ & $\begin{array}{c}D \\
71\end{array}$ & $\begin{array}{l}C \\
92\end{array}$ & $\begin{array}{c}B \\
94\end{array}$ & $\begin{array}{c}A \\
53\end{array}$ & $\begin{array}{c}f \\
\text { Scale } \\
\text { Types }\end{array}$ & & $\begin{array}{c}f \\
\text { Non- } \\
\text { Scale } \\
\text { Types }\end{array}$ \\
\hline \multirow[t]{4}{*}{ High } & 5 & + & + & + & + & 13 & & \\
\hline & 4 & - & + & + & + & 5 & & \\
\hline & 3 & - & - & + & + & 2 & & \\
\hline & 2 & - & - & - & + & 3 & & 3 \\
\hline \multirow[t]{4}{*}{ Low } & 1 & - & - & - & - & 1 & & - \\
\hline & & & & & Total & 24 & + & $3=27$ \\
\hline & + & 16 & 18 & 20 & 26 & & & \\
\hline & - & 11 & 9 & 7 & 1 & & & \\
\hline
\end{tabular}

Reproducibility $=.97$

Minimum Marginal Rep. $=.75$

Items :

A 53 Agree to: "The money I make is important to me."

B 94 Agree to: "I have to work in order to make ends meet."

C 92 Agree to: "My family couldn't get by if I didn't work."

D 71 Disagree to: "If necessary, I could quit work and stay home."

Findings on the Relations hip Between Mothers' Dependence, Satisfaction, and the Continuity of the Family Day Care Arrangement

The Guttman scale shown in Table XVII which linked high satisfaction to low dependence, or a sense of freedom of choice, was 
found associated with arrangements that were of longer duration. It can be expressed thus:

\begin{tabular}{ll|l|}
\multirow{2}{*}{ Satisfaction } & \multicolumn{2}{c}{ Hependence } \\
How & Digh & Low \\
\cline { 2 - 3 } & Discontinuity & Continuity \\
\hline
\end{tabular}

This relationship by Spearman Rank Order Correlation was statistically significantly different from zero at the one percent level. Table XX, shows the high, type 5 , mothers having longer lasting arrangements, while type 1 mothers have shorter arrangements. In general, the higher the scale type the longer the arrangement, Rho $=.49 ; \mathrm{p}<.01$ (corrected for ties).

\section{TABLE XX}

DURATION OF ARRANGEMENT BY SCALE TYPE ON THE SCALOGRAM OF MOTHERS' SATISFACTION AND ROLE FREEDOM

\begin{tabular}{llccccc}
\hline & \multicolumn{2}{l}{$\begin{array}{l}\text { Scale Types } \\
\text { High }\end{array}$} & & & Low & \\
Duration & 5 & 4 & 3 & 2 & 1 & \\
\hline Long * & 5 & 2 & 0 & 2 & 1 & 10 \\
Medium *** & 0 & 1 & 3 & 1 & 4 & 9 \\
Short *** & $\frac{1}{6}$ & $\frac{1}{4}$ & 0 & $\frac{1}{4}$ & $\frac{5}{10}$ & $\mathrm{~N}=27$ \\
Totals & 6 & 4 & 3 & 4 & & 8 \\
\hline
\end{tabular}

Rho $=.49 ; \mathrm{p}<.01$ (corrected for ties)

* 12 weeks or over; *** $6-8$ weeks; *k* 4 weeks and under 
This relationship can be summarized.more simply as is shown in Table XXI.

TABLE XXI

SIMPLIFIED PRESENTATION OF TABLE XX

Scale Type

5 and 4

Duration of the Arrangement
Low Role Dependence High Role Freedom

High Sa tisfaction
3,2 , and 1

High Role Dependence Low Role Freedom

Low Satisfaction

\begin{tabular}{lrrr}
\hline Long * & 7 & 3 & 10 \\
Short *** & 3 & 14 & 17 \\
& & $\mathrm{~N}=27$ \\
\hline
\end{tabular}

* 12 weeks or over

*** 8 weeks or under

\section{Summary}

The findings, therefore, lend support to the usage and modification of Thibaut and Kelley's Model of CL and CL alt in measuring the mothers' evaluative attitudes toward their day care arrangements. Those mothers who perceived themselves as having considerable freedom in their working roles and suitable alternatives for their arrangernents reflected their freedom of choice by (1) making arrangements that at least approximate their expressed

* Comparison level and comparison level for alternatives. See Chapter II. 
desires and (2) expressed a higher rate of satisfaction with their last arrangement. Furthermore the arrangements for this group of mothers tended to be relatively long-lasting.

Validity of findings is further substantiated by an association between the mothers' work role freedom and their maintenance behavior. Mothers who saw themselves as highly dependent on their work role also tended to see the sitters as power figures and themselves as needing to accommodate the sitters. Of the 19 mothers who felt that it was their responsibility to maintain the arrangement. (See Table VI), 15 also rated high in work role dependence, as illus trated in Table XXII.

TABLE XXII

MOTHERS' ACCOMMODATION ORIENTATION BY WORK ROLE DEPENDENCE

\begin{tabular}{|c|c|c|c|}
\hline WRD & Accommodating & Non-Accommodating & \\
\hline+ & 15 & 3 & 18 \\
\hline \multirow[t]{2}{*}{-} & 4 & $\underline{5}$ & 9 \\
\hline & 19 & 8 & $N=27$ \\
\hline
\end{tabular}

$\mathrm{z}=1.6555$

$\mathrm{p}=.049$

This finding also correlates with the analysis of termination procedures. As indicated, mothers did not take the initiative in 
terminating an arrangement, even when this was not entirely satisfactory to them; rather termination was often initiated by the sitter to whom the mothers also attributed most of the power.

The study further showed that those arrangements which can be termed successful from the standpoint of satisfaction and duration contained an element of reciprocity in which both intrinsic and extrinsic needs were met. Although most of the mothers would have preferred a sitter in the home or a day care center, those who did utilize family day care arrangements indicated sources of satisfaction outside the immediate area of child care. The mothers, who expressed themselves as dissatisfied with the arrangement (in general) but nevertheless pointed out areas of particular satisfactions, illustrate this point. If the findings of this study may be taken to mean that family day care is a potential source of satisfactory day care--and will continue to fill a community need--perhaps future research could be directed toward exploring the areas of satisfaction/dissatisfaction in greater depth to highlight areas of social work intervention. 


\section{CHAPTER V}

\section{THE SITTERS}

\section{Introduction and Review of the Literature}

Of equal concern in this study of private family day care are the sitters, the women who provide care on a regular basis in their own homes to the children of working mothers. As has been previously stated, over half a million children under six are cared for in someone else's home by a non-relative during all or part of the mother's working hours. The literature concerned with day care repeatedly emphasizes the need to know more about the many informal child care arrangements. Relatively little is known about the women who give child care, the sitters. A thorough search of the literature reveals only two studies which focus in depth upon the sitters. The present research may be seen in relation to these two other studies. One is a study of "mother substitutes." (Perry, 1961). The other is a report of a demonstration project called the Day Care Exchange Project (Collins, 1966).

Perry's study is concerned with sitters as this study has defined them, but his sample included other types of child care arrangements as well. Perry used the term "mother substitutes" and defined it as anyone giving care to children while the mother 
was employed. In Spokane, Washington in 1958, Perry interviewed 104 working mothers and 82 of their mother substitutes. He found that usually sitters cared for only a few children at one time, generally four or less. They did not have extensive experience as mother substitutes. Fifty-four percent reported they had been doing child care work for two to four years and twenty percent for four or more years. But the majority of the sitters viewed their work role as permanent or semi-permanent. Perry felt this might be taken as evidence for the tentative judgment that the employed mother-mother substitute relationships were relatively stable and mutually satisfactory. In the sample studied by Perry the child care arrangements had been relatively stable and permanent over time and were associated with satisfaction.

The Day Care Exchange Project in nor thwest Portland has been attempting to bring together sitters who want to care for children and mothers who want private family day care for their offspring. This is done by identifying women who are giving day care and who, in addition, are thought to be "in the know" about who needs day care and who is giving care in their neighborhood. Social work consultation is provided these women, called Day Care Neighbors, to encourage them in their natural neighboring role of "matchmaking" between mothers and sitters. Thus, the informal social system operating in the neighborhood is used to facilitate the making of 
child care arrangements to the advantage of both the sitters and the mothers. Intervention is focused upon improving the interaction rather than the creation of a service which would in effect compete with it (Collins, 1966).

In addition, requests for day care received by the central office of the Day Care Exchange Project are turned over to the Day Care Neighbors who help the party make an arrangement. In this way arrangements are made between women who otherwise would not know each other. In the present study, eight of the eleven sitters from the Day Care Exchange Project sample reported being strangers to the mothers in the arrangements studied.

The Day, Care Exchange Project has encountered a peculiar reluctance on the part of women to admit that they provide day care. In a three year period the Day Care Exchange Project has had contact with 122 women who were giving or wished to give day care. Of these, 64 percent had made one arrangement during this period and 36 percent had made multiple arrangements (Collins, 1966). The project director felt that even with extensive surveying many women in the private family day care system of the nor thwest Portland area were uncounted. Sitters tend to minimize the extent to which they provide care. They tend to avoid labeling themselves or being labeled as sitters. This is perhaps due to the low status connotation connected with babysitting. It is the impression of the Day 
Care Exchange Project staff that there are many sitters who have given child care for a number of years with apparent satisfaction, where others have reported frustration especially with the turnover in children cared for. Discontinuity of care was a major source of dissatisfaction for the day care givers studied by the Day Care Exchange Project. Discontinuity affected the sitters in that they could not rely upon giving day care for a steady income. Sitters perceived termination of arrangements as a form of personal rejection in some cases (Collins, 1966).

Most other published information about sitters consist of magazine and newspaper "shocker" articles, essentially describing situations of cruelty and neglect intended to create concern and awareness and to elicit support from the American public for use of federal funds to provide for day care centers (Ross, 1967; Robbins, 1966; Bagdikian, 1966). There are many articles published in popular magazines aimed at the teenager and instructional in nature on how to be a good babysitter.

\section{Characteristics of the Sample}

$\underline{\text { Number }}$

The sample studied consisted of 23 sitters involved in 27 babysitting arrangements. 
$\underline{\text { Age }}$

The 23 sitters tended to be young mothers more than grandmotherly types, only five being over 50 .

Marital Status

Eighteen sitters were married. Five sitters reported no hus band in the home. Two of these sitters were recently separated. Separation played a part in the reason for babysitting in one instance and in the reason for terminating babysitting and taking outside employment in another ins tance.

Number of Children

All sitters in the sample had children of their own. Nineteen of the sitters had at least one child age ten or under in the home. Of these 14 had at least one pre-school age child and only four sitters had all adult children out of the home.

\section{Annual Family Income}

The total annual family income ranged from under $\$ 1,000$ to $\$ 10,000$. The median was $\$ 4,500$. Three sitters were the sole support of the family and these three received Social Security, Veterans benefits, or ADC assistance. Sitters' husbands were mostly 
employed in skilled and semi-skilled jobs. One was a minister. Sitters' incomes from giving day care did not contribute appreciably to the total family income in any instance. No sitter reported earning more than $\$ 166.00$ monthly for babysitting in the month prior to the interview.

\section{Education}

The majority of the sitters had completed or had had some high school education. Only four had had additional education or training.

Educational level of sitters

$$
\begin{aligned}
& N=23 \quad \text { grade school only } \quad I \\
& \text { some high school } 8 \\
& \text { high school graduate } \quad 10 \\
& \text { high school graduate, } 2 \\
& \text { plus special training } \\
& \text { college work } 1 \\
& \text { college graduate } \quad 1
\end{aligned}
$$

Previous Work Experience

Twenty-one sitters had worked outside the home in the past.

Sitters' occupations in previous outside employment

$$
N=21 \quad \text { office work } 6
$$

waitress 3 


$\begin{array}{ll}\text { maid or day work } & 3 \\ \text { factory work } & 3 \\ \text { florist } & 1 \\ \text { welfare caseworker } & 1 \\ \text { occupation unknown } & 4\end{array}$

\section{Previous Babysitting Experience}

Sitters were asked how long they had been doing babysitting. The responses ranged from two weeks to 17 years. The median was three years. It is felt that the wording of the interview question tapped a broader aspect of babysitting and is not indicative of the length of time sitters have been giving private family day care on a regular basis in all cases.

\section{Characteristics of the Last Arrangement}

$\underline{\text { Number }}$

Twenty-three sitters were interviewed concerning 27 babysitting arrangements, involving 25 mothers and 54 children. The sample of sitters was obtained from two sources: the mothers interviewed and the referrals from the Day Care Exchange Project. 
Duration of Arrangement

The duration of arrangements reported by sitters ranged from one day to 117 weeks. The median duration was seven weeks. The median duration for the sample obtained indirectly from the welfare department which included 16 arrangements was eight weeks, while the median duration for the Day Care Exchange Project sample of 11 arrangements was four weeks.

\section{Children of These Arrangements}

The number of children from one family in the care of one sitter ranged from one to six; most arrangements were for one or two children from a family.

$\begin{array}{lcc} & \begin{array}{c}\text { Number of } \\ \text { Children }\end{array} & \begin{array}{c}\text { Number of } \\ \text { Arrangements }\end{array} \\ \text { Number of children } & 2 & 10 \\ \text { per arrangement in } & 3 & 11 \\ \text { care of one sitter } & 4 & 4 \\ & 5 & 1 \\ & 6 & 1\end{array}$

Of the 54 children involved in these 27 arrangements, 42 were of pre-school age. Twelve were from ages seven to sixteen. The care of the latter was limited to before and/or after school and on holidays. 
Sitters Job Description

The sitter gave child care five days per week. The hours the sitters gave care in 20 arrangements were regular and ranged from five to eleven and one half hours per day; the average was nine hours per day. In seven cases the hours of the arrangements varied depending upon the mother's irregular working hours and/or including part of some days at a nursery school or kindergarten for the children.

No standard rate for child care was found even though it was commonly felt in the community that there was a going rate. Fees ranged from $\$ 1.00$ per day to $\$ 4.00$ per day for a day varying from five to eleven and one half hours and for one to six children. No sitter charged an hourly rate; although hourly pay figures out to about 20 cents per hour. One sitter stated that she charged according to the mother's circumstances. Her fee was less for a mother who was the sole support of a family than for a family. in which both the husband and wife worked. Another sitter took only a token fee from a mother who was a personal friend. Some variation in fee can be atributed to the fact that some mothers provided food for the child in lieu of direct money payment. 
Formation of the Arrangement

How mothers and sitters got together:

Referred to each other through a mutual 8 friend or acquaintance

Were friends $\quad 8$

Referred through the DCEP 6

Sitter was a former employee of mother $\quad 1$

Got together through casual conversa- $\quad 3$ tions

Through mutual caseworker 1

$\mathrm{N}=27$

By and large, sitters and mothers got together through the informal social system of the neighborhood. Six referrals came through the Day Care Exchange Project, which, as previously explained, attempted to facilitate use of this informal system.

Relationship

Sitters were asked whether they and the mothers were friends, acquaintances, or strangers when the arrangement began. The sample was about equally divided.

$\begin{array}{llr} & \text { Friends } & 8 \\ & \text { Acquaintances } & 8 \\ N=27 & \text { Strangers } & 11\end{array}$


A difference in the responses from the two sources of the sample was noted.

\begin{tabular}{|c|c|c|}
\hline & DCEP & MCPW \\
\hline Friends and Acquaintances & 3 & 13 \\
\hline Strangers & 8 & 3 \\
\hline
\end{tabular}

As has been previously noted, the high number of arrangements among strangers in the group from the Day Care Exchange Project is related to the influence of the Project which operates precisely for the purpose of facilitating the making of arrangements among strangers.

\section{Maintenance Behavior}

Sitters were asked what it takes to keep a babysitting arrangement going. Their responses were rated independently by three judges âs to whether the sitter saw herself or the mother as having to do the accommodating in the relationship. There was initial complete agreement on 13 responses. The remaining ten responses on which consensus was not initially reached were reviewed and agreement was reached on them. 
The Orientation of the Sitters

Sitter sees mother as having balance of power and takes responsibility for accommodating the mother. $\quad N=4$

Verbatim excerpts:

It is a cooperative effort between the mother and sitter. A sitter needs equipment for the children and to keep them occupied.

It takes patience and concentration on the sitter's part. You have to bend and excuse other people's children.

It takes a lot of patience and cooperation of the mother.

You need an adequate place for the children to play.

You have to work out the money problems. You have to be good to the kids. The kids need to like you.
Sitter sees herself as having balance of power and expects mother to accommodate to sitter's expectations. $N=19$

There can be no boss if the arrangement works out. Sitter and mother have to respect each other.

There are serious problems only when the mothers don't cooperate.

You have to be able to treat the kids like you do your own. You have to get your money on time.

Pay me when you're supposed to.

You have to keep the children happy and get enough pay.

Nineteen of the 23 sitters saw themselves as having the balance of power. They expected the mothers to accommodate to their expectations.

$\underline{\text { Reasons for Sitting }}$

Frequency of Mention

Earning extra money 18

Loving children 


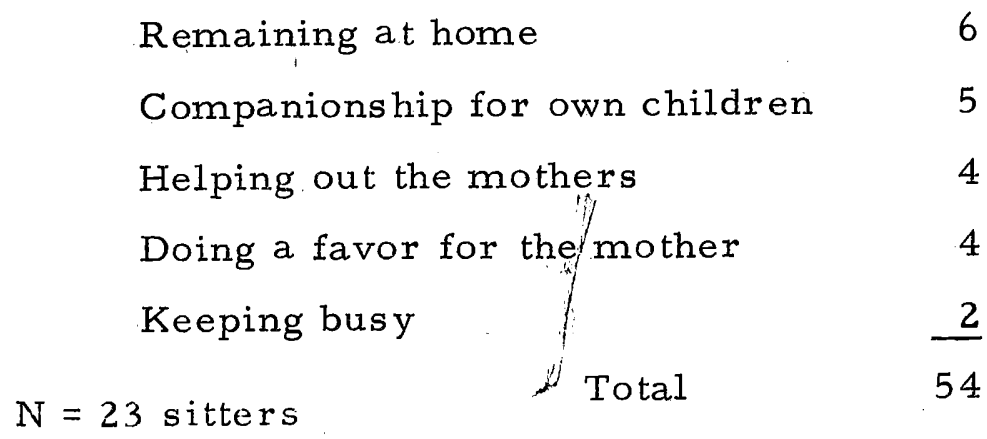

6

4

4

$\underline{2}$

54

It appeared that the sitters in the sample were basically child and family oriented women. Earning "pin money" was a part of the motivation in giving child care but only two sitters who were involved in five of the arrangements studied could be classified as being "in the business" of giving day care. One of these exceptions even carried her babysitting business to the extent of sub-contracting with an elderly lady who came into the sitter's home to substitute while the sitter worked a part-time shift as a waitress.

\section{Termination of the Arrangement}

Sitters were asked why the arrangement terminated and whose idea it was to terminate. The responses to both questions were classified as follows:

Reasons for Termination

Changes in sitter's situation
11

\section{Who Initiated \\ Termination}




$\begin{array}{lll}\begin{array}{l}\text { Changes in mother's } \\ \text { need }\end{array} & \begin{array}{l}\text { mother } \\ \text { sitter } \\ \text { mutual }\end{array} & =7 \\ & =1\end{array}$
$\begin{aligned} & \text { Sitter became dissatis - } \\ & \text { fied with the arrange- } \\ & \text { ment }\end{aligned}$
$\begin{aligned} & \text { Mutual planned ter- } \\ & \text { mination }\end{aligned}$
\[ \begin{array}{l}\text { mother }=1 \\ N=27\end{array} \]

Thus, reasons reported for termination were largely due to circumstance rather than to dissatisfaction. The sample was almost evenly divided as to whether the change in circumstance was on the part of the mother or the sitter. Sitters more frequently perceived themselves as having initiated termination. It can be noted that in all instances where sitters became dissatisfied with the arrangement, they also initiated termination.

\section{Post-Arrangement Activity of Sitters}

Sixteen of the sitters discontinued their role as a day care giver for the following reasons:
to stay at home
to take out-of-home employment 4
other than child care
to give foster care 2
to give child care in child's home 2

$$
\text { Sub-total } \quad 16
$$


Seven of the sitters continued to perform the role of private family day care giver.

An analysis of the post-arrangement activity of sitters shows that approximately one third of the 23 sitters continued performance of the family day care role, while an additional third turned to other forms of employment or child care.

\section{The Independent Variables}

Of the 35 scale items relating to sitters' satisfaction with the last arrangement, 24 were selected on the basis of their ability to discriminate between sitters who scored high and low on the items. This is described in Chapter III. The 24 best scale items on sitters' satisfaction with the last arrangement are shown in Table XXIII.

\section{TABLE XXIII}

SUMMA TED-RA TING SCALE OF SITTERS' SA TISFACTION WITH THE LAST ARRANGEMENT (Sitters' LAS)

\begin{tabular}{|c|c|c|c|}
\hline \multirow{2}{*}{ Item } & \multicolumn{2}{|c|}{ Frequency } & \multirow{2}{*}{$\begin{array}{l}\text { Mean } \\
\text { Score }\end{array}$} \\
\hline & Low & $\mathrm{High}$ & \\
\hline 14. - The children weren't happy here. & 2 & 25 & 3.22 \\
\hline $\begin{array}{l}\text { 19. - The mother didn't think much of } \\
\text { people who give child care. }\end{array}$ & 3 & 24 & 3.11 \\
\hline $\begin{aligned} 1 .+ \text { She took a real interest in her child } \\
\text { (children). }\end{aligned}$ & 5 & 22 & 3.07 \\
\hline
\end{tabular}


TABLE XXIII (continued)

\begin{tabular}{|c|c|c|c|c|}
\hline \multirow{2}{*}{ Item } & & \multicolumn{2}{|c|}{ Frequency } & \multirow{2}{*}{$\begin{array}{l}\text { Mean } \\
\text { Score }\end{array}$} \\
\hline & & Low & $\mathrm{High}$ & \\
\hline 6: & $\begin{array}{l}\text { - The mother expected too much from } \\
\text { me. }\end{array}$ & 4 & 23 & 3.03 \\
\hline $3 .+$ & $\begin{array}{l}+ \text { I like the way the mother treats } \\
\text { children. }\end{array}$ & 4 & 23 & 3.00 \\
\hline 28. & - The children were too much for me. & 4 & 23 & 2.96 \\
\hline 32. & $\begin{array}{l}\text { - I got tired of the mother telling me } \\
\text { her problems. }\end{array}$ & 5 & 22 & 2.92 \\
\hline 4. & $\begin{array}{l}\text { - I had trouble with her children (child) } \\
\text { because they were spoiled. }\end{array}$ & 5 & 22 & 2.92 \\
\hline $25+$ & $\begin{array}{l}+ \text { The mother and I kept on pretty } \\
\text { good terms. }\end{array}$ & 4 & 23 & 2.88 \\
\hline 16. & $\begin{array}{l}\text { - I felt like the mother took advantage } \\
\text { of me. }\end{array}$ & 6 & 21 & 2.88 \\
\hline 31 & $\begin{array}{l}\text { - I don't think the mother was con- } \\
\text { cerned enough about her children. }\end{array}$ & 5 & 22 & 2.85 \\
\hline 34. & $\begin{array}{l}\text { - I became less satisfied with the } \\
\text { children. }\end{array}$ & 5 & 22 & 2.85 \\
\hline $34 \mathrm{~A}$. & $\begin{array}{l}\text { - It was hard trying to discuss her } \\
\text { child (children) with her. }\end{array}$ & 7 & 20 & 2.85 \\
\hline 30 & + I liked the way her children behaved. & 4 & 23 & 2.81 \\
\hline 15 & $\begin{array}{l}+ \text { The mother really cared how I felt } \\
\text { about things. }\end{array}$ & 4 & 23 & 2.81 \\
\hline 13. + & $\begin{array}{l}\text { The mother and I enjoyed getting } \\
\text { together. }\end{array}$ & 5 & 22 & 2.81 \\
\hline 21 & $\begin{array}{l}\text { - I became less satisfied with the } \\
\text { mother. }\end{array}$ & 6 & 21 & 2.81 \\
\hline 22. + & $\begin{array}{l}\text { + I would be willing to take her child } \\
\text { again. }\end{array}$ & 4 & 23 & 2.77 \\
\hline 23. - & $\begin{array}{l}\text { - The mother and I were too different } \\
\text { in the way we bring up children. }\end{array}$ & 8 & 19 & 2.74 \\
\hline
\end{tabular}


TABLE XXIII (continued)

\begin{tabular}{|c|c|c|c|c|}
\hline \multirow{2}{*}{ Item } & & \multicolumn{2}{|c|}{ Frequency } & \multirow{2}{*}{$\begin{array}{l}\text { Mean } \\
\text { Score }\end{array}$} \\
\hline & & Low & High & \\
\hline 17. + & + The children were neat and clean. & 6 & 21 & 2.70 \\
\hline 18. & $\begin{array}{l}\text { - I don't think the mother gave her } \\
\text { children enough attention. }\end{array}$ & 9 & 18 & 2.55 \\
\hline 2. - & $\begin{array}{l}\text { - I was really ready to give the chil- } \\
\text { dren up. }\end{array}$ & 7 & 20 & 2.48 \\
\hline 10. + & + I was sorry to see the children go. & 11 & 16 & 2.14 \\
\hline
\end{tabular}

24 items; $N=27$ sitters

Coefficient of reliability (odd-even): $r=.95$

(corrected for length of test)

Eleven items failed to discriminate between high and low satisfaction with the last arrangement because most of the sample gave similar responses to these items. Although not useful for building a discriminating scale, these items were most useful for describing the sample of sitters in terms of attributes that characterized the whole group. These items, which suggested some of the main sources of satisfaction for sitters, are given in Table XXIV. The frequency of agreement with each item is shown as is the mean score for the item.

Sitters tended to be satisfied with the hours they gave child care and with the payment they received. Sitters were concerned about the mothers' perception of them in their role as day care 
TABLE XXIV

SOURCES OF SATISFACTION FOR SITTERS

\begin{tabular}{|c|c|c|c|c|}
\hline \multirow{2}{*}{ Item } & & \multicolumn{2}{|c|}{ Frequency } & \multirow{2}{*}{$\begin{array}{l}\text { Mean } \\
\text { Score }\end{array}$} \\
\hline & & Agree & Disagree & \\
\hline 5. - & $\begin{array}{l}\text { - I worried about whether the } \\
\text { mother thought I was doing } \\
\text { all right. }\end{array}$ & 24 & 3 & 3.07 \\
\hline 8. + & $\begin{array}{l}+ \text { The mother's friendship meant } \\
\text { a lot to me. }\end{array}$ & 21 & 6 & 2.77 \\
\hline 24. & $\begin{array}{l}\text { The mother didn't pay me } \\
\text { enough. }\end{array}$ & 6 & 21 & 2.77 \\
\hline 29. + & $\begin{array}{l}+ \text { I was satisfied with the hours } \\
\text { I took care of the child. }\end{array}$ & 21 & 6 & 2.66 \\
\hline 26. + & + I was satisfied with the money. & 22 & 5 & 2.62 \\
\hline 9. + & $\begin{array}{l}+ \text { The mother took an interest } \\
\text { in me personally. }\end{array}$ & 19 & 8 & 2.51 \\
\hline $11 .+$ & $\begin{array}{l}\text { The mother and I had a lot in } \\
\text { common. }\end{array}$ & 14 & 13 & 2.14 \\
\hline
\end{tabular}

giver. The personal relationship between mothers and sitters was also valued by the sitters.

The 24 best discriminating items on the sitters role dependence scale are shown in Table XXV.

Seven items failed to discriminate between the high and low dependent sitters; that is all sitters tended to respond in a similar manner to these items. These non-discriminatory items are listed in Table XXVI. Like the non-discriminatory items in Table XXIV these items are useful in describing the sample as a whole. 
TABLE XXV

SUMMA TED-RA TING SCALE OF SITTERS' ROLE

DEPENDENCE (Sitters' RD)

\begin{tabular}{lll}
\hline \multirow{2}{*}{ Item } & $\begin{array}{l}\text { Frequency } \\
\text { Low High }\end{array}$ & $\begin{array}{l}\text { Scan } \\
\text { Score }\end{array}$ \\
\hline
\end{tabular}

61. - I don't like to keep the same chil-

$2 \quad 21 \quad 2.86$ dren too long.

95. + Babysitting money provides some "extras" for my family.

85. + Babysitting gives me my own spending money.

64. + Once I take a child, I'll keep him as $\quad 8 \quad 15 \quad 2.34$ long as I'm asked to.

44. + I have never asked for a child's re- $\quad 9 \quad 14 \quad 2.21$ moval.

77. + There is a big demand for babysitters $11 \quad 12 \quad 2.13$ in my neighborhood.

98. - I do babysitting even though I don't $\quad \begin{array}{llll}12 & 11 & 2.08\end{array}$ especially need the money.

88. + I try to keep at least a few children $11 \quad 12 \quad 2.04$ all the time.

36. + I can get along with any child.

$11 \quad 12 \quad 2.00$

81. + I would like to take care of more

$11 \quad 12 \quad 1.86$ children than I have.

83. - I can afford to be choosy about whom I sit for, because sitters are hard to

$13 \quad 10 \quad 1.82$ find.

43. - I try to have children who will stay a long time.

94. - I would refuse to babysit for some people.

$\begin{array}{lll}15 & 8 & 1.78\end{array}$

$17 \quad 6 \quad 1.43$

42. - I am not particular about the race of children I care for.

$19 \quad 4 \quad 1.21$ 
TABLE XXV (continued)

\begin{tabular}{|c|c|c|c|c|}
\hline \multirow{2}{*}{ Item } & & \multicolumn{2}{|c|}{ Frequency } & \multirow{2}{*}{$\begin{array}{l}\text { Mean } \\
\text { Score }\end{array}$} \\
\hline & & Low & High & \\
\hline $100 .+$ & $\begin{array}{l}\text { + I usually have a waiting list of } \\
\text { mothers who want me to keep their } \\
\text { children. }\end{array}$ & 19 & 4 & 1.21 \\
\hline $37 .+$ & $\begin{array}{l}\text { There are a lot of women in my } \\
\text { neighborhood who take care of chil- } \\
\text { dren. }\end{array}$ & 18 & 5 & 1.17 \\
\hline 79. + & $\begin{array}{l}+ \text { I could not take care of children of } \\
\text { a nother race in this neighborhood. }\end{array}$ & 19 & 4 & 1.13 \\
\hline 84. + & $\begin{array}{l}+ \text { I do babysitting because I don't have } \\
\text { any other choice. }\end{array}$ & 20 & 3 & 1.08 \\
\hline 75. + & $\begin{array}{l}+ \text { If I didn't do babysitting, I don't } \\
\text { know what I'd do to make money. }\end{array}$ & 20 & 3 & 1.04 \\
\hline 35. + & $\begin{array}{l}\text { + If I want to do babysitting, I have } \\
\text { to take what I can get. }\end{array}$ & 21 & 2 & .83 \\
\hline
\end{tabular}

24 items; $N=23$ sitters

Coefficient of reliability (odd-even): $r=.69$

(corrected for length of test)

TABLE XXVI

SOURCES OF ROLE DEPENDENCE FOR SITTERS

\begin{tabular}{|c|c|c|c|c|}
\hline \multirow{2}{*}{ Item } & & \multicolumn{2}{|c|}{ Frequency } & \multirow{2}{*}{$\begin{array}{l}\text { Mean } \\
\text { Score }\end{array}$} \\
\hline & & Agree & Disagree & \\
\hline 45. + & $\begin{array}{l}\text { I am not particular about the } \\
\text { sex of children I care for. }\end{array}$ & 22 & 1 & 3.04 \\
\hline 66. - & $\begin{array}{l}\text { I would not want to care for } \\
\text { a handicapped child. }\end{array}$ & 5 & 18 & 2.73 \\
\hline 49. + & $\begin{array}{l}\text { I am not particular about the } \\
\text { ages of children I care for. }\end{array}$ & 15 & 8 & 2.39 \\
\hline
\end{tabular}


TABLE XXVI (continued)

\begin{tabular}{|c|c|c|c|c|}
\hline \multirow{2}{*}{ Item } & & \multicolumn{2}{|c|}{ Frequency } & \multirow{2}{*}{$\begin{array}{l}\text { Mean } \\
\text { Score }\end{array}$} \\
\hline & & Agree & Disagree & \\
\hline 76. & $\begin{array}{l}\text { I would not keep a child who } \\
\text { doesn't get along here. }\end{array}$ & 20 & 3 & 1.13 \\
\hline 38. & $\begin{array}{l}\text { - I won't keep caring for a child } \\
\text { if the mother isn't reliable } \\
\text { about paying. }\end{array}$ & 20 & 3 & 1.08 \\
\hline 57. & $\begin{array}{l}\text { - I won't care for a child if I } \\
\text { don't get along with the mother. }\end{array}$ & 20 & 3 & .1 .04 \\
\hline 65. & $\begin{array}{l}\text { - Working mothers have a hard } \\
\text { time getting good sitters. }\end{array}$ & 21 & 2 & .69 \\
\hline
\end{tabular}

Sitters were not particular about the sex or age of the children they cared for. They also tended to disagree that they would not care for a handicapped child.

It was important to the sitters that the child get along in the day care arrangement and that the mother and the sitter get along. It was also important that the mother was reliable about paying. Sitters also felt that working mothers had a hard time getting good sitters.

The 19 best discriminating items on the sitter's role satisfaction scale are shown in Table.XXVII. 
TABLE XXVII

SUMMATED-RA TING SCALE OF SITTERS' SA TISFACTION (Sitters' RS)

\begin{tabular}{|c|c|c|c|c|}
\hline \multirow{2}{*}{ Itém } & & \multicolumn{2}{|c|}{ Frequency } & \multirow{2}{*}{$\begin{array}{l}\text { Mean } \\
\text { Score }\end{array}$} \\
\hline & & High & Low & \\
\hline 48 & $\begin{array}{l}+ \text { I get a lot of satisfaction out of see- } \\
\text { ing children grow up. }\end{array}$ & 23 & 0 & 3.26 \\
\hline 52. + & $\begin{array}{l}+ \text { Child care is one of the most im- } \\
\text { portant jobs a woman can have. }\end{array}$ & 22 & 1 & 3.17 \\
\hline 82. + & + I like helping out mothers who work. & 23 & 0 & 3.13 \\
\hline $39 .+$ & $\begin{array}{l}+ \text { Children learn a lot from staying in } \\
\text { someone else's home during the day. }\end{array}$ & 22 & 1 & 3.13 \\
\hline 70. + & $\begin{array}{l}\text { My own children think it's fun to } \\
\text { have other children around. }\end{array}$ & 21 & 2 & 3.13 \\
\hline 46. + & $\begin{array}{l}+ \text { I like helping out children of work- } \\
\text { ing mothers. }\end{array}$ & 22 & 1 & 3.08 \\
\hline 74. + & $\begin{array}{l}+ \text { I get a lot of satisfaction out of } \\
\text { taking care of children. }\end{array}$ & 20 & 3 & 3.00 \\
\hline 47. & $\begin{array}{l}\text { My husband (or family) doesn't } \\
\text { approve of my doing babysitting. }\end{array}$ & 19 & 4 & 2.86 \\
\hline 67. + & $\begin{array}{l}+ \text { Being a baby sitter makes me feel } \\
\text { I'm doing something worthwhile. }\end{array}$ & 20 & 3 & 2.82 \\
\hline 96. + & $\begin{array}{l}\text { I would feel lost if I didn't have } \\
\text { any children around. }\end{array}$ & 18 & 5 & 2.78 \\
\hline 86. - & $\begin{array}{l}\text { My own children pick up bad habits } \\
\text { from the day care children. }\end{array}$ & 18 & 5 & 2.73 \\
\hline 99. + & $\begin{array}{l}\text { One of the nice things about doing } \\
\text { babysitting is getting to know the } \\
\text { mothers. }\end{array}$ & 18 & 5 & 2.73 \\
\hline 50. - & $\begin{array}{l}\text { Sometimes mothers say they will } \\
\text { bring their children and they don't } \\
\text { show up. }\end{array}$ & 12 & 11 & 2.17 \\
\hline 40. - & - Mothers tend to impose on sitters. & 11 & 12 & 2.04 \\
\hline
\end{tabular}


TABLE XXVII (continued)

\begin{tabular}{|c|c|c|c|c|}
\hline \multirow{2}{*}{ Item } & & \multicolumn{2}{|c|}{ Frequency } & \multirow{2}{*}{$\begin{array}{l}\text { Mean } \\
\text { Score }\end{array}$} \\
\hline & & High & Low & \\
\hline 55. + & $\begin{array}{l}\text { I am appreciated more at home } \\
\text { because I give child care. }\end{array}$ & 11 & 12 & 2.04 \\
\hline $68 .-$ & $\begin{array}{l}\text { Mothers sometimes aren't very } \\
\text { reliable about paying me. }\end{array}$ & 11 & 12 & 1.86 \\
\hline 41. + & $\begin{array}{l}\text { I like comparing my children with } \\
\text { other people's children. }\end{array}$ & 9 & 14 & 1.82 \\
\hline 51. + & $\begin{array}{l}\text { My day care children appreciate me } \\
\text { more than my own children do. }\end{array}$ & 5 & 18 & 1.60 \\
\hline 63. + & $\begin{array}{l}\text { It's easier to take care of other } \\
\text { people's children than it is your } \\
\text { own. }\end{array}$ & 7 & 16 & 1.60 \\
\hline
\end{tabular}

19 items; $N=23$

Coefficient of reliability (odd-even): $r=.72$

(corrected for length of test)

Eight of the original role satisfaction items were non-

discriminatory. These items are listed in Table XXVIII.

Sitters felt a mother should not work unless it was absolutely necessary. Giving day care is the sitter's preferred choice. Her husband and/or family prefers this role for her also.

Sitters felt others knew they did babysitting. They believed the neighbors approved and that no one was critical of them for doing babysitting. 
TABLE XXVIII

SOURCES OF ROLE SATISFACTION FOR SITTERS

\begin{tabular}{|c|c|c|c|c|}
\hline \multirow{2}{*}{ Item } & & \multicolumn{2}{|c|}{ Frequency } & \multirow{2}{*}{$\begin{array}{l}\text { Mean } \\
\text { Score }\end{array}$} \\
\hline & & Agree & Disagree & \\
\hline 69. - & $\begin{array}{l}\text { - I don't like to admit to people } \\
\text { that I do babysitting. }\end{array}$ & 2 & 21 & 3.17 \\
\hline 97. & $\begin{array}{l}\text { - My husband (or family) would } \\
\text { prefer that I went out to work } \\
\text { ins tead of babysitting. }\end{array}$ & 1 & 22 & 3.13 \\
\hline $58 .+$ & $\begin{array}{l}+ \text { I would rather do babysitting } \\
\text { than go out to work. }\end{array}$ & 18 & 5 & 2.73 \\
\hline 60. - & $\begin{array}{l}\text { - I feel criticized for doing } \\
\text { babysitting. }\end{array}$ & 4 & 19 & 2.69 \\
\hline 72. + & $\begin{array}{l}+ \text { My neighbors approve of } \mathrm{my} \\
\text { doing babysitting. }\end{array}$ & 17 & 6 & 2.56 \\
\hline 71. & $\begin{array}{l}\text { - I'd rather have some other } \\
\text { job than babysitting. }\end{array}$ & 8 & 15 & 2.3 .9 \\
\hline 93. + & $\begin{array}{l}+ \text { I'm all in favor of mothers' } \\
\text { working. }\end{array}$ & 5 & 18 & 1.21 \\
\hline 54. & $\begin{array}{l}\text { - Mothers shouldn't work unless } \\
\text { they absolutely have to. }\end{array}$ & 21 & 2 & .69 \\
\hline
\end{tabular}

\section{$\underline{\text { Findings }}$}

The study did not find support for the hypothesis that contintuity of the family day care arrangement is dependent in part on the sitter's satisfaction with her role as a sitter, on her perceived dependence on performance of her sitting role, and on her satisfaction with the particular relationships and circumstances of the last arrangement. 
As reported in Chapter III, the relationship between each of the scales and the number of weeks' duration of the arrangement was tes ted by Spearman Rank Order Correlation. These correlations were not statistically significantly different from zero at the five percent level and did not result in rejection of the null hypothesis.

Since the measures were reliable, the lack of as sociation cannot be attributed to low reliability, and it was necessary to conclude that the value of the arrangements to the sitters alone, by itself and as measured, did not account for the variation in duration of arrangements for the sitters in the sample.

For the sitters, however, a scalar relationship was found between whether they reported getting what they were looking for in an arrangement and satisfaction with the particular arrangement (LAS):

$\begin{array}{lcc} & \text { Get } & \text { Not Get } * \\ \text { High LAS } & 11 & 0 \\ \text { Low LAS } & 7 & 5\end{array}$

With a zero cell, the distribution shows a scalar pattern, rather than a pattern of association or chance expectancy. It can

* Responses to Item 14 in the interview schedule served to dichotomize sitters in terms of "getting" and "not getting." A respondent was classified as "not get" if her last arrangement lacked one or more of the characteristics which she had indicated as being important to her, or if she only got "partially" what she was looking for, in two or more such characteristics. 
be seen that all of those sitters who said during the interview that they did not find what they were looking for in an arrangement scored low on satisfaction (LAS), while all of those with high satisfaction did report getting what they were looking for. However, "getting" was not necessarily accompanied by high satisfaction. These results are not surprising. Indeed, they lend confidence in the validity of the data, since having one's expectations met was conceived as fundamental to satisfaction.

An additional finding, however, was that, as with the mothers (see Chapter IV), the sitters' role dependence scores showed an inverse scalar pattern in relation to getting what they were looking for in an arrangement:

Get Not Get

High RD 7

Low RD $11 \quad 0$

$$
N=23
$$

All sitters who reported not getting what they were looking for in an arrangement scored high on role dependence; that is, they tended to see themselves as having little choice about working and as having to take what they could get in an arrangement. On the other hand, a sense of freedom of choice (low dependence) characterized only those sitters who reported getting what they were looking for.

This latter scalar pattern was not anticipated and is especially interesting. The role dependence scale was designed to measure 
the value of the arrangement arising from the degree to which it was seen as the only available alternative. It was a low degree of role dependence only, however, that invariably was associated with a prime condition of satisfaction, that of getting what the sitter was looking for in an arrangement.

The relationship between these variables is further clarified by Guttman scale analys is of the sitters' dichotomized responses to the three variables:

A. Getting vs. not getting what the sitter was looking for in an arrangement;

B. High vs. low satisfaction with the particular arrangement (LAS), and

C. Role freedom vs. role dependence (reversing the signs for the role dependence scale scores to conform to the way in which freedom of choice operated).

The scale had a Coefficient of Reproducibility of .96 and met minimum standards for scalograms except for the few number of items involved. This scale gave us four types of sitters, in which all but three of the 23 sitters were perfect scale types, exceeding the expected frequency of scale types for the sample of responses by $\mathrm{p}=.02$

Thus, the scale presents an ordered picture of typical responses of the sample of sitters. The scale also presents a newly 
TABLE XXIX

SITTERS' SATISFACTION AND ROLE FREEDOM:

A GUTTMAN SCALE

\begin{tabular}{|c|c|c|c|c|c|c|c|}
\hline Types & $\begin{array}{l}\mathrm{C} \\
\mathrm{RF}\end{array}$ & $\begin{array}{c}\text { B } \\
\text { LAS }\end{array}$ & $\begin{array}{c}\text { A } \\
\text { Get }\end{array}$ & $\begin{array}{c}f \\
\text { Scale } \\
\text { Types }\end{array}$ & & $\begin{array}{c}f \\
\text { Non- } \\
\text { Scale } \\
\text { Types }\end{array}$ & $\begin{array}{c}\text { No, } \\
\text { Errors }\end{array}$ \\
\hline 4 & + & + & + & 8 & & 3 & 3 \\
\hline 3 & - & + & + & 3 & & & \\
\hline 2 & - & - & + & 4 & & & \\
\hline \multirow[t]{2}{*}{1} & - & - & - & 5 & & - & - \\
\hline & & & Total & 20 & + & $3=23$ & 3 \\
\hline+ & 11 & 11 & 18 & & & & \\
\hline- & 12 & 12 & 5 & & & & \\
\hline
\end{tabular}

Reproducibility $=.96$

Minimum Marginal Rep. $=.58$

Observed frequency of Scale Types $=20 ; \mathrm{z}=2.048 ; \mathrm{p}=.02$

Expected frequency of Scale Types $=14.8$

constructed independent variable which orders the components and conditions of satisfaction among the sitters. The scalogram reveals that a sitter who perceived herself as having a high degree of freedom of choice (role freedom), also was satisfied with her arrangement (LAS), and reported getting what she was looking for in an arrangement. A sitter who failed to get what she was looking for, scored low also on LAS and role freedom.

It is perhaps a significant finding that this Guttman scale for 
the sitter's paralleled the Guttman scale for the mothers, which is described in the preceding chapter. Both scalograms linked high satisfaction and getting what the respondents were looking for with role freedom, and revealed a parallel ordering of the independent variables for different sets of respondents; that is for both the users and givers of day care.

This newly constructed independent variable for the sitters was found to have only a chance association with the dependent variable--duration of the arrangement. 


\section{CHAPTER VI \\ SUMMARY AND IMPLICATIONS}

The findings of this project are concerned with the sources of costs and rewards in social exchange as applied to the family day care system. Most of these findings have been analyzed in the preceding chapters. In this chapter an attempt will be made to interpret these findings in the light of ideas that were suggested in the process of gathering and analyzing the data.

In looking back over the study, it appears that the original hypothesis* was based on a questionable assumption, at least for the sample studied, and may have been characterized by traditional middle-class thinking and values. The hypothes is assumed that a high degree of dependence (on a child care arrangement) would lead to continuity; in other words, that a mother who is highly dependent on such an arrangement would "work" at keeping the arrangement . going.

The formulation of this hypothesis was based on the planned selection of two distinct samples--one from the Day Care Exchange Project and the other from the Public Welfare Commission--which, it was assumed, would cut across socio-economic class lines. In

* The original hypothesis stated that discontinuity is a function of the independent variables of satisfaction and dependence. 
actual fact, however, the high sample los from the Day Care Exchange Project left a skewed sample population--one that drew essentially from the sub-culture of the poverty level. Twenty-one of the mothers in the study had family incomes under $\$ 5,000$ annual$1 y ; 14$ of these incomes were under $\$ 3,000$. In the sitter sample, 15 of the 23 incomes were from the under $-\$ 5,000$ bracket; 7 had family incomes under $\$ 3,000$. One possible conclusion might be, therefore, that the mothers and sitters studied drew their attitudes and behavior from the culture of poverty which has been described as "pragmatic, materialistic [and] present-oriented" (Meyers and Roberts as quoted by. Chilman, 1966). The following quotation describes the situation of many of the respondents extremely well:

When getting and holding a job and buying food are paramount necessities of the moment, many middle-class values, such as consideration of the subtleties of human relationships, are necessarily pushed to the background. (Chilman, 1966, p. 6)

Since 14 of the mothers and 12 of the sitters were classified as "high-dependent"--i.e., under considerable pressure to work--as well as from the lower-income brackets, it might be assumed that they, would indeed formulate "pragmatic and present-oriented" child care arrangements. Analysis showed that mothers and sitters who were most affected by the need to work were least satisfied with their arrangements. Perhaps this lack of satisfaction is directly 
related to the costs and rewards within the relationships. If these respondents could not afford the "subtleties of human relationships" as is implied by their dependency and their low socio-economic status, response items geared to tapping these valuations would receive unexpected results. Furthermore, a "pragmatic and present-oriented" attitude would doom many of these relationships to failure, for, rather than "working at" the relationship--as had been assumed in the hypothesis--the participants would economize on the "human relationship" item as a cost they could not afford. Even those respondents who felt they could not afford the costs of meeting their emotional needs were nevertheless unable to ignore them. Thus when the rewards did not balance the costs, the relationship terminated despite an expressed pragmatic need to sustain it.

On the other hand, it should be pointed out that the measure of dependence differentiated both a high dependent and a low dependent group within the sample. Thus, a predominantly poverty level sample of mothers and sitters was not universally "high dependent." Furthermore, it is not known whether the dependence variable would operate in the same way or differently. in other groups.

Pressure on the mothers is indicated not only by their scale scores and schedule responses but also by their casual remarks to the interviewers. Among the mothers classified as "high-dependent" 
many commented that they were not particularly interested in their work or their training courses but felt that they could not give them up because of the criticism they would receive from the welfare agency, from the community or from themselves. At the same time they expressed concern about the effects of their working on their children and mentioned difficulties of obtaining adequate child care arrangements. Some evidence of perceived dependence on the welfare department's authority was suggested by the mothers' frequent statements that the amounts they were paying for child care were fixed by the welfare department when, in fact, this policy is quite flexible and leaves the mother considerable freedom to negotiate. The power of the welfare department nevertheless is perceived as so great that a mere suggestion from one of its representatives-("The going rate in the community is $X$ number of dollars")--is taken as an absolute and final measure.

Feelings of exploitation and powerlessness are reported to be indigenous to the poverty population (Seeman, 1957; Levinson, 1964; Ferman, 1965) and may account for the mothers' apparent inability to resist pressure, not only from the community and the welfare agency, but from the sitters as well. As described in Chapter IV, 19 of the mothers saw themselves as having little power in their relationships with the sitters and as needing to accommodate themselves 
to the sitters! wishes.* This passive kind of adaptation seems to be the only kind of maintenance behavior with which the mothers are familiar. Their selection procedures also may be interpreted as bearing the stamp of the culture of poverty; i. e., selection of a sitter by the "high-dependent" mothers suggested an impulsive, short-sighted orientation with an emphasis on convenience and the kind of limited security provided by selecting a friend or acquaintance. It might be argued that a middle class parent, on the other hand, would tend to emphasize good child-rearing practices and potential stability of an arrangement.

These conjectures about the sample indicate the need for further study; however, if there is validity to the findings and the discussion, some implications for practice and further research may be predicated on this study.

\section{Implications for Practice}

(1) Although this study was confined to family day care arrangements, the mothers were asked their preferences in regard to various types of child care. Several scale items tapped valuations regarding alternate child care arrangements. Despite the emphasis in recent publicity releases and in the professional

* As pointed out, these were the "high-dependent" mothers. 
literature regarding day care centers, the mothers in this study did not show a marked preference for this type of care. Table XXX shows the mothers' preferences for family day care in relation to three other types of day care; i.e., sitter in the home, relative or family member as child-caring person, or day care center.

\section{TABLE XXX}

MOTHER'S DAY CARE PREFERENCES: A GUTTMAN SCALE

\begin{tabular}{|c|c|c|c|c|c|c|c|}
\hline Тур & & $\begin{array}{l}\text { Item \#75 } \\
\text { Prefer } \\
\text { fdc to }\end{array}$ & $\begin{array}{l}\text { Item } \# \mathbf{5 4} \\
\text { Prefer fdc } \\
\text { to relative } \\
\text { or member }\end{array}$ & $\begin{array}{c}\text { Item \#49 } \\
\text { Prefer } \\
\text { fdc to }\end{array}$ & $\begin{array}{c}\mathrm{f} \\
\text { Scale }\end{array}$ & & $\begin{array}{c}f \\
\text { Non- } \\
\text { Scale }\end{array}$ \\
\hline & & $\mathrm{C}$ & B & A & & & \\
\hline $\mathrm{High}$ & 4 & + & + & + & 4 & & 2 \\
\hline & 3 & - & + & + & 8 & & 2 \\
\hline & 2 & - & - & + & 3 & & \\
\hline Low & 1 & - & - & - & 7 & & $\underline{1}$ \\
\hline & & & & Total & 22 & + & $5=27$ \\
\hline & + & 7 & 16 & 15 & & & \\
\hline & - & 20 & 11 & 12 & & & \\
\hline
\end{tabular}

Reproducibility $=.94$

Minimum Rep. $=.63$

Observed frequency of scale types: 22

Expected frequency of scale types: $17 ; z=1.78 ; p=.04$

Description of scale types:

Type 4 prefers family day care to other alternatives.

Type 3 prefers sitter at home to family day care, but prefers family day care to relatives and center care.

Type 2 prefers both sitter at home and relatives to family day care, but prefers family day care to day care center.

Type 1 prefers day care center and all other alternatives to family day care. 
If these findings regarding the stated day care preferences among family day care users validly represent important attitudes of these mothers, then social work intervention also should be directed at assisting mothers to find more in-the-home baby sitters, or at improving the quality of interaction in family day care arrangements such as is attempted by the Day Care Exchange Project. Both of these areas need further exploration and expansion.

(2) The study suggests that the formation of family day care arrangements may lie largely. in the hands of the mothers, or users of family day care. These mothers also see themselves as responsible for maintaining their day care relationships. Perhaps another function of social work intervention includes responsibility for assisting the mothers with some guidance in the selection and maintenance of such arrangements. Such guidance should include attempts to increase the mothers' and sitters' understanding of the sources of reciprocal satisfaction that contribute to the stability of day care arrangements.

Establishment of an "emergency" day care service, under social work auspices, also might temper the high rate of discontinuity arising out of poorly considered arrangements formed under. conditions of pressure.* Such a service would provide a "breathing

* We are indebted to Gordon Hearn, Ph. D., Dean of the Portland State School of Social Work, for this idea. 
spell" for the "high-dependent" mothers while involving them in sound casework planning for long-range day care.

(3) The low-income mother is severely restricted in "shopping" for an adequate day care arrangement because of the limited amount she is able to pay and because of the lack of adequate facilities within her shopping range. Solong as the community tolerates situations such as that of the young mother who, after undergoing a welfare department training program for secretary and obtaining a full-time job, still needed a supplemental welfare check to meet her family's minimum requirements, the prospect for breaking through this constricting range is dim.

Similarly, it has been shown that sitters who are willing to work for the wages these mothers can pay often do not meet the mothers:' expressed preferences. Thus, indications point to social action in relation to higher wage scales for both mothers and sitters. It is possible that at least partial subsidies to the sitters are necessary to achieve a workable ratio between mother-sitter wages. Some recognition has been given to the need for such a program by the so-called Daycare bill signed by President Johns on in 1962 . This bill has stringent limitations, however, which markedly curb its effectiveness. First, it covers only day care facilities for children under six years of age, excluding the older child and the handicapped child (regardless of age) who need day care facilities. 
Secondly, the appropriation amounts to $\$ 2.50$ per year per child for the approximately 4,000,000 children under six of working mothers! Such a limited program can hardly be seen as an adequate incentive for communities wishing to establish day care facilities. Social workers need to make their elected representatives aware of the real needs for day care within their communities and take the initiative in putting what funds are available to the best possible use.

\section{Implications for Further Research}

(1) Because of the high sample loss from the Day Care Exchange Project's sample of mothers, the major portion of the mother sample was derived from the welfare department and may represent a sub-cultural pattern. As has been stated, the original hypothesis did not take into account the full range of values that might be indigenous to such a group. The research instruments may therefore have lacked scope to tap the entire range of satisfaction in this sample.

Perhaps further research could develop instruments more sensitive to the sub-cultural patterns and measure the distinctions between samples more effectively.

(2) The research instruments which served well for the mothers did not serve equally well for the sitters. Sitters indicated their dissatisfaction with the high rate of discontinuity of day 
care arrangements but the research instruments did not probe the sitters' sources of satisfaction so effectively as the mothers. There is some indication that the sitters did perceive termination (when initiatived by the mothers) as a form of personal rejection (Collins, 1966) but this point could bear further research.

(3) Data indicate considerable confusion about reasons for and procedures of termination. Except for the respondents involved in arrangements which had a pre-determined termination date (e.g., the end of a training program), none seemed clear about the manner in which termination should be arranged. Indeed, inspection of the matched pairs of mothers and sitters indicates that there is not even total agreement on who initiated termination! No formal "notice" was given and most of the terminations occurred abruptly, frequently leaving the mother in need of making another (possibly hasty) arrangement.

(4) The attempt to measure perceived satisfaction and dependence holds some promise as an approach, and findings of the present study suggest that it may be possible to predict continuity of family day care arrangements from measures of the perceived value of the arrangement.

(5) Comparison of the high dependent and low dependent working mothers with emphasis on their modes of adaptations, their social class, subcultural backgrounds and the pressures of their 
life circumstances, might well form a basis for clearer understanding of the values and needs of these mothers which in turn affect their child care arrangements .

(6) Analysis of the interaction between mothers and sitters in the 20 matched pairs studied, provides some provocative suggestions for further research.

(a) As shown in previous chapters, the LAS (satisfaction with the last arrangement) scores for the mothers or sitters alone were not significantly related to duration. However, when the LAS scores for each pair of mothers and sitters were summed, the total or joint satisfaction score for each pair correlated with duration of the arrangement (Rho $=.49 ; \mathrm{p}<.05)$. As a check on this finding the relationship between LAS and duration was examined separately for the 20 mothers and 20 sitters. For these mothers duration was found to be associated with LAS (Rho $=.55 ; \mathrm{p}<.01$ ) * but no such association was found for the sitters (Rho $=.18$ ). It would thus appear that for this sample the relationship between joint LAS and duration may be largely attributed to the mothers' satisfaction with the arrangement.

* This correlation was higher than the correlation for the total sample of mothers, as reported in Chapter III. The sample loss of mothers for whom paired data was unavailable contained six cases that ran extremely counter to hypothesis. 
(b) Guttman scale analys is for the 20 paired arrangements supports this finding regarding the relative importance of the mothers' satisfaction for the continuity of the arrangement. The Guttman scale of paired data (Table XXXI) parallels the scalograms for the sample of the mothers and of the sitters. Mutual role freedom (RF), mutual satisfaction with the last arrangement (LAS) and getting what they were looking for scaled in the same manner for the matched pairs.

TABLE XXXI

MOTHERS' AND SITTERS' PAIRED SATISFACTION AND ROLE FREEDOM: A GUTTMAN SCALE

\begin{tabular}{|c|c|c|c|c|c|c|c|c|}
\hline Types & $\begin{array}{c}\mathrm{D} \\
\text { Mutual } \\
\mathrm{RF}\end{array}$ & $\begin{array}{c}\text { C } \\
\text { Mutual } \\
\text { LAS }\end{array}$ & $\begin{array}{c}\text { B } \\
\text { Mother } \\
\text { Get }\end{array}$ & $\begin{array}{c}\text { A } \\
\text { Sitter } \\
\text { Get }\end{array}$ & $\begin{array}{c}f \\
\text { Scale } \\
\text { Types }\end{array}$ & & $\begin{array}{c}\mathrm{f} \\
\text { Non- } \\
\text { Scale E } \\
\text { Types }\end{array}$ & $\begin{array}{l}\text { No. } \\
\text { Errors }\end{array}$ \\
\hline 5 & + & + & + & + & 4 & & & \\
\hline 4 & - & + & + & + & 3 & & 1 & 1 \\
\hline 3 & - & - & + & + & 5 & & & \\
\hline 2 & - & - & - & + & 3 & & 1 & 1 \\
\hline \multirow[t]{2}{*}{1} & - & - & - & - & 2 & & 1 & $\underline{1}$ \\
\hline & & & & Total & 17 & + & $3=20$ & 3 \\
\hline+ & 5 & 8 & 13 & 17 & & & & \\
\hline- & 15 & 12 & 7 & 3 & & & & \\
\hline
\end{tabular}

Reproducibility $=.96$

Minimum Marginal Rep. $=.71$

Observed Frequency of Scale Types $=17$

Expected Frequency of Scale Types $=12.5 ; \mathrm{z}=1.826 ; \mathrm{p}=.02$ 
Furthermore, the types of arrangements described in this scalogram of paired data correlates with the duration of the arrangement in the same direction and manner as was found for the mothers sample. (See Table XXXII.)

TABLE XXXII

DURA TION OF ARRANGEMENT BY SCALE TYPE ON THE SCALOGRAM OF MOTHERS' AND SITTERS' PAIRED SATISFACTION AND ROLE FREEDOM

\begin{tabular}{lllllll}
\hline & Types & & & & \\
Duration & 5 & 4 & 3 & 2 & 1 & \\
\hline Long * & 3 & 0 & 2 & 0 & 0 & 5 \\
Medium *** & 1 & 3 & 1 & 2 & 1 & 8 \\
Short $* * * *$ & 0 & 1 & 2 & 2 & 2 & 7 \\
\end{tabular}

Rho $=.51 ; \mathrm{p}<.05$ (corrected for ties)

* 12 weeks or more

*** 5 - 10 weeks

$* * * * 4$ weeks or less

\section{Conclusion}

This research project was a pilot study in social exchange in family day care arrangements. Its findings suggested that satisfaction with an arrangement must be present for the arrangement to endure. One of the conditions of satisfaction appears to be having one's expectations met regarding the arrangement. Several avenues 
of research possibilities remain unexplored. The project, therefore, provides opportunities for elaboration from a number of perspectives and a variety of interest fields. This project only touched on a study of interaction of matched pairs of mothers and sitters, for example, and this area could be elaborated further. Preferences for various types of day care and their implications for social work intervention also bear further study. Because the number of working mothers and the need for day care facilities appears to be on a steady increase, research which would contribute to an improved understanding of the attitudes, behavior and needs of this population could make a major contribution to a more satisfactory and productive way of life for the families involved and the communities in which they live. 


\section{BIBLIOGRAPHY}

1. Abstracts of research and demonstration projects in social welfare and related fields. U.S.H.E.W., Bureau of Family Services. U. S. Government Printing Office 0-797-816, $1966,249 \mathrm{p}$.

2. Bagdikian, B. H. Who is sabotaging day care for our children? Ladies Home Journal 83:86. Nov. 1966.

3. Beer, Ethel. Need for day care. Social Science 37:236. Oct. 1962 .

4. Benjamin, Lois and Arthur Henley. What every mother owes to her child and herself. Ladies Home Journal 83:69. June 1966.

5. Benjamin, Lois. How to be a working mother without really crying. Ladies Home Journal 83:21. May 1966.

6. Blau, Peter M. A theory of social integration. American Journal of Sociology 65:545-556. May 1960.

7. Exchange and power in social life. New York, Wiley, 1964. $352 \mathrm{p}$.

8. Blood, Robert O., Jr. and Robert L. Hamblin. The effects of the wife's employment on the family power structure. In: The Family (ed.) Norman W. Bell and Ezra F. Vogel, The Free Press of Glencoe, 1960. p. 137-142.

9. Blood, R. O., Jr. Long-range causes and consequences of the employment of married women. Journal of Marriage and Family 27:43-7. February 1965.

10. Bowlby, J. Separation anxiety. International Journal of Psychoanalysis 41:89-113. March-June 1960.

11. Briar, Scott. Welfare from below: recipients' views of the public welfare systern. California Law Review 54:370-385. May 1966.

12. Brittain, Clay and Seth Low. Child care arrangements of nation's working mothers. Women's Bureau of Labor Department, $1965.14 \mathrm{p}$. 
13. Burke, Lee and Rachel M. Inselberg. When a mother works. Today's Health, Nov. 1966. p. 3-5.

14. Caldwell, Bettye M., Ph. D. and Julius B. Richmond, M. D. Foster day care. Journal of Marriage and the Family 26: 481 -488. November 1964.

15. Captainesses of industry (too few women in responsible jobs.) Ed. i1. Economist 212:822-3. Ag. 26 (1964)

16. Cauman, Judith. Foster day care and group day care: two essentials of a basic child welfare service. Child Welfare. Vol. 40, No. 8. 1962. p. 20-23.

17. Chilman, Catherine S., Ph. D. Growing up poor. U. S. Dept. of Health, Education \& Welfare, Welfare Administration, Division of Research, Washington, D. C., 20201, \#13. May 1966.

18. Child care arrangements of the nation's working mothers: a preliminary report. U.S. Dept. of Health, Education and Welfare, Children's Bureau and U.S. Department of Labor, Women's Bureau. 1965. 14 p.

19. Close, Kathryn. Day care as a service for all who need it. Children 12:157-160. July-August 1965.

20. Collins, Alice H. Some efforts to improve family day care. Children 13:135-140. July-August 1966.

21. The day care exchange project. D-135 (C1) Progress Report. Mimeo July 1, $1965.11 \mathrm{p}$.

22. The day care exchange project. Portland, Oregon Community Council. Mimeo December, 1966. 111 p.

23. Cook, Judith. Why married women don't work. New Statesman 69:600. April 16, 1965.

24. Davis, A. E. Hospital topics. Volume 43:45-51. December, 1965.

25. Hospital topics. Volume 44:49-57.

January, 1966. 
26. Day care services. Children's Bureau, \#51. 1960. 62 p.

27. Day care for other people's children in your home. Children's Bureau, U. S. Government Printing Office, \#411. 1964. 17 p.

28. Day care for your child in a family home. Children's Bureau, U. S. Government Printing Office, \#412. 1964.14 p.

29. Day care of children. Bureau of Educational Research and Development, U. S. Government Printing Office, \#460. 1966.

30. Determining fees for day care services. Children's Bureau, U. S. Government Printing Office. 1963 or $1964.14 \mathrm{p}$.

31. Dumpson, James. Place of day care in meeting children's needs. Child Welfare 43:182-186. April. 1964.

32. Edwards, Allen L. Techniques of attitude scale construction. New York, Appleton-Century-Croft, 1957. 256 p.

33. Emlen, Arthur C., Alice H. Collins, Eunice L. Watson. Field study of the neighborhood family day care system: A research proposal. Mimeo July 1, 1966. 33 p.

34. Fanning, W. W. Child-care nursery: One hospital's solution to nursing shortage. Hospital Topics 43:51-2. December 1965.

35. Fees for day care services. Children's Bureau, U. S. Government Printing Office, 64-32, 1963. 20 p.

36. Ferman, Louis A., Joyce L. Kornbluh and Alan Haber (eds.) Poverty in America: a book of readings. University of Michigan Press, Ann Arbor, 1965. 532 p.

37. Fleming, Thomas J. Sex and civil rights. Parade Magazine, 4-6, March 19, 1967.

38. Foley, Frank A. Family day care for children. Children 13:141-144. July - August, 1966.

39. Friedan, Betty. The feminine mystique. New York, Dell Publishing Company, 1963. $384 \mathrm{p}$.

40. Gibson, Gwen. One woman can make the difference: A blueprint for day care action. Ladies Home Journal 83:62. September 1966. 
41. Goffman, Erving. Stigma: Notes on the management of spoiled identity. Englewood Cliffs, New Jersey, Prentice Hall, 1964 . $147 \mathrm{p}$.

42. Goode, W. J. and P. Hatt. Methods in social research. New York, McGraw Hill, 1952. 386 p.

43. Gouldner, Alvin W. The norm of reciprocity: A preliminary statement. American Sociological Review 25. April, 1960. p. $161-178$.

44. Guggenheimer, Mrs. Randolph. Public welfare's role in day care for children. Children, June 1962. p. 109-113.

45. Guides to state welfare agencies for development of day care services. Children's Bureau, June 1963, FS 14.108, d/33/2.

46. Guttman, Louis. The basis of scalogram analysis. In: The American Soldier: Studies in Social Psychology in World War II, Volume 4, Measurement and Prediction. Stauffer, Samuel et al. Princeton University Press, 1950. p. 60-90.

47. Handbook on Women Workers. U. S. Women's Bureau, \#290. 1965. $321 \mathrm{p}$.

48. Hansan, John E., ACSW and Kathryn M. A. Pemberton. Day care: A therapeutic milieu. Child Welfare 44:149-155. March 1965.

49. Harrison, E. Working woman: Barriers in employment. il Pub. Adm. R. 24:78-85. June 1964.

50. Hearn, Gordon. Group survival: The maintenance system. In: Theory of group developrnent, Chapter 16 (unpublished manuscript, 1964), $37 \mathrm{p}$.

51. Heinicke, Christoph M. and Ilse J. Westeheimer. Brief separations. New York, International Universities Press, 1965. $355 \mathrm{p}$.

52. Herzog, Elizabeth Children of working mothers. Children's Bureau, \#382, U.S. Government Printing Office, 1960, rev. 1964. $38 \mathrm{p}$. 
53. Day care services, form and substance. Children's Bureau,\#393. 1961. 53 p.

54. Hoffman, Gertrude. National conference of day care for children's services. Women's Bureau Labor Department, Bulletin \#281. 1962.

55. Homans, George C. Social behavior as exchange. The American Journal of Sociology 62:587-606. May 1958.

56. The human group. New York, HarcourtBrace, $1950.484 \mathrm{p}$.

57. Hutchinson, A. Galen Home--a day centre for the needs of physically handicapped subnormal children. Spastics Quarterly 13:39-46. June, 1964.

58. Kenistor, E. and K. K. American anachronism--the image of women who work. American Scholar 33:355-75. Summer 1964.

59. Kuh, Joyce. Would this day care plan work for you? Ladies Home Journal 83:120. October, 1966.

60. Larrea, C. Burga. Legal protection of infant child of working mother. Pediatric Americas 2:654-658. Nov. 15, 1944.

61. Lajewski, Henry J. Child care arrangements of full-time working mothers. Children's Bureau, \#378. U.S. Government Printing Office, Washington, D. C. $1959.14 \mathrm{p}$.

62. Levinson, Daniel J. and Eugene B. Gallagher. Patienthood in the mental hospital: An analysis of role, personality and social structure. Boston, Houghton-Mifflin, 1964. 265 p.

63. Levinson, Perry. Reciprocity and alienation in a social system. unpublished, 1964. Symposium on family management.

64. Low, Seth. Licensed day care facilities for children. Report of National Survey of Department of State Government Responsible for Licensing Day Care Facilities. 1962. HEW 62-79. 29 p.

65. Maas, Henry S. (ed.). Five fields of social service: Reviews of research. National Association of Social Workers, New York. January 1966. 208 p. 
66. Mabre, Alfred, Jr. Working wives. Wall Street Journal 162:1. October 30, 1963.

67. Maccoby, Eleanor E. Children and working mothers. Children 5:83-89. May-June 1958.

68. McGinnis, Robert. Scaling interview data. American Sociological Review 18:514-521. October 1953.

69. Merriam, Alice. Selected bibliography on day care services. Children's Bureau, 0-771-562. Washington, D.C., 1965. $94 \mathrm{p}$.

70. Miller, Ann. Care for children of working mothers. American Journal of Nursing 65:94-96. May 1965.

71. Mothers at work. A publication of the Metropolitan Life Insurance Company. August 1964. $16 \mathrm{p}$.

72. Nation's working mothers and need for day care. Address by Mary Dublia Keyserling, Director Women's Bureau, Department of Labor, NCDC Services, Washington, D. C. , 3-14-65. L13.13 K5219. U.S. Government Printing Office. 1965.

73. Nye, F. Ivan V. and Lois W. Hoffman. The employed mother in America. Chicago, Rand McNally, 1963. 406 p.

74. Oregon woman receives award. The Oregonian (Portland, Oregon) p. 12 col. 1,2. March 17, 1967.

75. Painter, Charlotte. The perfect day care home for Tommy. Ladies Home Journal 83:72. October 1966.

76. Parad, Howard J. (ed. ) Crisis intervention: Selected readings. New York, Family Service Association of America, 1965. $368 \mathrm{p}$.

77. Parsons, Talcott. Stability of the American family system. In: The Family, Norman W. Bell and Ezra F. Vogal (eds.) The Free Press of Glencoe, 1960. p. 93-97.

78. Perry, Joseph B. The mother substitutes of employed mothers: An exploratory inquiry. Marriage and Family Living 23:362-367. November 1961 . 
79. Peters, A. D. Day care--a summary report. American Journal of Public Health.54:1905-13. November 1964.

80. Planning services for children of employed mothers. U.S. Department of Labor. $62 \mathrm{p}$.

81. Polansky, Norman A. (ed.) Social work research. University of Chicago Press, Chicago and London, 1960. 306 p.

82. Prescott, Elizabeth. Pilot study of day care centers and their clientele. Children's Bureau, \#428. U.S. Government Printing Office, 1965. $40 \mathrm{p}$.

83. Robbins, J. and J. Robbins. One city that cares enough to make every mother's dream come true: Houston day care centers. Ladies Home Journal 83:71. July 1966.

84. Roemete, Victoria $\mathbf{S}$. Children's separation difficulties during diagnostic study. Smith College Studies in Social Work, Northampton, Mass. June 1965.

85. Ross, Sid. Who takes care of your children? Parade Magazine 18-21. March 5, 1967.

86. Ruderman, Florence A. Conceptualizing needs for day care. Some conclusions drawn from the Child Welfare League, D. D. project. Child Welfare, April 1965. Vol. 44, 207-213.

87. Day care: A challenge to social work. Child Welfare, 43. March 1964. p.117-123.

88. Day care and related facilities. Mimeo. Child Welfare League of America, 1965. 130 p.

89. Day care licensing report. Mimeo. Child Welfare League of America, $1965.68 \mathrm{p}$.

90. Schuessler, Karl F. A note on statistical significance of scalogram. Sociometry 24:312-318. 1961 .

91. Searls, L. G. Leisure role emphasis of college graduate homemakers. Journal of Marriage and the Family 28:77-82. February 1966. 
92. Seeman, Melvin. On the meaning of alienation. American Sociological Review 24, December 1959. p 783-791.

93. Seiden, Richard H. Salutary effects of maternal separation. Social Work, Vol. 10, No. 4, October 1965. p. 25-29.

94. Shaffer, Helen B. Editorial research report. Child day care and working mothers 2:481-98. July 1965 .

95. Sharp, Anne M. Observation of children in a day care center. Smith College Studies in Social. Work 36:54. October 1965.

96. Siegel, A. E. Health and day care for children of migrant workers. Public Health Report 79:847-52. October 1964.

97. Siegel, A. E., et al. Dependence and independence in the children of working mothers. Child Development 30:533-46. December 1959.

98. Spotlight on day care: Proceedings of the national conference on day care services, May 13-15, 1965. Children's Bureau, \#438, U.S. Government Printing Office, Washington, D. C. , 1966. $173 \mathrm{p}$.

99. Stewart, A. M. Strengthening family life: Mothers at work. Royal Society Health Journal 79:578-83. September-October, 1959.

100. Stolz, Lois Meek. Effects of maternal employment on children. Evidence from research. Child Development 31(4):749-782. December 1960.

101. Thibaut, John W. and Harold H. Kelley. The social psychology of groups. New York, Wiley, 1959. 313 p.

102. To do a man's job. (ed.) Economist 211:270. April 18, 1964.

103. Today's child: A tearnwork exploration in day care. Portland Community Council and Oregon State Public Welfare Commission. Proceedings of a workshop, Oct. 26-27, 1962.

Portland, Oregon. $52 \mathrm{p}$.

104. Tolstrup, K. Day care for children. WHO Chron. 18:363-8. October, 1964. 
105. Trout, Bessie E. and Dorothy E. Bradbury. Mothers for a day: History and background of the care of the children in families other than their own. Family Day Care. Children's Bureau, \#318, U.S. Government Printing Office, 1946. 39 p.

106. Underprivileged majority (working women). Economist 210:24. January 4, 1964.

107. Walton C. Child minders. New Statesman 70:1021-2. December 31, 1965.

108. What is good day care? Children's Bureau, U. S. Government Printing Office, 1964. $11 \mathrm{p}$.

109. Willner, Milton. Day care--a reassessment. Child Welfare, Vol. 44, No. 3, 125-133. March 1965.

110. Winston, Ellen. National need for day care programs. Commissioner of Welfare, Department H. E. W., to be delivered at Children's Bureau Day Care Conference, Washington, D. C. , March 19, 1964.

111. Wise, G. M. and D. C. Carter. Definition of role of homemaker by two generations of women. Journal of Marriage and the Family 27:531-2. November 1.965.

112. Women's work is never done: Problems of working mothers and wives. Free Labour World, May 1964. p. 7-11. 
APPENDICES 


\section{APPENDIX A}

\section{INTERVIEW SCHEDULE FOR MOTHERS}

\section{SECTION A: IDENTIFYING CHARACTERISTICS OF THE ARRANGEMENT}

1. Your name was given us by (The Welfare Department) (The Day Care Exchange Project) as someone who had had a day care arrangement with Mrs. , which you recently terminated. Is that correct? Was she taking care of a child for you? Yes No

2. How many children of yours was she taking care of?

3. How old were they and what grade were they in, if they were?

Dates of Arrangement (Item 4)

Name Age Grade Began Ended No. of Weeks

4. Can you tell me how long this day care, or babysitting, arrangement lasted--when it began and when it ended? (If two or more children were involved, get dates for each. If one child started with DCG before another, count the arrangement as beginning with the first child.)

Probe: Do you remember the dates: We need to know how many weeks or months Mrs. X took care of your child (children) in this last arrangement. I have a calendar here which might help--it's hard remembering dates.

5. In this arrangement, how many days in the week did she (Mrs.X) take care of ?

6. And for how long? How many hours a day?

7. What did you pay for day care?

- How did you arrive at the price:
(a) Mother's price
(b) Sitter's price
(c) Compromise 


\section{SECTION B: BEFORE THE ARRANGEMENT BEGAN}

8. Now, think back to before this day care arrangement began. How did you happen to find Mrs. X?

Probe: When did you meet her for the first time? How did you know she did child care?

9. Before the arrangement began, how long had you known each other?

10. By the time the arrangement began, would you say you two were more friends, acquaintances, or strangers?

11. Were you neighbors? Yes No Uncertain

12. How far away did you two live? How many blocks or how many miles.

Number of blocks ; Number of miles

13. Why did you choose to take your child out to someone's home rather than make some other kind of child care arrangement?

Code: (a) The preferred alternative

(b) "No choice" (no alternative seen)

Why?

14. When you were thinking about finding a babysitter, what did you look for in a sitter?

Probe: (a) Can you remember what was most important to you?

(b) What was next most important to you?

(c) Was there anything else of particular importance to you? 


\section{SECTION C: IN THE BEGINNING}

15. You hardly ever find exactly what you are looking for.

You have said you wanted:

(a) Yes No Partially

(b) Yes No Partially

(c) Yes No Partially
Did you have that in the arrangement with Mrs.

Did you have that in the arrangement with Mrs. ?

Did you have that in the arrangement with Mrs.

16. At the time Mrs. X started taking care of your children (child) were you working?

Probe: Already working? Or planning to work? Out looking for work? In a training program? Other?

17. In the beginning of this day care arrangement, just after Mrs. $\mathrm{X}$ started taking care of your children (child) were you satisfied with the arrangement you had made?

18. Was there anything you liked about it, back in the beginning?

19. Was there anything you didn't like about it, back in the beginning?

20. What about the babysitter--Mrs. X? Do you think she was satisfied or dissatisfied with the arrangement?

21. a) What do you think she liked about it?

b) What do you think she didn't like about it?

22. In the beginning, for how long did you expect to have Mrs. X taking care of your children? 


\section{SECTION D: DID ANYTHING CHANGE?}

Now we would like to know if anything changed in the way you felt about your arrangement with Mrs. X.

23. In general, all things considered, would you say you became better satisfied or less satisfied with the arrangement?

24. Did you become dissatisfied in any way? Yes No If so, in what ways?

25. In what ways, if any, were you happier or more satisfied with the arrangement?

26. As time went on, did the children get along better or worse, or the same?

27. As time went on, did the whole arrangement seem more convenient or less convenient or the same?

28. As time went on, did you like Mrs. X better or worse or the same?

29. As time went on, did you like working, or whatever you were doing, better or worse or the same?

30. We would like to know how you keep a babysitting arrangement from falling apart. What does it take to keep a babysitting arrangement going? (Emphasis on maintenance behavior and attitude).

31. One of the big worries of working mothers is what to do when your children get sick. Did your child ever get sick during the time we have been talking about? Yes No

If yes, 31 (a) What did you do for child care?

Stayed home?

Had somebody come in?. Who?

Took child to sitter as usual?

What else?

If no, 31 (b) What would you have done for child care?

Stayed home?

Took child to sitter as usual?

Had somebody come in? Who?

What else? 
SECTION E: TERMINATION OF ARRANGEMENT

32. Now we would like to know what happened to this arrangement. Why was it ended or terminated? Why did you stop taking your children to Mrs. $\mathrm{X}$ for day care?

33. Whose idea was it to terminate the arrangement?

Probe: Yours? Sitters? Husbands? Sitter's husband?

$$
\text { Employer? Child's? }
$$

34. Did you change because you were dissatisfied in any way or was it for some other reason?

35. Would you have Mrs. X take care of your children (child) again? Yes No It depends on 
SECTION F: CHANGE TO WHAT?

36. What did you change to? What is your present child care arrangement?

37. Are you working now? Or what?

\section{SECTION G: PRESENTATION OF CARDS}

Now I would like to get your reaction to a number of statements I am going to show you on cards; and I want you to say whether you agree or disagree. All these statements are about this last babysitting arrangement you had with Mrs. X and what you thought of it. I'll read the card, give it to you and you put it in one of these four places depending on whether you strongly agree, agree, disagree or strongly disagree (Present LAS items).

(Before presenting the Mother's Role Satisfaction cards and the Mother's Role Dependence cards advise respondent of change in focus.)

Do you have any comments you would like to make? 
SECTION H: BACKGROUND DATA

$$
\text { Mrs. }
$$
, you have been very good at

answering some difficult questions. I just have one or two more factual questions to ask you for background information.

38. Do you have any other children, and if so, what are their names, ages and grade.
NAME
$\underline{A G E}$
GRADE

39. Was the babysitting arrangement we have been talking about the first one for (Johnny and Mary)? How many previous sitters had you made arrangements with before for him (her, them)?

40. All together, for any and all children, how many child care arrangements do you think you have made?

41. How long have you worked? How many years or months?

\section{Continuously?}

42. What is your job?

43. Are you trained for any particular jobs? Yes No What jobs?

44. What was the last year you completed in school?

45. Who else lives in your household? 
46. We would like to know how much your salary or wages contributes to your total family income. Look at this card and tell me what your income was (show card).

47. How much did you make last month? (gross)

48. How much did the whole family make last month? (gross)

49. How much did you think you made in 1965? (gross)

50. How much did the whole family make in 1965? (gross)

\section{INCOME SCHEDULE}

\begin{tabular}{|c|c|c|c|}
\hline Code & Annual Income & Monthly Income & Weekly Income \\
\hline 1 & less than $\$ 1,000$ & less than $\$ 83$ & less than $\$ 19$ \\
\hline 2 & $\$ 1,000$ to $\$ 1,999$ & $\$ 83$ to $\$ 166$ & $\$ 19$ to $\$ 37$ \\
\hline 3 & $\$ 2,000$ to $\$ 2,999$ & $\$ 167$ to $\$ 249$ & $\$ 38$ to $\$ 57$ \\
\hline 4 & $\$ 3,000$ to $\$ 3,999$ & $\$ 250$ to $\$ 332$ & $\$ 58$ to $\$ 76$ \\
\hline 5 & $\$ 4,000$ to $\$ 4,999$ & $\$ 333$ to $\$ 416$ & $\$ 77$ to $\$ 95$ \\
\hline 6 & $\$ 5,000$ to $\$ 5,999$ & $\$ 417$ to $\$ 499$ & $\$ 96$ to $\$ 114$ \\
\hline 7 & $\$ 6,000$ to $\$ 7,999$ & $\$ 500$ to $\$ 666$ & $\$ 115$ to $\$ 153$ \\
\hline 8 & $\$ 8,000$ to $\$ 9,999$ & $\$ 667$ to $\$ 832$ & $\$ 154$ to $\$ 191$ \\
\hline 9 & $\$ 10,000$ to $\$ 14,999$ & $\$ 833$ to $\$ 1,249$ & $\$ 192$ to $\$ 288$ \\
\hline 0 & $\$ 15,000$ or over & $\$ 1,250$ or over & $\$ 289$ or over \\
\hline
\end{tabular}


APPENDIX B

INTERVIEW SCHEDULE FOR SITTERS

\section{SECTION A: IDENTIFYING CHARACTERISTICS OF THE ARRANGEMENT}

1. Your name was given to us by as someone mother's name who had recently given day care for her child/children. We understand the babysitting arrangement was recently terminated. Is that correct? Yes No

2. How many children of hers were you taking care of?

3. Which child/children of hers did you care for?

Name Age Dates of Arrangement

Began Ended No. of weeks

4. Can you tell me how long this day care or babysitting arrangement lasted? When did it begin and when did it end? (If two or more children were involved, get dates for each. If one child started with sitter before another, count the arrangement as beginning with the first child.)

Probe: We need to know how many weeks or months you took care of Mrs. X's child/children. Offer calendar.

5. In this arrangement, how many days in the week did you take care of ?

child's name

6. And for how long? How many hours a day?

7. How did you arrive at the price she paid you?
(a) Mother's Price
(b) Sitter's Price
(c) Compromise What did she pay you for day care? 
SECTION B: BEFORE THE ARRANGEMENT BEGAN

8. Now, think back to before this day care arrangement began. How did happen to find you or know mother's name

that you did babysitting?

9. Before the arrangement began, how long had you two known each other?

10. Before the arrangement began, would you say you two were: friends, acquaintances or strangers?

11. Were you neighbors: Yes No Uncertain

12. How far away did you two live? How many blocks or how many miles?

13. When you thought about babysitting, what did you look for in the mothers and children, in deciding whether to sit for them or not?

\section{Probes:}

(a) Can you remember what was most important to you?

(b) What was next most impor tant to you?

(c) Was there anything else of particular importance to you? 


\section{SECTION C: IN THE BEGINNING}

14. You hardly ever find exactly what you are looking for.

You have said you wanted:

(a)

Yes No Partially

Did you have that in the arrangement with

(b)

Yes No Partially

(c)

Yes No Partially

Did you have that in the arrangement with

mother's name

Did you have that in the arrangement with

mother's name

15. At the time you started taking care of mother's name child/children, were you taking care of other children or what were you doing?

Probe: Had you ever cared for children before for pay?

16. In the beginning of this day care arrangement, just after you started taking care of mother's name 's children, were you satisfied with the whole arrangement?

(If satisfied, ask $17 \mathrm{a}$, if dissatisfied, ask $17 \mathrm{~b}$ )

17. a) Was there anything you liked about it back in the beginning?

b) What didn't you like about it back in the beginning?

18. What about the mother, Mrs. ? Do you think she was satisfied or dissatisfied with the arrangement?

19. a) What do you think she liked about it?

b) What do you think she didn't like about it?

20. In the beginning, how long did you expect to care for Mrs. child/children? 


\section{SECTION D: DID ANYTHING CHANGE?}

21. Now we would like to know if anything changed in the way you felt about your arrangement with Mrs.

mother's name

22. In general, all things considered, would you say you became better satisfied or less satisfied with the arrangement?

23. Did you become dissatisfied in any way? Yes No If so, in what ways?

24. In what ways, if any, were you happier or more satisfied with the arrangement?

25. As time went on, did the children get along better or worse, or the same?

26. As time went on, did the whole arrangement seem more convenient or less convenient or the same?

27. As time went on, did you like Mrs. X (mother) better or worse or the same?

28. As time went on, did you like babysitting for Mrs. X children better or worse or the same?

29. And what does it take to keep a babysitting arrangement going? (Emphasis on maintenance behavior and attitude) 


\section{SECTION E: TERMINATION OF ARRANGEMENT}

30. Now we would like to know what happened to this arrangement. Why was it ended or terminated? Why did you stop taking care of Mrs. X's children?

31. Whose idea was it to terminate the arrangement?

Probe: Mother's

Sitter's

Sitter's husband

32. Was the arrangement ended because you were dissatisfied in any way or was it for some other reason?

33. Would you take care of Mrs. X's children (child) again?

Yes No It depends on

\section{SECTION F: CHANGE TO WHAT?}

34. When you quit taking care of Mrs. X's children, what did you do them?

$$
\begin{aligned}
& \text { Take in other children? } \\
& \text { Quit giving day care? }
\end{aligned}
$$

35. Are you babysitting now? Or what?

\section{SECTION G: PRESENTATION OF CARDS}

Now I would like to get your reaction to a number of statements I am going to show you on cards; and I want you to say whether you agree or disagree. All these statements are about this last day care arrangement you had with Mrs. X, and what you thought of it. I'll read the card, give it to you and you put it in one of these four places depending on whether you strongly agree, agree, disagree or strongly disagree. (Present LAS cards. Follow with RD and RS cards. Alert respondent to change in focus.)

Do you have any comments you would like to make? 
SECTION H: BACKGROUND DATA

Mrs. , you have been very good at

answering some difficult questions. I just have one or two more factual questions to ask you for background information.

36. Do you have any children, and if so, what are their names, ages, and grade in school.
$\underline{\text { Name }}$
$\underline{\text { Age }}$
Grade

37. All together, how many children have you taken care of on a regular basis?

In the home?

Outside in others' homes?

38. How long have you been doing babysitting? How many years months? Continuously?

We would like to know some of the reasons you do babysitting.

39. Have you ever worked outside the home other than babysitting?

40. Are you trained for any particular job? Yes No What jobs?

41. What was the highest grade you completed in school?

42. Who else lives in your household?

$\underline{\text { Name }} \quad \underline{\text { Relationship }}$ Occupation

43. We would like to know how much the money you make from babysitting contributes to your total family income. Look at this card and tell me what your income was (show card). 
44. How much did you make last month? (gross)

45. How much did the whole family make last month? (gross)

\section{INCOME SCHEDU LE}

$\begin{array}{llll}\text { Code } & \text { Annual Income } & \text { Monthly Income } & \text { Weekly Income } \\ 1 & \text { less than } \$ 1,000 & \text { les s than } \$ 83 & \text { les than } \$ 19 \\ 3 & \$ 1,000 \text { to } \$ 1,999 & \$ 83 \text { to } \$ 166 & \$ 19 \text { to } \$ 37 \\ 4 & \$ 2,000 \text { to } \$ 2,999 & \$ 167 \text { to } \$ 249 & \$ 38 \text { to } \$ 57 \\ 5 & \$ 3,000 \text { to } \$ 3,999 & \$ 250 \text { to } \$ 332 & \$ 58 \text { to } \$ 76 \\ 6 & \$ 4,000 \text { to } \$ 4,999 & \$ 333 \text { to } \$ 416 & \$ 77 \text { to } \$ 95 \\ 7 & \$ 5,000 \text { to } \$ 5,999 & \$ 417 \text { to } \$ 499 & \$ 96 \text { to } \$ 114 \\ 8 & \$ 6,000 \text { to } \$ 7,999 & \$ 500 \text { to } \$ 666 & \$ 115 \text { to } \$ 153 \\ 9 & \$ 8,000 \text { to } \$ 9,999 & \$ 667 \text { to } \$ 832 & \$ 154 \text { to } \$ 191 \\ 0 & \$ 10,000 \text { to } \$ 14,999 & \$ 833 \text { to } \$ 1,249 & \$ 192 \text { to } \$ 288 \\ & \$ 15,000 \text { or over } & \$ 1,250 \text { or over } & \$ 289 \text { or over }\end{array}$




\section{APPENDIX C}

\section{MOTHER'S CARD ITEMS IN ORDER OF PRESENTATION}

LAS ti 1. The babysitter and I enjoyed getting together.

LAS - 2. I wasn't satisfied with the kind of neighborhood.

LAS - 3. We were too different in the way we brought up children.

LAS + 4. I was satisfied with her housekeeping and the way she kept the children clean.

LAS + 5. She gave the children enough to do.

LAS - 6. I had trouble with my children (child) because the sitter spoiled them.

LAS + 7. She took a real interest in my child (children).

LAS + 8. I liked the way she trained my child (children).

LAS + 9. Her friendship meant a lot to me.

LAS + 10. She went out of her way to help me.

LAS - 11. I didn't like the way she tried to tell me what to do.

LAS - 12. My last sitter charged too much.

LAS + 13. We had a lot in common.

LAS +14 . I would be willing to use the same sitter again.

LAS - 15. I don't think she approved my working.

LAS + 16. My children (child) learned some important things that they wouldn't have gotten at home.

I.AS + 17. She took an interest in me personally.

IuAS - 18. I wasn't satisfied with the house and yard. 
LAS + 19. I like the way she treats children.

LAS - 20. The sitter wouldn't tell me what went on with the children.

LAS - 21. She expected too much of me.

LAS + 22. My sitter and I kept on pretty good terms.

LAS - 23. The baby sitter lived too far away to be convenient.

LAS - 24. I felt she took advantage of me.

LAS + 25. If I ever had to change my plans, she was very flexible about it.

LAS - 26. As time went on, I started looking for a better arrangement with another sitter.

LAS - 27. I don't think she gave the children enough attention.

LAS - 28. I got tired of her telling me her problems.

LAS + 29. My sitter really did more for me than she had to.

LAS - 30. I didn't like the other children who were in the babysitter's home.

LAS - 31. I couldn't count on her to help out in an emergency.

LAS - 32. It was hard trying to discuss my child (children) with the babysitter.

LAS + 33. She was the sort of person you could tell your problems to.

RS + 34. I get criticized if I don't work.

RS - 35. I worry about whether my working is good for my child (children).

RS - 36. I really would prefer to stay home myself.

RD + 37. A good babysitter is hard to find. 
RD + 38. My job depends on having a babysitter.

$\mathrm{RD}+$ 39. I leave my child (children) with a babysitter because I don't have any choice.

$\mathrm{RD}+40$. I feel like almost everything depends on being able to make a good day care arrangement for my child (children).

RS +41 . I like the daily routine of going to work.

RS + 42. Babysitters deserve a lot of credit.

RS - 43. It bothers me not knowing what goes on with the children when they are at the sitter's.

RS - 44. It's hard to know what you can expect of a sitter.

RD - 45. My children get along with anybody.

RS - 46. It bothers me that I can't have the kind of child care arrangement I would really like.

RS - 47. I have been criticized more than once for being a working mother.

RS - 48. I get criticized for leaving my child with a babysitter.

RS - 49. I would rather have my child at a day care center than at the home of a sitter.

RD - 50. I never have to worry about finding another sitter.

RS . + 51. I am appreciated more at home when I am working.

RS - 52. My neighbors don't approve of my working.

$R D+53$. The money I make is important to me.

$\mathrm{RS}+54$. I would rather leave my child with a sitter than with a relative or a member of my own family.

RS + 55. Children learn a lot from staying in someone else's home during the day. 
RS + 56. I am happier when I am working.

RS - 57. I worry about whether babysitting is good for my children (child).

$R D+58$. I work in order to get ahead.

RS + 59. When I work, I'm better organized at home.

RS +60 . I get a better idea of what my children are like from talking to the babysitter.

RS - 61. I wish I didn't have to work.

RS - 62. My family would rather have me stay at home.

$R D+63$. I'm careful not to impose on my babysitter.

$R D+64$. Getting someone really reliable is very difficult.

RS - 65. I worry about leaving my child with a sitter.

RD - 66. The most important thing about a day care arrangement is whether your child takes to the sitter.

$\mathrm{RD}+67$. I make every effort to patch up misunderstandings with the sitter.

RS - 68. It's hard trying to hold down a job and raise children at the same time.

RS - 69. My children are harder to handle since they have been. going to babysitters.

RS +70 . You usually can trust a sitter to do a good job.'

RD - 71. If necessary, I could quit work and stay home.

RD - 72. Paying for child care costs so much that it's hardly worth my working.

RS + 73. I feel more important when I am working.

RS +74 . Having a job is better than being just a housewife. 
RS - 75. I would rather have a babysitter come into my own home than have my children go out.

RS + 76. On the whole, I think I can be a better mother if I work.

$R D+77$. You really have to work at it if you want to keep the sitter happy.

RD - 78. I want my children to have the experience of being with different sitters.

RS + 79. My family seems to get along better at home when I am working.

RD - 80. The sitter has to be flexible because sometimes I can't get there on time.

RD - 81. I don't want my child to get too attached to a sitter.

RD - 82. If my child did not like the sitter, I would change.

RS + 83. I enjoy getting away from hous ework.

RS - 84. Mothers shouldn't work unless they absolutely have to.

RD - 85. I have a neighbor or relative who is available in an emergency.

$\mathrm{RD}+86$. I hate having to change sitters.

RD - 87. I could work a different shift and do without a sitter altogether.

RS + 88. Working keeps me from feeling bored.

RD - 89. My working hours are flexible, and I can arrange them to suit my child care plans.

$R D+90$. I simply can't afford to lose my job.

RD - 91. When my child (children) is sick, I am able to stay home.

RD + 92. My family couldn't get by if I didn't work. 
RD - 93. I can always get a sitter through an agency.

$\mathrm{RD}+94$. I have to work in order to make ends meet.

RD + 95. If I want a sitter, I have to take what I can get.

RD - 96. I have a list of alternates if this arrangement fails.

RS - 97. In general, I'm not in favor of mothers working.

$R D+98$. I worry about being able to keep a babysitter after I get her.

$\mathrm{RD}=$ Mother's role dependence

LAS $=$ Mother's satisfaction with last babysitting arrangement

RS = Mother's role satisfaction in role of working mother and user of private family day care 
APPENDIX D

\section{SITTER'S CARD ITEMS IN ORDER OF PRESENTATION}

LAS +1 . She took a real interest in her child (children).

LAS - 2. I was really ready to give the children up.

LAS + 3. I like the way the mother treats children.

LAS - 4. I had trouble with her children (child) because they were spoiled.

LAS - 5. I worried about whether the mother thought I was doing all right.

LAS - 6. The mother expected too much from me.

LAS - 7. I really did more for the mother than I had to.

LAS + 8. The mother's friendship meant a lot to me.

LAS + 9. The mother took an interest in me personally.

LAS + 10. I was sorry to see the children go.

LAS +11 . The mother and I had a lot in common.

LAS + 12. The children hated to leave me.

LAS + 13. The mother and I enjoyed getting together.

LAS - 14. The children weren't happy here.

LAS +15 . The mother really cared how I felt about things.

LAS - 16. I felt like the mother took advantage of me.

LAS +17 . The children were neat and clean.

LAS - 18. I don't think the mother gave her children enough attention. 
LAS - 19. The mother didn't think much of people who give child care.

LAS +20 . I would sit for the mother again if she asked me.

LAS - 21. I became less satisfied with the mother.

LAS +22 . I would be willing to take her child again.

LAS - 23. The mother and I were too different in the way we bring up children.

LAS - 24. The mother didn't pay me enough.

LAS +25 . The mother and I kept on pretty good terms.

LAS +26 . I was satisfied with the money.

LAS - 27. I don't think the mother approved of me.

IuAS - 28. The children were too much for me.

IuAS + 29. I was satisfied with the hours I took care of the child.

LAS + 30. I liked the way her children behaved.

LAS - 31. I don't think the mother was concerned enough about her children.

LAS - 32. I got tired of the mother telling me her problems.

LAS + 33. The mother was the sort of person you could tell your problems to.

LAS - 34. I became less satisfied with the children.

LAS - 34a. It was hard trying to discuss her child (children) with her.

RD + 35. If I want to do babysitting, I have to take what I can get.

RD +36 . I can get along with any child.

RD + 37. There are a lot of women in my neighborhood who take care of children. 
RD - 38. I won't keep on caring for a child if the mother isn't reliable about paying.

RS + 39. Children learn a lot from staying in someone else's home during the day.

RS - 40. Mothers tend to impose on sittexs.

RS + 41. I like comparing my children with other people's children.

RD - 42. I am not particular about the seace of children I care for.

RD - 43. I try to have children who will stay a long time.

$\mathrm{RD}+44$. I have never asked for a child's removal.

$R D+45$. I am not particular about the sex of children I care for.

RS + 46. I like helping out children of working mothers.

RS - 47. My husband (or family) doesn't approve of my babysitting.

RS + 48. I get a lot of satisfaction out of seeing children grow up.

$R D+49$. I am not particular about the ages of children I care for.

RS - 50. Sometimes mothers say they will bring their children and they don't show up.

RS + 51. My day care children appreciate me more than my own children do.

RS + 52. Child care is one of the most important jobs a woman can have.

RS - 53. Sometimes I worry whether I'm doing a good job as a sitter.

RS - 54. Mothers shouldn't work unless they absolutely have to. 
RS + 55. I am appreciated more at home because I give child care.

RS - 56. I get too attached to the children.

RD - 57. I won't care for a child if I don't get along with the mother.

RS + 58. I would rather do babysitting than go out to work.

RS - 59. It's hard to get the children to behave because the mothers don't follow through at home.

RS - 60. I feel criticized for doing babysitting.

RD - 61. I don't like to keep the same children too long.

RS +62 . I'm happier when I am taking care of children.

RS + 63. It's easier to take care of other people's children. than it is your own.

$R D+64$. Onice I take a child, I'Il keep him as long as I'm asked to.

RD - 65. Working mothers have a hard time getting good sitters.

RD - 66. I would not want to care for a handicapped child.

RS +67 . Being a babysitter makes me feel I'm doing something worthwhile.

RS - 68. Mothers sometimes aren't very reliable about paying me.

RS - 69. I don't like to admit to people that I do babysitting.

RS + 70. My own children think it's fun to have other children around.

RS - 71. I'd rather have some other job than babysitting.

RS + 72. My neighbors approve of my doing babysitting. 
$\mathrm{RD}+73$. One reason I need to do babysitting is so my child will have other children to play with.

RS + 74. I get a lot of satisfaction out of taking care of children.

$R D+75$. If I didn't do babysitting, I don't know what I'd do to make money.

RD - 76. I would not keep a child who doesn't get along here.

RD + 77. There is a big demand for babysitters in my neighborhood.

$R D+78$. I take children whether they are sick or not.

$R D+79$. I could not take care of children of another race in this neighborhood.

RS - 80. Children get too attached to me.

RD + 81. I would like to take care of more children than I have.

RS + 82. I like helping out mothers who work.

RD - 83. I can afford to be choosy about whom I sit for, because sitters are hard to find.

$R D+84$. I do babysitting because I don't have any other choice.

$R D+85$. Babysitting gives me my own spending money.

RS - 86. My own children pick up bad habits from the day care children.

RS - 87. Almost everybody knows that I do babysitting.

$\mathrm{RD}+$ 88. I try to keep at least a few children all the time.

RS - 89. I'm not really satisfied with the amount of money I can make babysitting.

RS - 90. If I weren't doing babysitting, I'd get bored.

RS + 91. I have a nice house and yard for taking care of other people's children. 
RD - 92. I don't want to get too attached to the children I take.

RS + 93. I'm all in favor of mothers working.

RD - 94. I would refuse to babysit for some people.

$R D+95$. Babysitting money provides some "extras" for my family.

RS + 96. I would feel lost if I didn't have any children around.

RS - 97. My husband (or family) would prefer that I went out to work instead of babysitting.

RD - 98. I do babysitting even though I don't especially need the money.

RS + 99. One of the nice things about doing babysitting is getting to know the mothers.

RD +100. I usually have a waiting list of mothers who want me to keep their children.

LAS = Day Care Giver's satisfaction with last arrangement

RS = Day Care Giver's role satisfaction

RD = Day Care Giver's role dependence 
APPENDIX E

LETTER SENT TO SAMPLE

PORTLAND STATE COLLEGE

P. O. BOX 751 PORTLAND, OREGON 97207

SCHOOL OF SOCIAL WORK

$226-7271$

Dear

The school of Social Work at Portland State College is conducting a research study regarding the child care arrangements of working mothers. We will be interviewing both the mothers and the pexsons who took care of their children.

Your name was given to us by as someone who recently had experience with a child care arrangement. We would like to have a personal interview with you, which would last about 45 minutes. We will be contacting you in the near future to arrange an appointment to see you at a time and place of your convenience.

We sincerely appreciate the help of all the mothers and "sitters" who have agreed to participate in our study.

I am looking forward to meeting with you.

Sincerely,

Research Interviewer 